$$
\text { UNIVERSIDADE DE SÃO PAULO }
$$

FACULDADE DE FILOSOFIA, LETRAS E CIÊNCIAS HUMANAS DEPARTAMENTO DE LETRAS ORIENTAIS

PROGRAMA DE PÓS-GRADUAÇÃO EM ESTUDOS JUDAICOS E ÁRABES

\title{
Lugares incertos: os andarilhos de Samuel Rawet
}

\author{
Leo Agapejev de Andrade
}

Tese de doutorado apresentada ao Programa de Pós-Graduação em Estudo Judaicos e Árabes do Departamento de Letras Orientais da Faculdade de Filosofia, Letras e Ciências Humanas da Universidade de São Paulo, para a obtenção do grau de doutor em Letras, Área de Concentração Estudos Judaicos.

Orientadora: Profa. Dra. Berta Waldman

\section{São Paulo}




\section{Agradecimentos}

Ao prof. dr. Saul Kirschbaum, pela paciência e minúcia ao coorientar este trabalho nas fases iniciais.

À Capes, pela bolsa concedida.

Ao Billy, Jovelina, Michelangelo e Violeta, pela companhia. 
It was an illusory place that existed in my head, and that's where I was as well. In both places at the same time. In the apartment and in the story. In the story in the apartment that I was still writing in my head.

(Paul Auster, Oracle night)

- Estar numa cidade não é a mesma coisa que entrar nela, Mateo. Por exemplo, você e eu em nosso hotel. Estamos em Buenos Aires, mas não estamos. No apartamento da Deán Funes eu estava em Buenos Aires, mas não estava de todo. Em compensação, na Coronda, sim, Coronda era enfim Buenos Aires, por dentro da cidade, como se diz, no coração da cidade. E olhe, não acho que seja uma metáfora; Caballito está no centro de Buenos Aires e Coronda deve estar no centro de Caballito. Ou, quem sabe, isso já seja literatura.

(Laura Restrepo, Herois demais) 
Resumo: A escrita de Samuel Rawet é formada por peculiaridades que demandam um leitor atento e crítico quanto à forma de abordagem e interpretação do texto, de maneira que suas "linhas de força" (Waldman, 2004) sejam entrevistas como potencialidades de sentidos. O lugar-comum rawetiano, conceito inevitavelmente impreciso formulado a partir dos contos analisados, mostra ser uma forma de abordagem frutífera e coerente ao texto rawetiano em geral, ao privilegiar elementos textuais e se juntar a outras abordagens à obra de Rawet, trazendo questões como identidade, alteridade, literatura judaica e autoria, dentre outras. Como pontos de partida problematizantes são tomados a figura de Ahasverus em "Crônica de um vagabundo", a estrutura aberta e a metalinguagem em "Kelevim", o conto dentro do conto em "Reinvenção de Lázaro", e o sonho em "Sôbolos rios que vão". Algumas dessas questões permeiam mais de um dos contos, como a autoria ("Crônica...", "Sobolos...", "Kelevim"). A estrutura aberta de "Kelevim", por sua vez, permite análises comparativas com o ensaio-crônica "Diário de um candango", sobre o livro de memórias de Marques da Silva, que leva o mesmo título. Ao final, as linhas de força são seguidas ainda mais longe, e arrisca-se uma rápida aproximação com as artes plásticas que conclui este trabalho com uma abertura que atesta a riqueza e validade da obra de Rawet.

Palavras-chave: lugar-comum, "linhas de força", biografia, identidade, alteridade, literatura judaica, autoria. 


\begin{abstract}
The writing of Samuel Rawet consists of peculiarities that demand a careful and critical reader who could approach to and interpretate his writings, in order to realize its "lines of force" (Waldman, 2004) as potential paths of meanings. The rawetian commonplace, inevitably imprecise concept formulated from the short stories analyzed, shows a fruitful and coherent approach to rawetian text, privileging the textual elements and joinning to the other approaches to Rawet's work, bringing up issues like identity, otherness, Jewish literature and authorship, among others. As controversial themes, I focus on Ahasverus in "Chronicle of a tramp", the open structure and metalanguage in "Kelevim", the story within the story on "Reinvention of Lazarus," and dream on "Over the flowing rivers". Some of these issues goes along more than one story, such as authorship ("Chronicle", "Over...","Kelevim"). The open structure of "Kelevim", on the other hand, allows comparative analyzes with the chronicle-essay "Diary of a candango", about the same-titled memoirs of Marques da Silva. Finally, the "lines of foces" are followed even further, and I dare a quick approximation to the visual arts that ends this thesis with an aperture that attests the wealthy and valuable works by Rawet.
\end{abstract}

Keywords: commonplace, "lines of force", biography, identity, otherness, Jewish literature, authorship. 


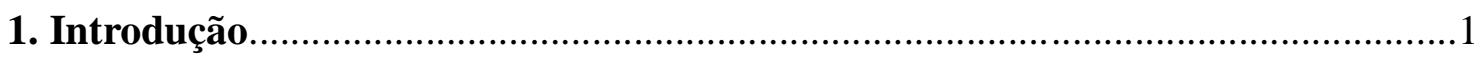

2. Fortuna crítica

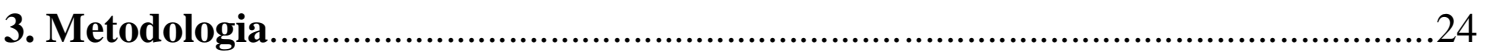

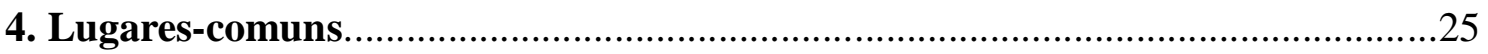

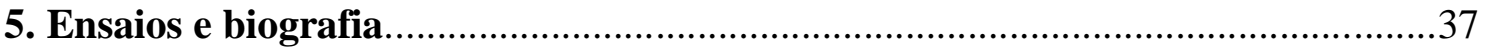

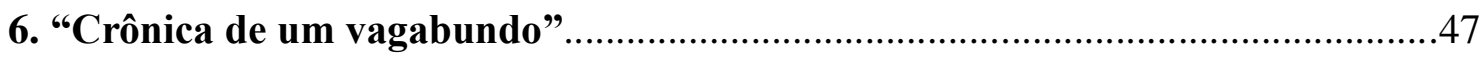

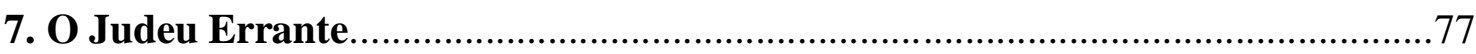

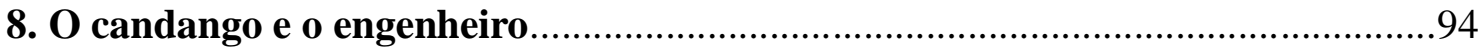

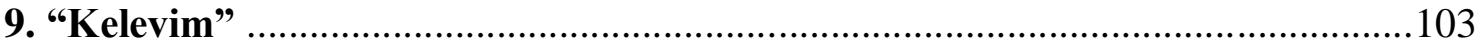

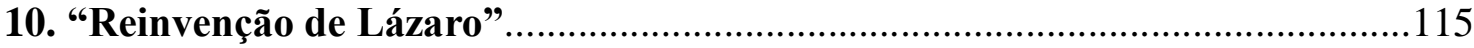

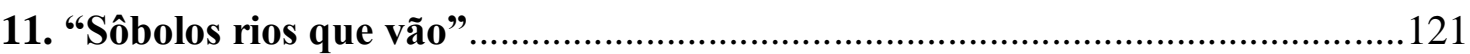

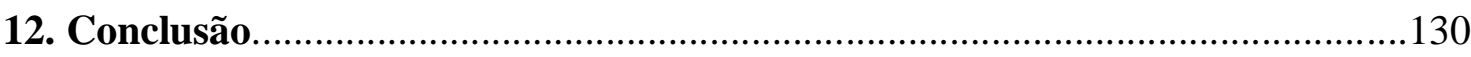

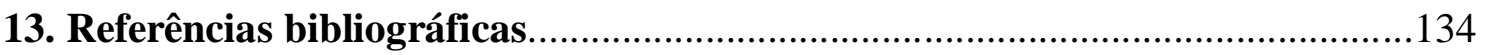

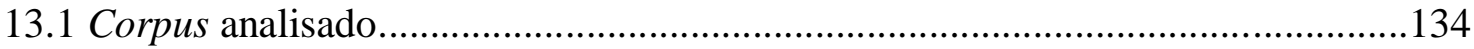

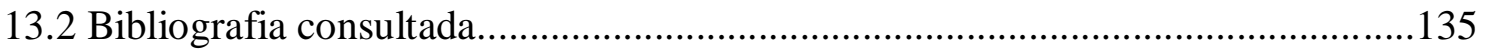

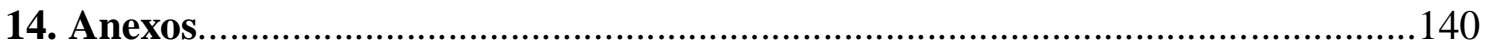

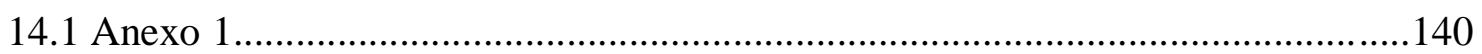

14.2 Anexo 2 - Subnúcleos de “Crônica de um vagabundo"”......................................143 


\section{Introdução}

O programa de Estudos judaicos da USP está inserido no departamento de Letras Orientais, junto aos programas de russo, japonês, chinês, coreano e árabe, ao qual se juntou recentemente. Nessa diversidade cultural enorme estão englobadas literaturas diversas que não estão apartadas das literaturas ocidentais de línguas modernas, como a alemã. A incômoda imprecisão da classificação persiste quando se fala, no âmbito literário do Programa de Estudos judaicos, em literatura judaica: necessariamente hifenizada, híbrida, sem padrões nem modelos claramente definidos de temas e formas, encontra-se diluída pelos campos literários "alheios", estes sim confundidos com identidades territoriais e culturais conflituosas, é verdade, mas convencionalmente definidas e estabelecidas historicamente segundo jogos de força políticos. Em suma, advogam-se autonomias para as literaturas nacionais modernas que a chamada literatura judaica não advoga para $\mathrm{si}^{1}$ - daí a diferenciação entre literatura hebraica moderna (israelense ${ }^{2}$ ) e literatura judaica.

Temas da história e da cultura asquenazita são estabelecidos no Brasil de Moacyr Scliar; em contrapartida, maneiras diversas de se lidar com a própria origem judaica estão presentes em Rawet, e posteriormente em outros autores como Bernardo Ajzenberg. Diante desses rápidos exemplos, percebe-se a complexidade histórica e cultural própria da literatura abordada nos programas de graduação e pós-graduação em Estudos judaicos desse eclético Departamento de Letras Orientais ${ }^{3}$.

Nesse contexto, Samuel Rawet tem um lugar peculiar, híbrido de imigrante judeu (cujas marcas estão presentes em Contos do imigrante, de 1956, e obras posteriores, em menor grau) e autor nacional familiarizado com a linguagem popular e o espaço urbano do Rio de Janeiro, de Os sete sonhos (1967) e O terreno de uma polegada quadrada (1969), volumes nos quais os contos aqui trabalhados estão inseridos. Rawet será, então, estudado simplesmente como autor de literatura brasileira, uma vez que o enfoque desta tese não será problematizar a denominação "literatura judaica", embora inevitavelmente passe por isso, posto que não sejam categorias estanques.

\footnotetext{
${ }^{1} \mathrm{O}$ estudo de autores de cânones nacionais distintos, como Bruno Schulz e Joseph Roth, agrupados nas literaturas polonesa e alemã, respectivamente, tende a minimizar o contexto cultural comum, poliglota e judaico, desses dois galicianos relativamente contemporâneos de cultura germânica habsburga.

${ }^{2}$ A literatura israelense comporta, em menor número, obras escritas em árabe, e árabes que escrevem em hebraico.

${ }^{3}$ É claro que Rawet e Ajzenberg caberiam perfeitamente num programa universitário dedicado unicamente à literatura brasileira.
} 
Em Orientalismo, Edward Said, referindo-se a uma citação de Gramsci ${ }^{4}$, menciona que "Muito do investimento pessoal neste estudo [o texto é o prefácio à edição de 2003 de Orientalismo] deriva da minha consciência de ser um 'oriental', por ter sido uma criança que cresceu em duas colônias britânicas [Palestina e Egito, além dos EUA].” Por isso, diz, "o meu estudo do Orientalismo foi uma tentativa de inventariar em mim o sujeito oriental, os traços da cultura cuja dominação tem sido um fator tão poderoso na vida de todos os orientais" (2010, p. 57).

Said coloca-se como um oriental, tomando para si a denominação dada por europeus a não-europeus natos, com toda a complexidade que isso possa trazer. Pode-se dizer, então, que o autor toma para si - criticamente - o rótulo que lhe foi imposto no contexto onde nasceu e cresceu como um "estigma" que o acompanharia a vida toda. Partindo do olhar do dominador, olha para si mesmo não como um reflexo, isto é, como uma imagem nítida, mas como o produto do olhar alheio, distante e deformador, construído por palavras e ideologias: "Eu" (diria Said), o oriental, olho para outros como eu (os orientais) com os termos e linguagem que usam para nos descrever, não para corroborar estereótipos ou consensos mascaradores de complexidades, mas de modo a implodir a estrutura homogeneizante do olhar "deles" sobre "nós"; dobro-me sobre mim mesmo e, como oriental (i.e, pela linguagem "deles") descubro-me como sujeito, num inventário que busca a memória de si e das palavras.

Nos termos de Said, o olhar crítico sobre formas homogeneizantes (imagens, termos, consensos, senso comum e lugares-comuns) desestabilizaria as estruturas sobre as quais se erguem e se interligam essas formas ${ }^{5}$. Mas só assim o sujeito escondido e sufocado por essa crosta de imagens e conceitos torna à superfície, onde não é necessariamente um heroi, mas um sujeito comum; ou um anti-heroi, como o andarilho de "Crônicas de um vagabundo", conto a ser trabalhado nesta tese. Entretanto, só um leitor crítico pode percorrer um texto sem concessões como é o de Rawet. Portanto, o leitor deve estar atento para os questionamentos suscitados por esse movimento textual de dobrar-se sobre si mesmo.

\footnotetext{
4 A citação de Gramsci, de Cadernos do cárcere, é a seguinte: "O ponto de partida da elaboração crítica é a consciência do que você é realmente, é o ‘conhece-te a ti mesmo’ como um produto do processo histórico até aquele momento, o qual depositou em você uma infinidade de traços, sem deixar um inventário [...] portanto, é imperativo no início compilar esse inventário" (Gramsci apud Said, 2010, p. 56-57).

${ }^{5}$ A instalação de Cornelia Parker (cf. anexo) ilustra o processo desse olhar crítico: uma cabana explodida sempre será uma cabana - despedaçada.
} 
Crítica, memória e identidade são palavras recorrentes nas entrelinhas dos contos de Samuel Rawet, escritor que exige um leitor também participativo.

Diante dessa exigência do texto, vista como imperativa por Said, creio que caiba nesta Introdução um inventário pessoal do sujeito que escreve este trabalho, despertado pelo diálogo com o texto rawetiano, por meio da figura do andarilho. Isso posto, inicialmente, à maneira de Edward Said, busco esclarecer os objetivos e as motivações principais deste trabalho ${ }^{6}$.

Meu primeiro contato com a literatura judaica passou por Martin Buber e suas Histórias do rabi (1965), objeto de minha dissertação de mestrado. A questão da alteridade ficou atrelada, desde então, à condição judaica, dada a forma com que foi pensada. Mas logo seria novamente problematizada, dessa vez sem resultados tão apaziguadores como em Buber. Pesquisando sobre possíveis repercussões do pensamento de Buber no Brasil, fora das áreas pedagógicas e psicológicas (que são grande maioria), encontrei a menção a Buber na tese de Saul Kirschbaum (2004b) sobre um certo escritor chamado Samuel Rawet. O primeiro contato com a ficção de Rawet foi o conto "Diálogo", do livro de mesmo título. Nesse conto, tudo acontece ou converge para o âmbito subjetivo: conflitos, tensões contidas sofridamente, hostilidade e desencontro marcam a relação desarmônica entre um pai, que desajeitadamente manifesta sua preocupação com o futuro do filho, e o filho que se divide entre reconhecer e criticar as convicções e cuidados do pai ao mesmo tempo em que insiste em seguir seu próprio caminho. O leitor está diante, portanto, de uma tensão que não se resolve e que estrutura o conto na forma de discurso indireto livre e monólogo interior. $\mathrm{O}$ conto desenha um espaço intermediário entre pai e filho: não se dá o diálogo buberiano, encontro de individualidades autoconscientes e desarmadas, mas o exato contrário disso. Com essa constatação, pensei num projeto em que se verificassem em Rawet os traços negativos da filosofia de Buber.

Aconteceu que o confronto inicial com a obra de Rawet mostrou-se muito mais fecunda e complexa que me pareceu à primeira vista. Sua estrutura intrincada e frágil, porém elaboradíssima e resistente a enquadramentos filosóficos ou identitários, mostrou-se suficiente para um tese. Nem mesmo o judaísmo é um traço óbvio em Rawet. Buber ficou de lado, mas antes, influenciou-me na delimitação do tema: a instabilidade dos sentidos nos

\footnotetext{
${ }^{6}$ Remeto também a Vilém Flusser (2011e) em Bodenlos, sua autobiografia filosófica.
} 
lugares-comuns ${ }^{7}$ rawetianos. Foi selecionado, então, um corpus de seis contos, de forma a concentrar as análises nos aspectos semânticos e estruturais dos contos. Esse corpus foi apurado e reduzido aos quatro contos que têm como personagens andarilhos e a cidade, partindo da hipótese de que esses personagens seriam o eixo em torno do qual os lugarescomuns se desestabilizam e se desconstroem, levando abaixo a estrutura em que estiveram consolidadas, mas preservando, inevitavelmente, o material de que são feitos.

Ciente das dificuldades de enquadrar os contos de Rawet em campos semânticos nomeáveis (apesar de imprecisos) como filosofia e judaísmo, perguntei-me se a relação hostil com a comunidade judaica do Rio de Janeiro, e posteriormente com o judaísmo praticado em qualquer lugar, estava presente na obra ficcional do escritor como está presente em seus ensaios. Talvez a leitura dos ensaios tenha me levado a verificar a possibilidade de explorar esse caminho, mas o fato é que a alteridade mostrou ser uma questão muito presente e ligada à ética em Rawet, seja explicitamente como em "Diálogo", seja de forma subjacente a toda sua obra, conforme apontado por Kirschbaum (cf. Bibliografia). Os traços de desenraizamento (estrangeiridade, no sentido identitário), da instabilidade de sentidos do lugar-comum, ambiguidades e indefinições desses contos protagonizados por andarilhos angustiados que procuram por algo que vai se formando e se modificando à medida que avançam, num processo que não tem fim e que paradoxalmente transparece no hermetismo do texto, delinearam personagens ao mesmo tempo comuns e peculiares que viram o mundo que vivenciam pelo avesso.

Com isso, pretendo verificar nesta tese o modo pelo qual o andarilho rawetiano pode ser interpretado como um personagem condenado pela própria lucidez e devido ao próprio desenraizamento, perceptíveis ao longo de suas errâncias. Os andarilhos têm suas “epifanias", mas elas são extremamente fugidias e instáveis, condenando-os a partir do zero depois de cada momento de lucidez conquistada. Esse grau zero da lucidez é a superfície por onde se deslocam esses andarilhos durante essas pequenas revelações nada religiosas epifanias horizontais, que perpassam o espaço, mas não se desligam da condição humana daqueles que o vivenciam; momentos fugidios que transcendem algo (alguma limitação, talvez), mas permanecem na superfície, que é onde as coisas acontecem. O material de que são feitos os lugares-comuns são distinguidos e o que estava escondido, vem à luz: valores, preconceitos etc.

\footnotetext{
${ }^{7}$ O termo lugar-comum aparece textualmente em vários contos de Rawet. Seus sentidos, bem como sua imprecisão constitutiva, serão abordados neste trabalho.
} 
Serão analisados os seguintes contos: "Kelevim", "Crônica de um vagabundo", "Reinvenção de Lázaro" e "Sôbolos rios que vão", selecionados segundo os critérios acima expostos (capítulo II, "Metodologia"). Além das análises, também serão abordadas questões inevitáveis dados os pressupostos adotados, como autoria, interpretação e identidade, além de questões mais gerais como utopia e a figura do Judeu Errante, especialmente em "Crônica de um vagabundo". O conto "Kelevim" pode ser visto como a súmula das questões mais específicas e genéricas suscitadas pelas análises. Para isso, mostra-se produtiva a análise comparada entre o conto e o ensaio "Diário de um candango".

"Kelevim" foi escrito poucos anos depois do ensaio em que narra o encontro de Rawet com o autor de Diário de um candango (1963), José Marques da Silva, candango que tomou parte no processo de construção da face não planejada da capital, a das cidadessatélites e favelas surgidas durante a construção. A Brasília de Vila Planalto, no início um acampamento de candangos, surgiu, na verdade, como resíduo da capital e do projeto político de progresso e desenvolvimento que a originou. Surgiu, portanto, como "efeito colateral" da Brasília dos prédios institucionais? A "ocupação ficcional” de Brasília ${ }^{8}$ Brasília como cenário de ficção e autoria - é uma necessidade apontada pelo autor, e vem sinalizada (mas não realizada plenamente) por Diário de um candango, o livro, e por Marques da Silva, seu escritor, um quase-autor. Como efeito colateral dos planos oficiais para a nova capital, Vila Planalto, no livro de Marques, sinalizaria (além de um indício de autoria literária) uma distopia - traço que poderia orientar uma análise de "Kelevim", o conto, e de Kelevim, o não-lugar.

O ensaio de Rawet traz elementos que ajudam a pensar as estranhas imprecisões ${ }^{9}$ de "Kelevim", Nesse conto, a estrutura narrativa precária disfarça, expondo, a estrutura delineada com traços muito vagos e nada acolhedores da cidade, do ponto de vista do personagem que transita por ela, refém do olhar do narrador e também seu criador, que o abandona ao final do conto. Kelevim, a cidade, é feita das projeções do leitor para fora do

\footnotetext{
8 “Quando surgirá um autor de Brasília?”, pergunta-se Rawet (2008, p. 163). Doravante, as citações dos textos de Rawet serão referidas pelo ano da publicação e pela localização em Contos e novelas reunidos (2004) e Ensaios reunidos (2008).

${ }^{9}$ Afinal, como um conto pode construir-se sobre tantas imprecisões, a começar pela sobreposição evidentemente, um recurso narrativo - entre narrador e autor?
} 
texto, sempre a partir das lacunas do texto ${ }^{10}$. Parece-me ser uma "carta de intenções", projeto de escrita exposto sob a forma de ficção, "necessidade real de fuga e evasão" (Rawet, 2004, p. 205). Não é simples escapismo, nem delírio abortado, mas busca: o que faltaria a Kelevim como cidade, e ao personagem que transita por ela? O que existe entre o personagem e sua cidade? Lê-se, nesse conto, um mapa feito de imagens e palavras. A consciência do personagem também é parte desse mapa de Kelevim.

Já Brasília é marco da marcha para o interior: "A marcha para o interior era o fator capaz de reordenar o sentido da ocupação. A verdadeira história seria escrita por Brasília" (Oliveira, M. apud Klidzio, N., 2010, p. 154). A história da ocupação do território nacional, da qual Brasília faz parte, tem seu equivalente na ocupação das cidades e na oposição nem sempre geográfica (mas social e econômica) entre centro e periferia, temas presentes em "Crônicas de um vagabundo", "Sôbolos rios que vão" e "Kelevim", e indiretamente (enquanto dualidades como abstrato/concreto, vida/morte, margem/centro, humanidade/animalidade etc.) em "Reinvenção de Lázaro". As dualidades Brasília/Kelevim e realidade/ficção, projeções permitidas pelo conto "Kelevim" e traçadas como prolongamentos de suas linhas de força, trazem consigo a dualidade distopia/utopia, conforme será exposto.

Como se vê, conto e ensaio convidam a extrapolar, sem desrespeitar, os limites do texto literário, até porque a estrutura entrelaçada do ensaio com o livro de memórias permite isso. Migrante e imigrante são colocados lado a lado, resguardando suas especificidades; o fato é que há um lugar em que ambos estão em pé de igualdade nesse deslocamento espontâneo do escritor-engenheiro ao escritor-candango, motivado por questões literárias. Como esse movimento repercute no texto e encontra ecos na figura do andarilho rawetiano, é o que será visto adiante. Diante de textos densos e herméticos cujo ápice, no corpus delimitado neste trabalho, é "Kelevim", levei em consideração não só os caminhos que se mostraram viáveis, mas também as incertezas que tive como leitor ${ }^{11}$. Ou seja, incorporei ao texto, em forma de perguntas e exercícios de imaginação a que o conto tentadoramente chamava, extrapolações de sentido: com isso, permiti-me seguir algumas "linhas de força"

\footnotetext{
${ }^{10}$ Esses lugares imprecisos são aberturas, preenchidas pelo leitor, que permitem a intertextualidade do conto em questão com "Diário de um candango" (o ensaio e, através deste, o livro). Só é possível ver Brasília de "Diário..." em "Kelevim" - e essa não é a única leitura possível - se o leitor responder ao arriscado apelo do texto para ser seu coautor.

${ }^{11} \mathrm{O}$ método de incorporar ao texto as desorientações que se tem como leitor de Rawet que tenta ir a fundo nesse texto de superfícies já foi usado por Lilenbaum (2009) em sua tese.
} 
(Waldman, 2004) que apontam para fora do texto, perpassando-o, quando isso se mostrasse produtivo. Um desses caminhos foi testar a hipótese de que em "Kelevim", os temas utopismo e errância se encontram, com consequências para ambos no âmbito do conto: o personagem esboçado é abandonado e o utopismo é trazido para o plano literário, desideologizando-se $\mathrm{e}^{12}$ e tomando a forma de um desiderato de cidade imaginada. Um caminho de erros, na leitura de Rawet, parece-me ser outra forma de errância, acompanhando a polissemia que a palavra "errar" tem na leitura de seus contos. Demonstrar todo o processo tanto pelo avesso como pelo direito seria análogo a incorporar os andaimes na estrutura do texto, como faz Rawet em "Kelevim”. A errância como leitor faz do próprio um co-autor do texto que percorre, atingindo-o em seus juízos, preconceitos e cegueiras. Da mesma forma com que, na literatura contemporânea em geral, os escritores "interferem na narrativa de modo a ressaltar a presença daquele que fala" (Dalcastagnè, 2012, p. 94), na literatura brasileira contemporânea o leitor é envolvido nesse "afã autodenunciador"13:

Hoje - o cada vez mais -, [...] [os escritores pretendem], em seu afã auto-denunciador, que o leitor tropece em juízos alheios, esbarre nos próprios preconceitos, que ele estreite os olhos para enxergar melhor, percebendo que também inventa aquilo que não consegue distinguir (idem, p. 94, grifos meus).

A liberdade e a perdição permitidas ao escritor estendem-se aos leitores. Ao deixar clara, e não camuflada, a presença de um narrador como mediador (mesmo obscuramente) entre o texto e seu leitor, traz-se o leitor para dentro do texto - do qual o narrador já é parte. Em perspectiva misè-en-abime, realidade e ficção, bem como autoria e leitura, refletem-se e têm seus limites borrados, ainda que se mantenham.

O início deste trabalho foi, como leitor crítico, tatear nos contos os fios que poderiam me levar à interpretação dos lugares-comuns pelos andarilhos, e pelo leitor ao lado deles. Essa estratégia mostrou-se arriscada e trabalhosa, mas adequada a contos em que o narrador sabe tanto do personagem quanto o leitor, segundo Berta Waldman (2003). Como se pode deduzir a partir disso, o começo do enfrentamento com os contos foi tateante.

\footnotetext{
12 Contudo, o traço de ideologia permanece à sombra desse conceito, mantendo-se de forma ambígua e como questão aberta.

${ }^{13}$ A autora trabalha com a literatura produzida dos anos 1960 ao ano de 2004.
} 
Definido o viés (errância e andarilhos) e o recorte (desconstrução dos lugares-comuns em Samuel Rawet), seguiu-se a dissecação (quando isso fosse possível) dos textos em unidades mínimas, a que chamei de núcleos textuais (e subnúcleos, em "Crônica de um vagabundo"). Dessa forma, definiu-se a oposição complementar centro/periferia como categoria a ser utilizada. A estrutura desta tese foi-se definindo aos poucos, em muitas tentativas e erros; as marcas desse percurso são inevitáveis. 


\section{Fortuna crítica}

Neste capítulo, passarei em revista a fortuna crítica de Samuel Rawet, detendo-me nos textos que tiverem relação direta com este trabalho. Serão verificadas, principalmente, as formas como a crítica trata de temas como errância e identidade na obra ficcional de Rawet. Outras obras serão apenas mencionadas.

O conto teria tido seu boom na década de 1960, quando Rawet publicou a maior parte de sua obra de contos. Doramundo, de Geraldo Ferraz, era apontado como outra revelação literária, ao lado de Rawet, no romance. Hoje, Guimarães Rosa é um clássico da literatura brasileira, Ferraz só é lembrado na fortuna crítica dedicada a Rawet, e o próprio Rawet tem despertado interesse universitário.

Uma pesquisa rápida revela que esse interesse acadêmico pela obra de Rawet, enfocada nos contos e novelas, cresceu nos anos 1990 e 2000, com artigos, apresentações, teses e dissertações de pesquisadores de universidades de Minas Gerais, São Paulo, Rio de Janeiro (onde existem núcleos de estudos judaicos na UFMG, na UFRJ e na USP) e Brasília, onde Rawet viveu e morreu, tendo criado um círculo de amigos literatos. Atualmente há professores universitários que estudam ou usam em aula os contos e novelas de Rawet.

Os trabalhos encontrados por mim abordam a condição de imigrante, de judeu e de outsider, procurando por reflexos desses traços identitários do autor em sua obra de ficção, como Igel (1997), que classifica Rawet como marginal, nos termos acima ${ }^{14}$. Sem negar que haja traços judaicos na literatura de Rawet, Kirschbaum (2011) dá um passo adiante e vê o escritor como organicamente integrado à literatura brasileira, mas descarta a ideia de nacional e abre espaço para "culturas literárias periféricas" (p. 93): "Se o conto de Rawet representa uma ruptura com o conto brasileiro produzido até então, creio ser essa uma ruptura orgânica, que se insere [...] numa conjuntura mais ampla de renovação da literatura brasileira, com efeitos também sobre o romance e a poesia"15 (p. 94). Chiarelli (in Santos, 2008, p. 558) também vê em Rawet a problematização de consensos ligados à identidade literária brasileira: “A ideia de um projeto homogêneo de nação é problematizada inúmeras vezes em seus escritos, que se revelam capazes de apontar a persistência de desigualdades

\footnotetext{
${ }^{14}$ A autora parece levou em consideração apenas Contos do imigrante, primeiro livro de Rawet.

${ }^{15} \mathrm{O}$ autor trata da renovação do conto brasileiro nos anos 1950, quando Contos do imigrante (1956) foi publicado.
} 
maquiadas sob o discurso da tolerância e da cordialidade" ${ }^{16}$, como o mito da miscigenação racial. Os ensaios de Rawet também foram usados por alguns desses trabalhos como apoios para a interpretação dos contos e novelas ${ }^{17}$. Algumas vezes, foram necessárias formas novas de abordar o texto rawetiano, formulando-se conceitos ou mesmo mimetizando a errância dos personagens, ao longo do trabalho de interpretação. Existe uma tese sobre clichês e convenções e o projeto literário de Rawet (Antunes, 2011), mas não sobre o lugar-comum como um conceito que os englobe.

Rawet viveu durante a juventude no subúrbio do Rio de Janeiro. A cidade existente para além do confortável centro urbano esteve presente em toda sua obra, muitas vezes como personagem. Bares, ruas e praças da cidade do Rio frequentemente são citados. Mas há contos em que a cidade é personagem, mas não tem nome nem marca distintiva: pode-se supor, apenas, que a cidade portuária em que desembarca de ônibus o andarilho de "Crônica de um vagabundo" (1967) tenha como referência direta lugares do Rio de Janeiro. É, antes de tudo, uma cidade estranha percorrida por um estranho - aspectos essenciais nos contos de andarilhos rawetianos, objetos deste trabalho. A estranheza do andarilho, sempre muito escassamente definido física e subjetivamente nos contos escolhidos para análises, acentuase e chega a ser um traço marcante também do narrador em "Kelevim", metaescrita que revela projeções éticas para fora do texto, mas circunscrito por este, como desdobramento

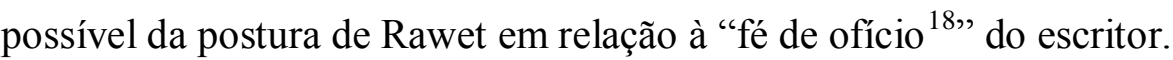

A memória da infância na Polônia é trazida no conto "Gringuinho", de Contos de imigrante (1956); a origem judaica é trazida nos ensaios e entrevistas, e traçada em alguns contos, como "Lisboa à noite" (Que os mortos enterrem seus mortos, 1981), ou mencionados de passagem, como em "Kelevim" ("cafetinagem histórica que se faz com Auschwitz"). De certa forma, a pertinência a temas judaicos evidentes é discutida nesta tese, na figura hipotética do Judeu Errante, que surge na epígrafe a "Crônica de um vagabundo".

A obra de Samuel Rawet despertou reações opostas quando da publicação de seu primeiro livro, Contos do imigrante, em 1956, ano em que Grande sertão: veredas e Corpo de baile, de João Guimarães Rosa, também tiveram suas primeiras edições. Por um lado, Renato Jobim considerou-o ilegível; por outro lado, Jacó Guinsburg considerou-o inovador

\footnotetext{
${ }^{16}$ A autora trabalha com Contos do imigrante na perspectiva dos Estudos Culturais, em Vidas em trânsito (2005), abordando a representação do imigrante como representação da alteridade, e não em termos de nacionalidade.

${ }^{17}$ Cf. Antunes, 2011.

${ }^{18}$ Título de um conto de Rawet.
} 
(cf. Santos, 2008). Parte da crítica seguinte resignou-se a explicar seus contos atribuindo à estranheza própria da escrita de Rawet sua condição de imigrante, supondo que o autor teria um olhar totalmente estrangeiro sobre a língua portuguesa. Era o início da discussão sobre a inserção de Rawet no cânone literário nacional.

Marcado pela estrangeiridade, o Judeu Errante como um tipo rawetiano foi verificado em "Ahasverus...", mas também em "Crônica de um vagabundo":

Figura dominante na obra de Rawet, o judeu errante traveste-se no homem solitário e angustiado que passa, no Vagabundo que caminha sem destino, percorrendo contos ("O Profeta", em Contos do Imigrante; "Crônica de um vagabundo", em Os sete sonhos, por exemplo), novelas (Abama, por exemplo), até alcançar a forma-síntese em sua última novela, Viagens de Ahasverus... [...] (Waldman, 2002, p. 89).

Mais recentemente, Santana Jr. (2011) fala em recriação do mito de Ahasverus em "Crônica de um vagabundo":

Outra contribuição de Rawet, conquanto não seja o foco deste trabalho, mas merecedora de alguma reflexão, para sua recriação literária do mito de Ahasverus decorre, também, da experiência desse escritor como judeu emigrado da Polônia para os subúrbios cariocas. Recriação germinada, por exemplo, na narrativa "Crônica de um vagabundo", do livro Os sete sonhos, de 1964 [1967], na novela “Abama”, de 1967, e em seus ensaios filosófico-autobiográficos, como em "Devaneios de um solitário aprendiz da ironia”, publicado no mesmo ano da novela sobre Ahasverus: 1970.

Críticos apontaram esse juízo excludente de um suposto olhar estrangeiro sobre a língua portuguesa como uma forma acomodada de se lidar com a ficção daquele autor. Críticos de hoje consideram-no pioneiro na renovação do conto brasileiro desde Machado de Assis, e de fato Rawet traz questões sobre a figura do autor semelhantes às apontadas por Abel Baptista em A formação do nome (2003) ${ }^{19}$.

\footnotetext{
${ }^{19} \mathrm{Se}$, quanto à forma, Rawet renova o conto brasileiro desde Machado, quanto ao projeto literário ele seria seu herdeiro involuntário.
} 
No capítulo sobre o ensaio "Instinto de nacionalidade" (1873), de Machado de Assis, Baptista (2003) relaciona lugar-comum e metáfora. A problematização do uso da metáfora cristalizada (lugar-comum), por Rawet, coloca o autor na corrente das tentativas históricas de definir a brasilidade da literatura brasileira. O seguinte uso de "lugar-comum", abarcado pelo lugar-comum rawetiano, traz a problematização da representação de brasilidade para o âmbito da linguagem comum ${ }^{20}$ :

Em primeiro lugar, a fundação do projeto nacional impôs uma retórica estreitamente solidária do romantismo [...]. Na verdade, tratava-se de um conjunto de proposições que espalharam e impuseram através de uma rede de lugares-comuns: 'natureza brasileira', 'aura americana, 'civilizações aborígenes', 'elemento indiano', 'gênio brasileiro', 'cor local', tudo isso corria como metáfora do Brasil enquanto fundamento último do projeto de nacionalização literária, isto é, metáfora do Brasil, ele mesmo funcionando como metáfora (Baptista, 2003, p. 49).

Em Rawet, a identidade - brasilidade, talvez - de seus personagens liga-se a termos menos pretensiosos e mais chãos, mas também muito abrangentes: sólidas convenções sociais, hábitos vazios de sentido, o senso comum paralisante. O modo como o lugar-comum é trabalhado enquanto metáfora cristalizada (morta) ${ }^{21}$, é que particulariza Rawet, que desconstrói a normalidade do lugar-comum nos seguintes termos: "O lugar-comum estipula uma coincidência entre o sentido da metáfora e o sentido do uso da metáfora, remetendo-a para a unidade de uma intenção original estável" (idem, loc. cit.). Inserido no debate sobre o projeto literário brasileiro, Rawet é representativo do "esgotamento do conceito de nacional" (Kirshcbaum in Santos, p. 571) atrelado à identidade na pós-modernidade.

Reis (2009), em sua tese, propõe o nomadismo como leitura dos personagens errantes (não necessariamente andarilhos), alternativa às leituras que privilegiam o imigrante ou o judaísmo. O vagabundo de "Crônica..." é visto, pelo autor, como um ser em constante metamorfose que se entrega ao devir. Para isso, "tem que não reconhecer seu passado e seus valores para ressurgir", metamorfoseando-se (p. 68).

\footnotetext{
${ }^{20}$ Em oposição a "elevada".

${ }^{21} \mathrm{O}$ termo "metáfora morta" é emprestado a Ricoeur (s.d), mas aproximo-o a Rawet quando falo em sentidos ou metáforas cristalizados.
} 
Discorrendo sobre "escrita diaspórica", Bines passa por "Viagens de Ahasverus..." e aponta para a vida de Rawet, ligando organicamente uma ponta a outra: "Celebrar incondicionalmente a ambiguidade, a descontinuidade, a fragmentação na escrita de Rawet seria obscurecer o quão intensamente o sentido de fratura se estende à vida do escritor. [...] Nos últimos anos de sua vida, Rawet [t]ornou-se progressivamente paranoico, com sentimentos de perseguição, e auto-ódio, desenvolvendo uma personalidade esquizofrênica" (in Santos, p. 546, grifo meu).

Uma leitura mais cuidadosa da novela "Viagens de Ahasverus...", por Waldman (in Santos, 2008, pp. 515-527), refere-se à origem judaica do autor, mas passa por referências concretas. Assim, cita um trecho de uma entrevista concedida por Rawet a Ronaldo Conde para dizer que a figura de Ahasverus "ocupa lugar de destaque nas preocupações do autor" (p. 516) e situa o judeu errante Ahasverus na história literária: “Com a passagem na literatura do século XX, Ahasverus aporta no Brasil, na novela de Rawet, em construção peculiar" (p. 517). Nesse ensaio, a autora chega a uma conclusão sobre "As viagens de Ahasverus..." que passa longe da linha traçada por Bines, citada acima: "Como a imagem de Ahasverus não se fecha, nem se congela no texto, ela implode a figuração do judeu enquanto estereótipo, retirando-o da posição de continente de significados antissemitas historicamente dados, para lançá-lo na arena do jogo linguístico, onde os sentidos não se fixam” (p. 527).

Ambas as autoras respondem, de formas antagônicas, à observação de Chiarelli, em artigo sobre a recepção da obra rawetiana (in Santos, p. 595);

O problema da recepção da obra de Rawet se complexifica quando a abordagem se dá por certos críticos de descendência judaica, bastante rigorosos quanto ao julgamento das atitudes do autor. A literatura de Rawet gera sempre uma espécie de incômodo que torna problemática a abordagem desses textos por não participar de uma dita 'literatura judaica', vale dizer, que represente valores específicos que visem à perpetuação de estereótipos, ou mesmo à institucionalização da origem, que reforça a identidade.

Neste trecho, Chiarelli problematiza o rótulo "literatura judaica" ao relacioná-la a posturas "cristalizadoras", rígidas, que embasassem a crítica rawetiana à identidade judaica do autor $^{22}$, e a questões sobre identidade judaica, tendo como pano de fundo sua obra

\footnotetext{
${ }^{22}$ Em Vidas em trânsito... (2007), Chiarelli aponta o auto-ódio atribuído a Rawet por Igel (1997)
} 
ficcional (Bines) $)^{23}$. Temas como imigração, exílio e memória estão inquestionavelmente relacionados à tradição judaica em Contos do imigrante, mas já a partir de Diálogo (1963) essa ligação se torna progressivamente mais complexa e sutil ${ }^{24}$. Em outro artigo, Chiarelli se vale da figura do Judeu Errante, embasando-se em Contos do imigrante (1956) e apontando para a problematização da "ideia de um projeto homogêneo de nação" (idem, p. 558). Contextualizando historicamente a obra de Rawet, e o autor no contexto de imigração, Kirschbaum (idem, p. 562) traça um panorama da mesma:

A obra de Rawet é marcada por duas características principais: uma profunda preocupação ética que transparece na criação das personagens sobreviventes do holocausto, migrantes incapazes de se adaptar, doentes terminais - e repercute até mesmo em seu fazer literário, desdobrado metalinguisticamente (cf. "Parábola do filho e da uva" e Viagens de Ahasverus), e um relacionamento particularmente difícil com o judaísmo. Mais do que com o judaísmo, com os judeus. Na verdade, penso que os dois polos são aspectos de um mesmo fenômeno, afetando-se e reforçando-se mutuamente.

Para o autor, o judaísmo de Rawet tem reflexos conscientes e problematizantes em sua obra. A rigor, sua origem não determinaria por si só a judeidade de sua literatura e sua pertença ao delicado e complexo campo da chamada "literatura judaica", da qual Chiarelli expõe os perigos. Formas de se interpretar - no texto literário - as memórias históricas e pessoais que atravessam a vida e obra de Rawet.

Vieira (1995), por sua vez, também se vale de dados biográficos para interpretar o pensamento e a obra de Rawet. O crítico atribui a "postura antijudaica" ("anti-Jewish stance") do Rawet de "Kafka e a mineralidade judaica..." a "distúrbio psíquico" motivado por "circunstâncias específicas" mas reconhece o valor literário do artigo: "The article hints at Rawet's complex view of his ethnicity as well as the complicated social makeup of the Brazilian-jewish community" (p. 58),

\footnotetext{
${ }^{23}$ Não estou dizendo que a supervalorização do desequilíbrio psíquico de Rawet é exclusiva de críticos judeus, mas que esse desequilíbrio está ligado a um suposto "auto-ódio judaico" (Igel).

${ }^{24} \mathrm{O}$ leitor crítico deve, então, acompanhar esse movimento e não cair na armadilha da judeidade como panaceia interpretativa.
} 
O ensaio "Modos de conexão" mostra como posições críticas podem ser torcidas a ponto de camuflarem tipos originais, como os andarilhos, em metáforas mortas. Insistindo na pertença judaica do autor, Bines (in Kirschbaum, 2007, pp. 55-71) afirma que destacar tanto as qualidades de sua obra quanto sua condição imigrante são formas cômodas com que a crítica lida com sua originalidade. Seriam, segundo a autora, "lugares de suspensão" que o salvariam do contato com o "solo concreto em que se movem e se debatem as obras, no corpo a corpo da vida literária" (idem, p. 60). A partir de um insight de Assis Brasil sobre "Viagens de Ahasverus..."25, Bines intui que "em Rawet é o mundo judaico que traz a diferença e o desconforto para o corpo da linguagem" (idem, p. 61), elencando a seguir as formas em que se manifestaria essa herança judaica - sem, contudo, limitar-se à novela em questão:

São personagens com nomes em ídiche; referências a passagens bíblicas, a errância como tema e experimento estético na condução de enredos inquietos, sem pouso certo, movidos por uma escrita itinerante e aflita, que se torce e contorce na modulação do drama da existência (idem, loc. cit.).

A observação, que parte de temas e chega às formas de tratamento do enredo, caberia também em Contos do imigrante (1956), anterior a "Viagens..." (1970). Nesta novela, o componente judaico é óbvio na figura de Ahasverus, e ocorre de um modo que não se encontra em Clarice Lispector, a quem Bines entende a influência "do ambiente judaico de sua formação" a partir de uma entrevista de Rawet a Ronaldo Conde (in Kirschbaunm 2007, p. 61). Nela, Rawet diz que não é "muito apropriado" estudar a linguagem em Clarice "como se ela fosse intencional", pois "o que ocorre com Clarice é um tipo de consciência particular que ela tem. Um modo específico e completamente diferente de ver a realidade. Com a ambiência que ela teve até a fase de adulto, tudo isso forma uma consciência particular" (idem, loc. cit.). Com isso, conclui que, quando "Rawet reflete sobre a sua própria produção [valendo-se de Clarice], desaparece a conexão positiva entre condição judaica e arrojamento estético para dar lugar à consciência dilacerada de que aquilo que

\footnotetext{
${ }^{25} \mathrm{O}$ insight é o seguinte: Assis Brasil ensaiaria um "brevíssimo movimento na direção comparativa, quando equipara as obras de Rawet e de [Guimarães] Rosa: 'no plano em que a informação cultural é o próprio instrumento criador e de afirmação moral"” (idem, p. 60).
} 
torna sua escrita 'única' é também o que a desqualifica como genuinamente 'brasileira", (in Kirschbaum, 2007, p. 62, grifos meus).

Até aqui, compreende-se a necessidade e funcionalidade de se destacar a presença de uma possível consciência judaica em Clarice, mas Bines volta a referir-se à figura do imigrante $^{26}$, o que faz parecer que os traços judaicos em Rawet (assim como em Clarice) se circunscrevem a sua condição de imigrante. Dessa forma, a "consciência judaica", possível em Clarice (e em Rawet, a partir de seu olhar sobre Clarice), seria a "consciência dilacerada" que toma a forma mais generalizada de "consciência aguda" em Rawet:

O que a literatura de Rawet nos comunica a ferro e fogo é a consciência aguda desta dor de estar-no-mundo, da qual não há liberação. [...]. O judeu imigrante de Rawet não encontra nem casa nem família no Brasil, tais instituições figuram em sua obra apenas como ruínas, espaços em desagregação (idem, p. 63, grifos meus).

Ora, nem "Ahasverus,.." nem toda a obra de Rawet por completo (mas parte dela) tratam do judeu imigrante exclusivamente ${ }^{27}$. A autora volta ao ponto inicial de sua argumentação e iguala "consciência dilacerada" a "imigrante judeu", religando "condição judaica" e "arrojamento estético", neutralizando assim o impacto de qualquer "consciência dilacerada" que se veja em algum personagem rawetiano que não seja imigrante judeu.

Logo em seguida, Bines passa a verificar o contexto de recepção ao judeu que imigrava para o Brasil, chegando a falar em "auto-ódio" judaico. (idem, p. 64) e afirmando que as metamorfoses de "Ahasverus..." "representam menos uma experiência libertária de invenção de identidades, do que uma estratégia de sobrevivência, uma forma de não se deixar aprisionar por qualquer espécie de rótulo" (idem, p. 66). Nessa perspectiva generalizante, é claro que o vagabundo errante seria apenas a exteriorização auto-defensiva de estereótipos do judeu. ${ }^{28}$ Nesse sentido é que o judeu imigrante "generaliza-se em livros posteriores na figura do homem marginalizado, anônimo, o "ser de fronteira"” (idem, p. 67): o judeu imigrante sobrepõe-se à representação do "homem marginalizado", acabando por naturalizar um traço que, segundo argumentação da autora, seria judaico a priori - a

\footnotetext{
${ }^{26}$ Dessa vez, na obra, e não na biografia de Rawet.

${ }^{27}$ Pelo menos, não na exclusividade étnica sugerida tortuosamente pela autora.

${ }^{28}$ Posição da qual discordo, como será visto adiante.
} 
estrangeiridade como metáfora naturalizada de qualquer forma de desajuste e marginalidade. A consciência dilacerada em Rawet cristaliza-se, perdendo sua força de metáfora viva, e não mais provoca a interpelação mútua entre os dois termos da identidade hifenizada "judeubrasileiro", como quer Bines ao ressaltar o primeiro termo desse binômio.

Levy (in Kirschbaum, 2007, pp. 72-87) também afirma a errância na literatura rawetiana, tomando como exemplos concretos Ahasverus e os vagabundos "que erram pela cidade do Rio de Janeiro" (p. 74). A autora também relaciona os vagabundos, via Ahasverus, com traços judaicos na escrita de Rawet:

Por mais que ele tenha tentado se colocar apenas como um escritor brasileiro, negando, sobretudo no fim de sua vida, sua relação com a cultura judaica, seus textos revelam abertamente as marcas dessa cultura. Não somente pela presença constante de personagens judeus, mas também pela insistência em tratar de questões nitidamente judaicas, como a diáspora, a imigração e a condenação à errância eterna, como no caso de Ahasverus, personagem central de uma de suas novelas. Nesse sentido, sua literatura é intrinsecamente judaica, ainda que de um judaísmo sem Deus (pp. 73-74).

Creio que o vagabundo rawetiano extrapole o âmbito das "questões judaicas", embora esteja ligado às mesmas. A condição de imigrante e judeu de Rawet, mais que um aparente estigma identitário inescapável ${ }^{29}$, é fonte de memória criadora, como afirma a mesma autora, algumas páginas adiante: "Em primeiro lugar, talvez seja importante entender o corpo como memória" (idem, p. 81). Nesta tese, tento refazer o caminho identitário sugerido pela figura do andarilho rawetiano, baseando-me na dinâmica peculiar criada pelo texto rawetiano.

Já para Valeska, no mesmo volume (pp. 101-117), Ahasverus e o vagabundo de "Crônica..." estão ligados pela traição de valores: "O traidor, em Rawet, não engana: o fantasma está em toda parte. A traição, que se desdobra, é, na verdade, uma escolha, um programa e, mais ainda, uma exigência”. Citando Deleuze e Guattari, diz que nesse "contexto, o gesto de trair não se refere a um posicionamento crítico, mas à tarefa de tocar o

\footnotetext{
29 "Por mais que ele tenha tentado se colocar apenas como escritor brasileiro, negando sobretudo no fim de sua vida, sua relação com a cultura judaica, seus textos revelam abertamente as marcas dessa cultura" (p. 73)
} 
próprio acontecimento, escolher o combate que não quer deixar qualquer marca na história, mas afetar e ser afetado no tempo prolífico do agora" (in Kirschbaum, p. 109). A errância de Ahasverus, fantasma traidor que permeia os andarilhos de Rawet, é a mesma do vagabundo - que, no entanto, não carrega o estigma de "judeu maldito, condenado à errância eterna" (p. 110).

No mesmo volume, Tonus (pp. 119-135) desenvolve uma leitura comparada de "Ahasverus..." e "Abraxas" com outras obras, conforme proposto por Bines, em texto do mesmo livro; também trata do hibridismo em ambas as novelas, conforme a visão pósmoderna sobre a chamada literatura judaica brasileira proposta por Kirschbaum (in Santos, 2008, pp. 561-574).

Em sua tese, transformada em livro, $\operatorname{Kirschbaum}(2004$, p. 2), afirma que "a postura ética manifestada por Rawet em sua literatura não pode ser dissociada de sua 'questão judaica"”, que o autor localiza no rastro da Emancipação judaica após o sanedrin convocado por Napoleão em 1806, na França. Nas palavras do autor, a difícil relação de Rawet com o judaísmo - "com os demais judeus" - deve ser buscada historicamente:

Penso que a resposta deve ser buscada no processo histórico da modernidade européia, que resultou no surgimento e consolidação do estado-nação. Ou seja, na Idade Média, teocêntrica, a identidade construía-se em torno da religião. Esse arranjo permitia que também os judeus tivessem uma identidade sólida, centrada, estável, por mais que gerasse exclusões, expulsões, acusações de "crimes rituais". No entanto, a partir do Iluminismo, da Revolução Industrial, e mais fortemente da Revolução Francesa, o teocentrismo é substituído pelo antropocentrismo, e a identidade básica desloca-se da religião para a nação. Agora o indivíduo não é mais principalmente católico ou protestante, mas francês ou inglês (idem, p. 143).

A pós-modernidade precoce surgida entre os judeus após a Emancipação, diz o autor, explica características dos personagens de Rawet:

nos textos de Rawet, não apenas os protagonistas são fragmentados enquanto sujeitos, não conseguem situar os limites de suas identidades nem 
alcançam perceber o real de forma orgânica, racional, mas apenas de forma fragmentária; e mais, os próprios textos abdicam de uma possível totalidade para mostrar tempos e espaços recortados, descontínuos, não-lineares (Kirschbaum, 2004, p. 139).

A "questão judaica" de Rawet se manifesta em sua preocupação ética e de consciência crítica suscitada pelo sentimento de responsabilidade perante o Outro. Daí afirmar que "ética na literatura e relacionamento difícil com o judaísmo concreto são aspectos de um mesmo fenômeno" (idem, p. 146). Rawet é visto como escritor intimamente ligado às questões éticas e históricas de seu tempo, sob as quais se assenta sua "questão judaica”. O amplo panorama de sua obra, ensaios inclusive, traz fundamentos para a análise de sua ficção ao propor formas específicas de se abordar o texto rawetiano, suscitadas pelas necessidades encontradas com sua leitura.

Uma análise detida de um grupo coeso e específico de contos e personagens, como a que proponho neste trabalho, também parte da necessidade de se criar novas formas de se abordar o texto de Rawet - os contos, especificamente. A forma cerrada com que abordo os contos exige que me atenha ao texto, mas não impede que encontre neles ecos ou fantasmas que decorrem da "questão judaica" exposta acima por Kirschbaum. Sem, contudo, cair em essencialismos ou generalizações homogeneizantes.

O não-engajamento político de Rawet pode significar a auto-afirmação de sua liberdade criadora de ficcionista e o compromisso único com sua responsabilidade ética. Para isso, chafurda no lugar-comum e se recusa a sair de lá, a despeito do que parecem dar a entender seus ensaios filosóficos. Diz Costa (1979, p. 132): "Pensar dentro da alienação sem tentar denunciá-la (já que extirpá-la é um longo processo, só possível talvez em termos políticos) é não sair de um círculo fechado"30. Pois o campo de atuação de Rawet é a metáfora, e não a filosofia ou a política ${ }^{31}$ : "E aí, da mesma forma como em Rawetficcionista, é a ficção que interessa e não a filosofia, é a percepção metafísica transformada

\footnotetext{
${ }^{30}$ Clarice Lispector também estaria nesse "círculo fechado de alienação", ocupado por esses herdeiros de Kafka, segundo o crítico.

${ }^{31}$ Por isso mesmo, acrescento, não haveria necessidade de se cobrar rigor filosófico em seus ensaios filosóficos, verdadeiros exercícios de consciência, feito de tentativas e erros, de um ficcionista.
} 
em 'parábola do círculo'; é a metáfora: a arte, a criação" (Costa, 1979, p. 143, grifos meus) $)^{32}$.

Destrinchar ou mergulhar na estrutura dos contos pareceram ser dois modos básicos de se deixar envolver pelo universo rawetiano, nas teses e dissertações: um desmancha para analisar, outro preserva para deixar-se levar. Os pontos de partida vão desde a investigação sobre a própria judeidade das autoras ${ }^{33}$ como o interesse pela figura do outsider $^{34}$, presente nos andarilhos de Rawet: pergunta-se sobre características da literatura judaico-brasileira, a partir da obra rawetiana de ficção como um todo, ou a partir dos "tipos" muito frequentes nessa obra e muito semelhantes entre si, como o andarilho, o desenraizado e o sujeito angustiado por algum trauma passado. "Tipos" esses que se combinam nos personagens, criando figuras em conflito - com o outro ou consigo mesmo, nas mais diversas formas que isso pode ter: recusa de convenções, ódio, busca pelos sentidos da vida. Bazzo (in Kirschaum, 2007), por sua vez, tem uma aproximação muito pessoal a de Rawet como escritor e indivíduo, que faz lembrar alguns ensaios do próprio autor.

O estranhamento é o traço comum aos "tipos" rawetianos; sua construção mostra a variedade que os mesmos podem assumir diante da complexidade da vida humana: assim, o imigrante de aparência estranha, vindo de uma catástrofe e que se sente estrangeiro em meio à própria família ("O profeta", in Contos do imigrante, 1956) compartilha do estranhamento (vivido pelo personagem e pelo leitor) de "Brrkzng: pronúncia - bah!”, ao questionar-se sobre a relação entre palavra e objeto (in Que os mortos enterrem seus mortos, 1981). Como ferramenta, a filosofia, primeiro recurso a se pensar num texto tão reflexivo como o Rawet de Os sete sonhos (1967, em que está a maior parte dos andarilhos rawetianos), é utilizada em alguns dos trabalhos, especialmente autores como Deleuze e Foucault ${ }^{35}$. A natureza literária dos textos, entretanto, é preservada e mantida em primeiro plano. Ensaios publicados em revistas eletrônicas, bem como apresentações em congressos e congêneres,

\footnotetext{
32 O círculo é a imagem criada pelo autor para sugerir a alienação que circunscreve a ficção e que se deve romper pela ação, numa visão engajada politicamente e que pode englobar a literatura. Rawet abriria mão da literatura engajada.

${ }^{33}$ Cf. Lilembaum, 2009 e Engellaum, 2006. Abordagem legítima como ponto de partida, a meu ver, mas potencialmente engessadora. A obra de Rawet extrapola rótulos por sua própria dinâmica interna que, como leitor, procurei explorar.

${ }^{34}$ Cf. Ázara, 2012 e Reis, 2009.

${ }^{35}$ Cf. Reis, 2009.
} 
contribuíram para a divulgação e a pesquisa desse autor que vem sendo resgatado com intensidade desde a última década (meados de 2000).

A densidade dos temas presentes direta ou indiretamente em Rawet pauta a sutileza com que os recortes diferem entre si. A errância é um tema recorrente nos estudo sobre Rawet, e muitas vezes associada a Exílio e judaísmo: A novela "As viagens de Ahasverus..." suscita análises da lenda do Judeu Errante, mas em menor grau em "Crônica de um vagabundo". Neste trabalho, proponho uma leitura mais detida dos ecos e sombras da figura do Judeu Errante que se encontram nesse conto. Rawet mostra que se dobra sobre si mesmo quando passa sutilmente pela questão da alteridade e suas implicações, como a ética.

A participação do leitor é mais clara ainda nas errâncias dos andarilhos de contos como "Sôbolos rios que vão", "Crônica de um vagabundo" e "Kelevim", de Os sete sonhos, objetos de análise nesta tese, ao lado de "Reinvenção de Lázaro", (de O terreno de uma polegada quadrada, 1969). O movimento em todas suas acepções - física, metafórica, psicológica $^{36}$ - é a tônica desses contos: Ódio e indiferença movem o vagabundo de "Crônica..."; já o personagem de "Kelevim" move-se por uma cidade de contornos pouco definidos e conflitantes. Os andarilhos de Rawet, em especial os de "Crônica..." e "Viagens de Ahasverus...", e a vivência urbana evidentemente já foram temas de trabalhos acadêmicos.

Alguns pontos de apoio, ainda que instáveis e pouco claros, estão presentes: os lugares-comuns, entendidos nos contos como convenções - senso comum, imagens gastas, cristalizações de sentidos e outros termos que indiquem ruptura entre a subjetividade e a palavra, na forma da petrificação do signo. É isso o que entendo, no recorte feito para esta tese, por aquilo que Rawet chamava cristalização de valores. A própria vastidão e imprecisão do termo lugar-comum, presente textualmente em Rawet, traça linhas de força que extrapolam os limites do texto, apontando de dentro para fora (sempre) questões como ética, identidade e alteridade - temas abordados em conjunto no livro Viagens de um caminhante solitário: ética e estética na obra de Samuel Rawet (Kirschbaum, 2011).

Esse "solitário caminhante do Planalto" 37 , imigrante judeu, engenheiro e escritor malicioso confirmaria, pelos dados apresentados, a suposta autorreferência "evidente" em

\footnotetext{
36 “Derivação: sentido figurado. Incutir, inspirar, despertar”. Fonte: Dicionário eletrônico Houaiss da língua portuguesa 3.0.

${ }^{37}$ Título de um depoimento de Rawet dado a Esdras do Nascimento e publicado na revista Ficção em 1976 (cf. Santos, 2008).
} 
sua ficção. No entanto, a dificuldade diante dos textos densos e desconcertantes, e os convites tentadores a delírios interpretativos também fazem desconfiar da facilidade com que traços autobiográficos seriam descobertos. A complexidade aumenta nos contos metalinguísticos, como "Kelevim", e nos contos que chamarei aqui de oníricos, como "Sôbolos rios que vão" e "Crônica de um vagabundo", a serem trabalhados. Mas uma visão panorâmica, para além da metaescrita, em que são mais bem visualizados não só os mecanismos estruturadores do conto, como também as "linhas de força" (Waldman, 2004) geradas pelos mesmos, permite abordagens e inferências pertinentes, se tomados os devidos cuidados metodológicos. Como exemplo, as abordagens filosóficas ${ }^{38}$, caminho não tão evidente como pode parecer à primeira vista, em se tratando de uma obra ficcional que pede um leitor reflexivo e desestabiliza sentidos cristalizados (lugares-comuns da linguagem). Outra abordagem possível, mais arriscada, seria seguir a linha de força que parte de Kelevim e aponta, sem tocar ${ }^{39}$, a nascente Brasília ${ }^{40}$ - abordagem que também contempla a vivência do espaço urbano de que tratam tanto "Kelevim" quanto os contos oníricos.

Diante de possibilidades como essas, cabem alguns cuidados. A autonomia literária da ficção de Rawet é ressaltada na tese de Kirschbaum (2004), que afasta biografismos e destaca o caráter ético de sua literatura. "Pela forma e nada mais" (Adorno apud Kirschbaum, 2007, p. 52), Rawet resiste ao "adesismo inescrupuloso, indiferença ao regime de opressão e injustiça que campeava solto, talvez mesmo cumplicidade com a ditadura militar" (idem, p. 50), por parte da comunidade judaica. No entanto, a postura ética de Rawet pode ser vista também na necessidade que o autor vê de Brasília ter existência literária - e na possibilidade de que isso venha a acontecer com um ex-candango: "quando surgirá Brasília como cenário de ficção, quando surgirá um autor de Brasília? O que eu tinha entre as mãos [o livro de memórias Diário de um candango (1963)] não era ficção, mas o autor estava ali presente" (Rawet, 2008, p. 163).

Um percurso entre Klimontów, cidade natal de Rawet, e o Rio de Janeiro, presente em muitos de seus contos, foi feito por Natalia Klidzio, com o auxílio de conceitos de

\footnotetext{
${ }^{38}$ Cf. Reis, 2009.

39 "Kelevim" é uma realidade abortada: se Kelevim existisse... Como exercício de imaginação, a cidade não chega a ser criada, mas o conto se estabelece como criação textual, invenção imaginária que remete a realidades vividas (pelo autor, pelos autores lidos pelo autor etc., numa corrente ininterrupta de diálogos cuja origem é inimaginável e cujas expansões, imprevisíveis).

${ }^{40}$ Neste último caso, tem-se como pressuposto a dinâmica das linhas de força de "Kelevim”, que será vista adiante.
} 
Michel de Certeau, autor do qual também me valho em meu trabalho. Em Itinerário urbano na vida e obra de Samuel Rawet (2011), a autora trabalhou os temas da imigração e da inserção ativa do imigrado na cultura nacional a partir da vida e obra de Rawet, privilegiando a leitura de seus ensaios e ficção. Sua abordagem sociológica partiu do próprio texto rawetiano, aliado ao pensamento expresso em ensaios e entrevistas.

Saindo da linha socioliterária adotada pela autora, mas tributária dela, proponho uma análise de "Kelevim" como espaço literário (ficcional e textual) a ser vivenciado, valendo-me de alguns conceitos de Certeau. A vivência do espaço urbano é diretamente trazida à tona em "Kelevim", cidade imaginária e - suspeita-se - distópica: distopia como projeção negativa do estado de coisas atuais ${ }^{41}$. A cidade e o cidadão solitário em sua responsabilidade são figuras centrais numa Utopia: "Em toda utopia a Cidade é o elemento fundamental, com a sua organização e o seu devir terreno; é uma construção humana fundada sobre a fé na salvação do homem não por meio de uma graça transcendental, mas por ele mesmo" (C. Berriel). O papel de Rawet como engenheiro na construção de Brasília, localizada no centro geográfico do país (como Aircastle, a capital da ilha Utopia; cf. More, 2009) tem seu complemento no indivíduo que se lança para além dos centros confortáveis das cidades, como no ensaio-crônica "Diário de um candango" (cf. Rawet, 2004). Brasília representada por sua periferia é onde Rawet engenheiro encontra-se com Rawet escritor.

Mas as utopias clássicas (Utopia, de T. More; Cidade do sol, de Campanella; Nova Atlântida, de F. Bacon) pressupõem um projeto político. Logo, um engajamento. Cabe então a seguinte pergunta: o conto "Kelevim" denotaria engajamento por parte de Rawet? Nunca um engajamento ideológico, mas ético, ainda que desesperançoso (cf, Kirschbaum, 2011). Distopia que tem como objetivo natural sensibilizar o leitor para a(s) utopia(s) latente(s) na mesma, como clivagem em potencial do que o senso comum espera - conforme a leitura que

\footnotetext{
41 “Apresentação" (revista "Morus”). Disponível em: http://www.unicamp.br/ berriel/morus.htm . Acesso em: 05/2012. Esta definição propõe, como meio de se alcançar a salvação por meios humanos e não transcendentais, um ideal humanista social que tem em si , paradoxalmente, o germe do autoritarismo, ao se privilegiar o coletivo sobre o individual: "Há em toda utopia um elemento distópico, seja expresso ou tácito, e vice-versa. Em ambos os casos a realidade é distópica e exige um novo projeto. A utopia pode ser distópica se não forem compartilhados os pressupostos essenciais, ou utópica a distopia, se a deformação caricatural da realidade não for aceita. (in "Proposta de criação do U-TOPOS - Centro de Estudos sobre Utopia, IEL, Unicamp”. Grifo meu).
} 
se faz do ensaio "Diário..." - a partir do estabelecimento da nova capital. Kelevim

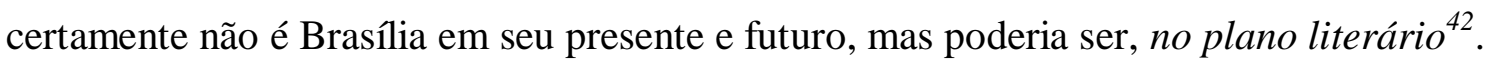

A partir dos lugares-comuns rawetianos, conforme expostos neste trabalho, essas e outras possibilidades trazidas pelo trabalho formal, em Rawet, serão abordadas.

\section{Metodologia}

Após o levantamento das ocorrências do termo, bem como dos sentidos ${ }^{43}$ que podem ter a expressão "lugar-comum" nos contos de Rawet, procurou-se delimitar seus campos semânticos, de modo que fosse possível a interpretação desse termo tão abrangente e impreciso, estruturador importante dos contos de Rawet a serem analisados neste trabalho. Buscou-se, para isso, traçar um panorama do que se entende aqui como lugar-comum em Rawet, de forma a visualizar as linhas de força que o compõem. Não foram encontrados lugares-comuns, nem mesmo no modo como foram entendidos no conjunto da obra de contos do autor, no livro Contos do imigrante (1956).

Diante do levantamento inicial dos lugares-comuns, pode-se entendê-los com as seguintes conotações: banalidade, hábito, prosaísmo, convenções (sociais, ficcionais), conveniências, senso comum, certezas (morais, éticas), clichês, estereótipos (do judeu, do negro, da feminilidade etc.). O levantamento dos lugares-comuns nos contos de Rawet sugere os seguintes pontos a serem desenvolvidos, dentro do campo semântico abrangido por esse termo e da forma como foi entendido: ambiguidades esgarçadas e não resolvidas; opostos que convivem (não sem conflito), e que não se anulam, complementando-se; cotidiano rotineiro; convivência humana e seus problemas insolúveis; contradições existentes (e recalcadas) no senso comum.

O lugar-comum rawetiano, mesmo que nomeado, não é, em si e em suas várias acepções, um termo preciso. Deve ser visto pela dinâmica de sentidos que cria no texto literário.

\footnotetext{
42 "Crônica de um vagabundo" já foi analisado comparativamente à Berlim do filme Alice nas cidades, de Wim Wenders (cf. Bibliografia: Azara, 2010).

43 Tome-se, por exemplo, o sentido de "convenção": o termo é um lugar-comum que se refere tanto a convenções sociais quanto a convenções sobre a forma "conto". A partir dessa constatação, foram buscadas as ocorrências de "convenção" nos contos. Da mesma forma, "senso comum” também é uma noção abrangida por "lugar-comum", tendo sentidos próximos de "convenção" e "clichê".
} 


\section{Lugares-comuns}

[...] a torre de marfim, em Guimarães Rosa, é o óbvio ululante

(Nelson Rodrigues, 1967).

O termo "lugar-comum" aparece em "Reinvenção..."44 e "Kelevim"45 como convenções do conto (e convenções sociais, na forma como será vista); em "Crônica..."46 como convenções sociais, senso comum, certezas e clichês; em "Sôbolos..."47 como senso comum (convenções sociais, valores médios). O esmiuçar do lugar-comum revelaria, nos contos escolhidos, "camadas que ainda não foram apresentadas ao leitor" (Flusser, 2011a, p. 152). O lugar-comum em Rawet seria, então um grande texto sobre o qual se funda a vida dos personagens andarilhos, a ser subvertido para que suas camadas de sentido possam vir à tona - à superfície, onde se dá a própria vida em si, conforme depreende-se dos contos cujos eixos são esses andarilhos.

Quanto à forma, o lugar-comum está nas fábulas, nos valores (a caridade em “Crônica...") e nas metáforas ou provérbios ("Esse tipo deveria ter um fecho-éclair na bunda" e "lamber sabão" em "Sôbolos rios...";o lobisomem e o medo infantil do escuro, no mesmo conto, Rawet, 2004, pp. 184 e 190). São formas populares que veiculam valores e imagens acessíveis ao leitor familiarizado com a linguagem popular. Daí, também, o uso de palavrões e expressões chulas nos contos rawetianos em geral. Obedecendo à mesma dinâmica de sentidos, o efeito do lugar-comum é assimilado pelo leitor segundo os parâmetros do contexto em que aparece. Assim, o gastíssimo "lamber sabão" causa espanto não quando é tomado no sentido figurado, mas quando é entendido ao pé da letra. É

\footnotetext{
44 "À medida que a história ia tomando corpo dentro dele, e a personagem ia surgindo difusa, paralisava-o uma absoluta ignorância, consciente dela mesma, do termo que lhe serviria de salvação: convenção" (Rawet, 2004, p. 306).

45 “A nítida sensação de uma ideia a ser contida, controlada, de duas talvez simultâneas a se dilacerarem ou uma a ser reintegrada sem eu campo de convenções. Os objetos oscilam entre sólida presença e puro conceito" (idem, p.207).

46 "O que era tido como aparente, secundário, era o mais importante" (idem, p. 213). A dinâmica estabelecida por essa inversão é que apontará os lugares-comuns.

47 "Eternidade, sonho, glória, instantes de cintilação, saltos de crista em crista de ondas de medo e euforia, a imortalidade das estrelas, os abismos da alma, a última convenção de uma harmonia de palavras" (idem, p. 187).
} 
metáfora morta cuja origem se perdeu no tempo. ${ }^{48}$ Indício, a meu ver, de subversão do lugarcomum por uma forma de humor perfeitamente lógica, embora indique loucura.

As paráfrases comentadas a seguir, longas porém necessárias diante da imprecisão intrínseca ao termo, buscam delinear o lugar-comum rawetiano pela dinâmica que cria nos textos.

Em "Crônica de um vagabundo", o vagabundo da novela é o andarilho ("aquele que vaga"), e não o desocupado imprestável, no sentido pejorativo mais conhecido. Sua experiência interior funde-se com a percepção da cidade. Ao lado dos que mergulham em suas dúvidas, angústias e ódio. "Cumpria o destino que quase todos cumprem, e que só a uns poucos é evitado, esses que nunca duvidam de um único gesto ou palavra, que têm a rara felicidade de um desconhecimento absoluto" (Rawet, 2004, p. 212, grifo meu). O vagabundo busca cumprir seu destino, o que exclui a "felicidade de um desconhecimento absoluto". Essa felicidade não é destinada aos outros, grupo dos que o vagabundo faz parte; os que "ousam se conhecer realmente, adquirem o hábito do terror proporcional à intensidade da descida em si mesmo" (idem, loc. cit., grifo meu). A dinâmica instaurada pelo lugar-comum liga-se sobretudo a inversões. O termo "lugar-comum é expresso textualmente: "Naturalmente chego a momentos sublimes, se puderes reprimir a ironia, e me conceder o direito a um caminho que vai por baixo; bem por baixo; se me concederes um outro direito, também, o do lugar-comum, que essa coisa de ir por baixo, bem por baixo, já está meio batida; mas por isso mesmo" (idem, p. 224).

Em "Reinvenção de Lázaro", Yehuda Bitterman decide-se escrever sobre um certo Tião, num exercício que lhe daria prazer. A visão de dois operários chama-lhe a atenção e acaba por influenciar na escrita de seu conto. Pensa em sair; passa por diversos pontos da cidade e remoi uma "idéia que poderia ser transformada em história, talvez, de um homem que tem que conquistar dolorosamente, nos mínimos detalhes, todos os episódios que compõem um cotidiano" (idem, p. 307). Deveria partir do nada, como um homem "que tudo houvesse esquecido": decide que deveria descrevê-lo por dentro. Mas como agir? Pensa então numa "receita" de conto a qual se amparar, ou seja, num conto convencional: "Eis um objeto, transforma-o em palavras, precisas, adequadas, de preferência agradáveis, cuidado

\footnotetext{
${ }^{48}$ O efeito oposto, provocado por uma metáfora viva, seria algo como: "lá, onde você é amigo do rei", remetendo ao verso de "Vou-me embora pra Pasárgada" (M. Bandeira): "Lá sou amigo do rei" (Fonte: http://www.jornaldepoesia.jor.br/manuelbandeira02.html ). Ser "amigo do rei" normalmente desperta automaticamente curiosidade quanto ao sentido poético da expressão, e não quanto a um improvável sentido literal.
} 
em não chocar sensibilidades ou valores, controla a imaginação, esconde os andaimes, revela apenas o resultado e ficaremos todos contentes com a oferta e a aceitação do ilusório" (Rawet, 2004, p. 308). No entanto, escreve seu conto tendo em vista o oposto do que considera um conto convencional: choca valores e sensibilidades, expõe os andaimes. $\mathrm{O}$ acaso e a consciência das limitações de um mero "exercício prazeroso" levam-no a expor lugares-comuns do conto como soluções confortáveis que fazem disso um "exercício prazeroso" (diletante), e a propor uma alternativa: o conto em si.

Em "Kelevim", os lugares-comuns não são nomeados, mas apenas indicados pelo próprio impulso de se escrever um conto: "Kelevim não existe. É produto da imaginação, chamem-na assim, e da necessidade real de fuga e evasão. Uma espécie de auto-alienação" (idem, p. 205). Do que o autor-narrador se aliena ${ }^{49}$, e quem é o personagem abandonado que irrompe no conto, são questões constitutivas desse conto "abortado": "A nítida sensação de uma ideia a ser contida, controlada, de duas talvez simultâneas a se dilacerarem ou uma a ser reintegrada em seu campo de convenções" (idem, p.207). Em "Kelevim", mapear o lugarcomum das convenções que indicariam os sentidos de auto-alienação é mapear o próprio conto.

Em "Sôbolos rios que vão", um andarilho perambula pelas beiras de uma cidade, ladeando um morro. Tem o hábito de entender literalmente as palavras que lhe são dirigidas: conselhos, xingamentos. "E as aspirações eram ainda palavras". Restava-lhe, de "uma vida anterior um resíduo de palavras" que "ainda o fazia sentir o peso de certas situações [...]". Esse resíduo de palavras também "[...] ainda lhe provocava a dor que um ódio não desejado não aplacava. "Eternidade, sonho, glória, instantes de cintilação, saltos de crista em crista de ondas de medo e euforia, a imortalidade das estrelas, os abismos da alma, a última convenção de uma harmonia de palavras" (idem, p. 187, grifo meu). A certa altura do conto, o personagem tem um acesso de fúria contra um homem que o ameaça com uma faca. Ele consegue se livrar do homem. Antes, tem encontros sexuais e presencia um velho sendo arrastado por um moreno porque "o velho the fizera propostas indecentes". O moreno se dirige a um policial que tentava um encontro sexual com o andarilho, e o velho é conduzido à delegacia pelo mesmo policial. À convenção de uma harmonia de palavras como eternidade, glória, sensações sublimes e grandiosas, pensamentos elevados e convenções do sublime - lugares-comuns - estão o impulso sexual e sua urgência de satisfação:

\footnotetext{
${ }^{49} \mathrm{O}$ autor-narrador se alienaria de temas difíceis como Auschwitz, e batalha de Salamina e a Guerra de Secessão, mas não expõe seus motivos.
} 
necessidade física, cuja satisfação está a felicidade, mesmo que ilusória, expressa no erro ortográfico "cartaz enorme" que o personagem vê numa barraca, nos arredores do morro onde começa o conto: “CONTE-ME SEUS SONHOS E EU LHE DAREI A CHAVE DO SUCESSO DO FUTURO E DA FELISIDADE [sic]" (Rawet, 2004, p. 185). O andarilho narra ao dono da barraca o único sonho que possuía: "sentado a uma mesa comia pão". O quarentão explodiu numa gargalhada e o homem se ergueu irritado (idem, p. 186). Tudo acaba em briga, e aparece o policial que viria a prender o velho, conforme mencionado. $\mathrm{O}$ sonho sugere claramente a satisfação de necessidades orgânicas, naturais a um ser humano, mas que não bastam para igualá-lo aos animais. A chave do sucesso, do futuro e da felicidade é a satisfação das necessidades mais básicas ou instintivas: comida e sexo. A simplicidade aparente desses dois impulsos humanos necessários à subsistência mínima e ao prazer, seriam portanto inerentes à vida humana - para aquém de um discurso convencional grandioso como manifestação das aspirações mais humanas.

Pelo uso renovador de metáforas mortas, ditos populares e mesmo poema conhecido, percebe-se que há procedimentos próximos ao poético nos contos trabalhados. Cortázar afirma que o texto poético constroi-se por imagens formadas por analogias que apreendam a essência das coisas participadas pelo poeta (i.e., vivenciadas diretamente, numa identificação que o autor associa ao pensamento mágico). O texto rawetiano mostra-se, no entanto, logicamente intrincado e, nesse sentido, distante do pensamento mágico. Mas a realidade, nesses contos, mostra-se carregada de atmosfera onírica e é construída mediante a participação direta do personagem andarilho que desconstrói os lugares-comuns à medida que os vivencia, avançando "à procura de ser" (Cortázar, 2001, p. 97): analogicamente, cumprindo "a forma mágica do princípio de identidade" (idem, p. 95), o andarilho torna-se "um cão que vaga à toa", em "Sôbolos..." quando cede à necessidade de movimento e de auto-expressão pura, sem palavras: "E em certos dias buscava mesmo identificar nos cães qualquer coisa semelhante ao humor. E mesmo nos gatos. Ou nos cavalos. Por isso, porque nem o humor lhe vinha, identificou-se com o cão, mas em vez de um forte latido, um choro, uma inundação de alegria e vitalidade" (Rawet, 2004, p. 183). Ao identificar-se com um cão, o andarilho se dispõe a combinar por analogia (como no pensamento mágico), duas formas de poesia bem distintas:

Mas agora que o bruxo matabelê e Paul Eluard estão separados por toda a extensão da cultura, que nos resta desses estágios iniciais da poesia? 
Fica-nos, virgem como o primeiro dia do homem, a capacidade de admirar. Fica - transladada a um plano metafísico, ontológico - a ânsia de poderio. Tocamos aqui a própria raiz do lírico, que é um ir em direção em direção ao ser, um avançar à procura de ser (Cortázar, 2001, p. 97).

Para Cortázar, o pensamento mágico marca os estágios iniciais da poesia. Entretanto, a ânsia de tomar posse, nomeando ou tentando nomear experiências e objetos, ainda existe e é o que liga o bruxo matabelê a Eluard. Afinal, diz Cortázar, foi "suficientemente provado que a tendência metafórica é lugar-comum do homem, e não atitude privativa da poesia [...] A poesia surge num terreno comum e até vulgar, como o cisne no conto de Andersen [...]" (idem, p. 86).

Lugar-comum, em seu sentido mais abrangente (senso comum, clichê), surge do uso de metáforas na linguagem corrente. Subtraído do âmbito da linguagem comum, as metáforas mortas, desgastadas, tornam-se - valho-me aqui de uma metáfora morta matéria-prima coletada pelo andarilho, nos contos, denunciando sua fonte e sua tendência ao fluxo contínuo e irregular: "a tendência metafórica é lugar-comum do homem, e não atitude privativa da poesia. [...] de certo modo, a linguagem íntegra é metafórica, referendado a tendência humana para a concepção analógica do mundo e o ingresso (poético ou não) das analogias nas formas da linguagem" (idem, p. 86).

Se "cada poema é uma armadilha onde cai um novo fragmento da realidade" (idem, p. 101), então cada conto que, assim como o poema, joga com a palavra e seus sentidos (conceitos, imagens, ambiguidades, campos semânticos), poderia ser uma armadilha. Como exemplo, a derivação de "errância" a "exílio" seria uma armadilha/equívoco perfeitamente verossímil, e que exatamente por isso merece ser considerado nestas análises.

Foi dito que Rawet lança mão de recursos poéticos - líricos - como a metáfora e suas ressignificações, bem como de analogias (homem = cão, em "Crônica..."; Yehuda = Tião, em “Reinvenção...”). E se essa armadilha se valesse de um obstáculo constitutivo que balizaria a interpretação do texto, definindo, de certa forma, os caminhos a serem seguidos pela leitura? No caso específico dos contos enfocados (em especial "Crônica de um vagabundo"), e se o lugar-comum judeu = exílio fosse incorporado negativamente (ou seja, ficasse à sombra do texto), levando-se em conta a origem judaica do autor ${ }^{50}$ e a epígrafe desse conto? Dispondo-se desses dados na análise do texto, poder-se-ia levar em conta a

\footnotetext{
${ }^{50}$ Com base em seus ensaios.
} 
evocação - indireta, mas existente - da figura do Judeu Errante como um mito-fantasma a determinar, pelo avesso, os sentidos do texto ${ }^{51}$. Exercício imaginativo que, como a história de Noé e o Dilúvio em “Kelevim”, mostra-se perfeitamente possível.

A imprecisão própria a "lugar-comum" leva a outra pergunta: o termo consistiria de fato em pontos estáveis nos contos aqui enfocados?

É possível falar em algum tipo de estabilidade nos contos de Rawet, se se considerar que esses contos dialogam com o leitor e sua "tendência metafórica", i. e, sua capacidade metafórica e imaginativa, tornando-o seu "co-autor", ou co-partícipe das andanças dos andarilhos. Os pontos de apoio - lugares-comuns - estariam situados no entremeio entre texto e leitor. Mas esse espaço é ilocalizável, existindo apenas devido ao pacto ficcional entre autor e leitor, que estabelece a credibilidade do texto literário ao fundar espaços imaginários: "como se" correspondessem à realidade, ainda que a autonomia ficcional seja mantida como uma outra realidade. Modos de se tentar apreender o real ${ }^{52}$. A ficção tem, portanto, laço inegável com a realidade, mesmo em narrativas maravilhosas. Entendo que esse laço, nos contos aqui trabalhados, é formado pelos lugares-comuns, imiscuídos no texto, nomeados apenas pontualmente e negociados com o leitor. São como ratos que percorrem os espaços (deslocamentos) mais recônditos e sujos (entrelinhas e subjetividade do personagem) de um lugar (o texto), tendo sua vida (sentidos) condicionada (vida condicionada: sentidos renovados) pela estrutura (textual) criada pelo homem (autor). O vagabundo se alimenta também do restolho dos lugares-comuns.

Assim, não se pode falar em estabilidade, se tomarmos "lugar-comum" como um conceito estável no universo rawetiano, mas sim como um conceito instável, porém, recorrente e comum; recurso estruturador dos contos. Senão, o termo seria reduzido a um de

\footnotetext{
${ }^{51}$ A questão insere-se nas possibilidades abertas pela dinâmica de desconstruções dos lugares-comuns dos próprios contos. Considero aqui a hipótese de se tomar a lenda como mais um lugar-comum a ser atraído para a órbita do conto. A hipótese reforça-se com o uso dos ensaios como textos comparativos de apoio.

52 Segundo Lacan, o real é "uma realidade desejante que é inacessível a qualquer simbolização" (Roudinesco e Plon, 1998, p. 5); "realidade fenomênica que é imanente à representação e impossível de realizar" (idem, p. 31, verbete "real”, grifo meu). Esse conceito é inseparável dos de simbólico ("sistema de representação baseado na linguagem", p. 1, verbete "simbólico") e imaginário ("lugar do eu por excelência com seus fenômenos de ilusão, captação e engodo", idem, p. 47, verbete “imaginário”), formando uma estrutura.
} 
seus sentidos, o de senso comum. Perder-se-ia a riqueza da instabilidade de sentidos que o esmiuçar de rato dos andarilhos estranhos, excêntricos e cômicos ${ }^{53}$, conferem aos contos.

O ponto de partida para esse esmiuçar, ou seja, para um olhar crítico que leia as entrelinhas do conto, seria a superfície sobre a qual se ergue (e lança raízes) o próprio conto e por onde caminham os andarilhos rawetianos, acompanhados passo a passo. Certamente excêntricos pela estranheza que causam ao leitor, que, por sua vez (assim como o narrador), desconhece a identidade desses andarilhos, esses personagens partem de algum lugar indefinido para a margem, cujas denotações e conotações vão se desenhando e criando objetos e locais, ao longo da errância desses personagens solitários. São excêntricos errantes, herois às avessas - anti-herois.

Em “Reinvenção de Lázaro", por exemplo, Yehuda Bitterman, personagem-autor, escreve uma história sobre Tião, trabalhador braçal negro e analfabeto. Para conseguir começar sua história, cuja motivação é clara mas cuja forma é obscura, Yehuda afasta-se de casa, sem rumo definido, e só então passa a ser Tião. As implicações e o modo como essa aproximação é feita serão vistos adiante. A empatia de um personagem-autor judeu com seu personagem negro e pobre ilustra uma postura diante do Outro, a partir desse deslocamento que é principalmente ético:

Assim, do mesmo modo que se pode interpretar as figuras marginais, pobres, loucas, assassinas como sendo a encarnação moderna e brasileira do judeu errante, também podemos ler inversamente que o judeu aculturado dilui seus traços que passam a ser identificados em outros excêntricos e excluídos da sociedade brasileira (Waldman, 2003, p. 84).

Pode-se definir o lugar-comum nos seguintes termos ${ }^{54}$ : em primeiro lugar, o lugarcomum seria veiculado por formas populares "que parecem indicar uma significação coletiva indeterminada que transcende qualquer indivíduo determinado" (Brombert, 2002, p. 43). Se essa "significação coletiva indeterminada" (idem) for compreendida como "signos dialógicos destinados a todos e a ninguém”, segundo Krisinski (2007, p. 29), então se pode

53 "Estranhos, excêntricos e cômicos" são sinônimos para o adjetivo "rato (Dic. Eletr. Houaiss, verbete rato: "adjetivo de dois gêneros e dois números". Estatística: pouco usado. 7 que é estranho, excêntrico, cômico; ratão").

${ }^{54}$ Emprestados de Victor Brombert (2002) em sua análise do anti-heroi de Woyzeck, de Georg Büchner, 1836. 
falar em linguagens transgressivas e subversivas, "que [também] são, ao mesmo tempo, signos precursores de uma conscientização múltipla". Pode-se pensar em literatura engajada, já que se trata de rupturas estéticas compromissadas com um ideal (utopia). Mas o autor prossegue, situando a mencionada conscientização no campo do status único da literatura em meio à linguagem ordinária (construída sobre lugares-comuns): "É a conscientização de uma utopia potencialmente problemática, mas que se realiza como um sonho insistente" (idem). Utopia que por natureza nasce já condenada a ser superada, se o que se propõe não é ruptura com a tradição e seus valores (dentre os quais, os expressos pela linguagem verbal), mas à reinterpretação da tradição visando a algo novo e inevitavelmente instável: sonho insistente porque nunca realizado, mas sempre realizável. Utopia como utopismo cético ${ }^{55}$ manifesto numa literatura em que seu autor "se abstém de conciliar ou julgar, porém procura fornecer ao leitor elementos para ajuizar a refletir. Logo, uma literatura que não produz efeitos sobre a realidade" (Kirschbaum, 2003, p. 219, nota 46, grifo meu). Utopismo cético e ético que se circunscreve à literatura.

Em segundo lugar, o lugar-comum transcende, mas não se descola de sua origem (o sujeito comum) que, ao tomar "emprestadas" essas formas da linguagem, fá-las existir de fato, dando-lhes um contexto e um tom pessoal únicos. Mas isso pode valer tanto para valores elevados (a caridade em "Crônica...”, a grandiosidade buscada pelo andarilho de "Sôbolos...”) como para situações absurdas, como o andarilho de "Sôbolos..." reagindo à expressão "Vá lamber sabão!" lambendo de fato um sabão ${ }^{56}$.

"Lamber sabão" e o clichê relativo à caridade (doar dinheiro a um orfanato, em “Crônica..."57) são traduções visualizáveis do lugar-comum. Tornados visíveis textualmente, nos contos, têm seus fundamentos expostos e, no contexto dos mesmos contos, passam (ou voltam) a ser inusitados - retomam seu sentido puramente referencial. Como eixo dos

\footnotetext{
${ }^{55}$ Como disposição, e não como projeto acabado.

56 “Não sabia explicar exatamente como se dera o primeiro incidente [de idiotice], lembrava-se apenas de que alguém o mandara lamber sabão, e ele tirou da despensa um pedaço de sabão de cozinha, e começou a lambê-lo, com todo o esforço necessário para afastar a repugnância” Rawet, 2004, p. 184).

57 "Procuravam um orfanato, e tinham um embrulho de dinheiro, oferta de uma alma caridosa do interior, mas não sabiam chegar lá. [...] Uma onde irônica percorre-o interiormente, mas não assoma à face. [...] Sim, ele sabia onde fica o orfanato. Se quisessem até poderiam evitar esse incômodo, que ele poderia levar o pacote de dinheiro, porque o doador, numa carta que estava dentro do embrulho pedia aos dirigentes do orfanato que devolvessem certa quantia aos portadores, como reembolso pelas despesas. Sabia disso, perfeitamente. Acontece que ele só tinha dois contos no bolso. Era suficiente?” (idem, pp.
} 228-229). 
contos, o andarilho alinhava esses lugares-comuns reinventados (revisitados e reelaborados) ao longo do conto. Nesse processo de esvaziamento momentâneo, porque necessariamente fugaz, do lugar-comum, as elipses do conto tomam seu lugar, constituindo-se nas fronteiras do sentido, onde os lugares-comuns são reinventados ao longo da leitura do conto. $\mathrm{O}$ movimento de alternância dos pés, no caminhar, torna visível esse processo: na retaguarda, o lugar-comum, na vanguarda, sua reinvenção ou reinterpretação; entre um momento e outro, as elipses. O eixo dos sentidos - o andarilho - desloca-se continuamente, ao sabor dos estímulos e encontros casuais. As fronteiras do sentido deslocam-se com ele.

Ao lado das expressões populares, as informações não digeridas, respondidas irrefletidamente são outra fonte de lugares-comuns. Nos contos trabalhados aqui, esse tipo de reação pode ser percebida na mania de entender tudo literalmente do andarilho de "Sôbolos...", e na auto-entrega do vagabundo a desconhecidos em "Crônica...". Essas informações são assimiladas e transformadas pelos andarilhos, que as refletem nos monólogos interiores presentes nos contos.

Vê-se, portanto, que a busca pelo núcleo distante do lugar-comum passa pela linguagem, e é feita por meio da palavra em suas várias acepções, ambas definidas pelo contexto (i. e., confluência dos fatos). Assume-se, dessa forma, o risco do ridículo, do absurdo e do cômico, a fim de se entrever o que, afinal de contas, é próprio do homem, "essa coisa amorfa, instável, abjeta, gloriosa" (Rawet, 2008, p. 59). Surge então a seguinte questão relativa ao "material com que é feito o homem" (e, por conseguinte, suas manifestações): de que seriam compostas essas formas veiculadoras de sentidos atualizáveis, pequenas narrativas e narrativas incipientes (como as expressões populares)?

A vastidão dos sentidos tomados pela expressão "lugar-comum", conforme será visto mais adiante, já aponta a dificuldade, ou impossibilidade, de se isolar unidades mínimas de significação uniformes ${ }^{58}$. O lugar-comum funcionaria como uma estrutura formada por unidades indecomponíveis porém agrupáveis, unidades essas que se reagrupam ao sabor dos tempos, dos espaços e das idiossincrasias individuais; até onde vai a habilidade do escritor e a astúcia do leitor.

O andarilho de "Sôbolos..." tem uma postura maliciosa diante das situações que enfrenta, a despeito de - ou melhor, exatamente devido a - saber que se espera que ele reaja segundo analogias que revelem (e não criem) qualidades comuns, disponíveis idealmente como repertório da linguagem comum. Os confrontos do andarilho "louco" do conto fazem

\footnotetext{
${ }^{58}$ A palavra é o tijolo com que se constroem os lugares-comuns, mas o que a move?
} 
com que os valores naturalizados e veiculados pela linguagem (ela também em seus sentidos cristalizados) sejam questionados pelo simples espanto do leitor diante do inusitado cumprimento literal da "ordem" de lamber sabão. O espanto, atenuado pela "idiotice" do andarilho, é gatilho extremamente simples que aponta para modificações complexas na estrutura do texto e, potencialmente ${ }^{59}$, na consciência do leitor. A mesma dinâmica (infantil, como no episódio do sabão) está no episódio em que costura o fecho-éclair "no lado oposto à braguilha" (Rawet, 2004, p. 185), a pedido, segundo seu entendimento, do alfaiate: “- Este tipo devia ter um fecho-éclair na bunda - comentou o alfaiate ao ver o homenzinho já longe - e você, se sabe mesmo fazer alguma coisa, toma lá e conserta essa calça" (idem, p. 184). Diante da reação irada do alfaiate que o empregara, maliciosamente "respondeu com o máximo de candura que podia afetar": "O alfaiate passou os olhos pelas calças e deu um murro na mesa ao ver o fecho-éclair aplicado no lado oposto à braguilha. À pergunta sobre o motivo daquilo o homem respondeu com o máximo de candura que podia afetar. Não fora frase sua?" (idem, p. 185). Ao ouvir a ordem seguinte do alfaiate, o andarilho corre, ameaçado: "- Cortem os colhões desse puto!"60.

A idiotice do andarilho leva-o do grotesco ao sublime: do entendimento literal da linguagem figurada ("Esse tipo devia ter um fecho-éclair na bunda") à reflexão sobre hábitos e intolerância. O espanto do alfaiate (e do leitor) é descrito, mas não esgotado ${ }^{61}$, nas seguintes palavras:

A gratuidade da linguagem, o choque com tudo aquilo que está um pouco fora de uma pequena faixa de hábitos, a possibilidade de suportar uma ação grotesca, a impossibilidade de suportar o que parece uma atitude ridícula, o lado elementar de paixões a ditar normas impossíveis de serem seguidas sem uma consequente perturbação (idem, loc. cit.).

"[G]ratuidade da linguagem": ao mesmo tempo em que o narrador fala em "sintomas de idiotice" (Rawet, 2004, p. 184), o andarilho faz pensar numa verossímil e

\footnotetext{
${ }^{59}$ Talvez como "efeito colateral", já que não é essa a intenção explícita desse autor que "escrevia para poucos", nem objetivo prático. O efeito no leitor é claramente pensado, mas como consequência natural de elaboração literária.

${ }^{60} \mathrm{O}$ humor da frase está compreendê-la literalmente ou figuradamente - tanto faz uma forma ou outra, depois do incidente da calça.

${ }^{61}$ Ao contrário, o espanto contamina todo o texto.
} 
possível gratuidade dos sentidos estabelecidos pelo senso comum, como se aquela fosse um espelho deste. Se não fosse capaz de, em sua idiotice, refletir o juízo que cai sobre ele mesmo, a consequência da atitude do andarilho seria a rejeição do senso comum pela idiotice opaca ${ }^{62}$ que transmutaria a rejeição em ódio. No entanto, o andarilho não parece querer destruir, mas reformular seus valores, ou seja, insistir em sua participação ativa no senso comum, sinalizado pelo fechar de olhos em meio à escuridão, no final do conto e mais explicitamente pelo "reencontro inadiável"63 com seus temores da infância.

O reflexo ofuscante do senso comum passa, portanto, pelo lugar-comum expresso pelo clichê infantil e pela expressão popular. O espanto diante da reação do andarilho repercute indiretamente no leitor. Além do episódio do "lamber sabão", pode-se apontar o clichê do medo infantil do escuro, também no final do conto: o medo infantil torna-se revela-se - consciência obscura ("de noite") dos próprios temores instintivos. O cão se transformaria em lobisomem e imediatamente, por um momento, em homem:

Segundos depois se punha em marcha de novo, ladeira abaixo. E no canto de uma calçada, junto a um edifício em construção, deitou-se. Precisava dormir. Tinha sono. E só antes de adormecer, já com as pálpebras quase juntas percebeu que ele era o sonho de um outro, de um outro homem, talvez (Rawet, 2004, p. 190).

"Sôbolos rios que vão" é um conto cheio de imagens, mas também constroi um discurso basicamente linear devido à natureza do texto escrito, porém tortuoso em que, por meio da estrutura do conto (suas elipses, foco narrativo e figuras de linguagem), cria-se uma estrutura extremamente sólida porém lábil, apesar de aparentemente frágil, sem nunca enrijecer-se. Até porque essa realidade renova-se a cada leitura, impedindo que o texto se torne rígido e refém de chaves interpretativas, como seria um texto alegórico, por exemplo ${ }^{64}$.

\footnotetext{
${ }^{62}$ Entendida como limitação cognitiva, despida de ingenuidade; não se tem mais um "palhaço", mas apenas um sujeito medíocre.

63 A ideia de retorno em "reencontro" é explícita, mas não o alvo: reencontro com quem/com o quê? Consigo mesmo. A simplicidade das reações do andarilho camufla a complexidade de suas consequências para si mesmo (e, por extensão, para o outro).

${ }^{64}$ Rawet dá a entender que o leitor visado por seus contos não é necessariamente o erudito, mas o sujeito comum, contemporâneo e conterrâneo, ou mesmo qualquer outra forma de familiaridade possível
} 
Com essa "brincadeira-jogo" de sentidos e significados, Rawet aponta para a validade da ficção para além do texto (função ética da literatura como linha de força da ficção rawetiana) e para as possibilidades subversivas ${ }^{65}$ no/por meio do lugar-comum em seu sentido mais amplo, nos termos delimitados neste trabalho. Revolve-se o material de que são feitos a linguagem e os sonhos dos personagens.

Delimita-se, portanto, um espaço comum, formado pela linguagem, de saberes depositados no texto literário, revivificados pela leitura do mesmo e compartilhados idealmente, pela comunidade imaginária (e extremamente imprecisa ${ }^{66}$ ) formada pelos leitores que compartilhem do universo de referências de Rawet, desde o simples domínio instrumental da língua portuguesa falada no Brasil (com a qual o autor constroi sua linguagem) até o leitor carioca conhecedor dos lugares por onde o vagabundo rawetiano transita com familiaridade.

Um mesmo universo de referências concretas que se funda na linguagem é, portanto, espaço compartilhado tanto pelo leitor dos contos de Rawet como pelo próprio autor, estabelecendo algum tipo de familiaridade e comunidade extremamente abstrata, mas verossímil, entre Rawet e seus leitores. Familiaridade esta que não pressupõe nenhum conhecimento prévio sobre o autor, como sua biografia ou sua produção ensaística, para uma leitura produtiva de sua ficção. Cabe ao leitor identificar os lugares-comuns, que são apenas insinuados ou insidiosamente nomeados ${ }^{67}$.

\section{Ensaios e biografia}

\section{É memória sim. Mas de cadeia.}

(Graciliano Ramos citado por Ricardo Ramos)

(imigrante, judeu, homossexual, ou mesmo o erudito). O universo de leitores que se infere nos ensaios e entrevistas de Rawet podem dizer algo sobre seu projeto literário.

${ }^{65}$ Subverter no sentido de revolver: "lat. subverto, is,ti,sum,tère 'transtornar, revolver etc."'. Fonte: Dic. Eletrônico Houaiss.

${ }^{66}$ Faço referência a essa comunidade abstrata para que seja possível sistematizar as linhas de força que perpassam o lugar-comum em alguns contos de Rawet. Assim, tem-se os leitores “capacitados” de Rawet, os contos e, por fim, os lugares-comuns que marcam a intersecção entre autor (i.e, texto literário) e leitores (i.e, leituras possíveis do texto literário).

${ }^{67}$ Assim, por exemplo, em "O casamento de Bluma Schwarts", os gestos que Bluma percebe como lugares-comuns o são enquanto clichês amorosos, mas podem ser vistos também como clichês folhetinescos. 
A epígrafe deste capítulo foi tirada da biografia de Graciliano Ramos por seu filho Ricardo em Graciliano Ramos: retrato fragmentado (Ramos, 2011, p. 75). Ricardo refere-se a uma conversa sobre Memórias do cárcere, em processo de escrita, que o faz pensar sobre o gênero (ficção ou memórias) do livro: “E aquilo, afinal, era memória ou ficção?” (idem).

Ricardo Ramos fala que eram "território vasto" na obra de Graciliano as intenções "que ficam na sombra e pouco se revelam": "Creio que todos nós, perturbados pela literatura, muitas vezes nos interrogamos sobre as intenções do autor. Não me refiro às centrais, mais ou menos óbvias, mas às secundárias e, particularmente, àquelas que ficam na sombra e pouco se revelam" (idem, p. 134). Ficam à espreita, e não são óbvias nem simples, mas estão conectadas em rede e ajudam a entender o que se pode entender, na citação de $\mathrm{R}$. Ramos, por "intenções do escritor": "Porque as intenções do escritor formam uma teia, às vezes de superfície, às vezes subterrânea, com uma indisfarçável harmonia. No seu desenho, que amarra os tempos do entrecho; na sua textura, que dá profundidade às personagens" (idem, loc. cit.).

Por um lado, falar em intenções do escritor, além das óbvias, seria ingenuidade, em se tratando de obra não-engajada politicamente. Por outro lado, o que se chama de intenções do escritor pode ser visto não como um traço ou marca perfeitamente delineados numa obra de ficção, mas, antes, como um conjunto de traços mais ou menos identificáveis numa determinada obra, se for levada em conta comparativamente ao conjunto da obra de um autor. Refere-se mais propriamente a seu estilo e sua habilidade literária. Na biografia de Graciliano Ramos, Ricardo Ramos fala em "teia de intenções", às vezes submersa, outra na superfície do texto. Ao se perguntar, num primeiro momento da leitura, pelas "intenções do escritor", o leitor está, na verdade, expondo suas próprias expectativas em relação ao texto e perguntando-se pela melhor maneira de interpretá-lo diante das questões que se lhe impoem.

Da mesma forma, ao se perguntar se algum traço ficcional é motivado pela biografia do autor (o cargo de Rawet como engenheiro e sua ocupação literária explicando o autor-narrador de "Kelevim", por exemplo), o leitor inevitavelmente se refere a uma ficção: o autor efetivo e sua assinatura:

Assinar significa inscrever na obra o nome próprio - em princípio o nome civil, mas não necessariamente -, numa operação de eficácia dupla: por um lado, indicação e reivindicação de origem, de paternidade, de 
responsabilidade; por outro, possibilidade de curso próprio libertado da origem e fora do alcance da paternidade (Baptista, 2003, p. 10).

Não se trata de procurar o autor no texto, na medida em que o texto é que definiria as linhas de força a serem procuradas, e não a biografia do autor. Dessa forma, "Kelevim" é apenas uma tentativa abortada de se construir um espaço textual; analogamente, em "Diário de um candango" Rawet diz que ainda não haveria literatura que tivesse Brasília como cenário, pois Brasília ainda não teria seu autor de ficção (apenas um escritor, Marques da Silva): não existiria literariamente ${ }^{68}$.

O que se busca ao trazer à tona, a partir do texto, elementos que se projetem, como linhas de força, para a figura do autor efetivo, não é memória documental ou pessoal em correspondência fiel aos fatos. Busca-se, na verdade, a figura "fictícia" do autor por trás de sua assinatura como autor efetivo do conto (e o autor por trás do autor de "Kelevim") 69 . Metaforicamente, existiria a distância textual entre Rawet e seus andarilhos solitários ("wandering loners") que o leitor - e só o leitor - poderia traçar, pois não é o andarilho rawetiano nem Rawet: é apenas um dos leitores de Rawet ${ }^{70}$.

A biografia de um autor é um dos fantasmas que assombram o texto literário de Graciliano e de Rawet. Isso posto, em relação a Rawet pode-se pensar numa série (finita, porém) de combinações dos traços de identidade apreendidos a partir dos ensaios: judeuengenheiro-escritor, boêmio-homossexual, judeu-boêmio, etc., em ordens também variáveis. Levar em conta a auto-imagem (construída nos ensaios) do autor seria vã se se detivesse apenas na identificação e nomeação desses traços, e de qual se sobrepõe a qual em determinada combinação. Entretanto, levar em consideração a existência de traços identitários mais ou menos identificáveis ou nomeáveis nos ensaios rawetianos pode ser

\footnotetext{
${ }^{68}$ Rawet teria procurado pelo autor por trás da assinatura do livro Diário de um candango, mas se referiria à obra descolada de sua origem, "fora do alcance da paternidade", ao se perguntar: "quando é que surgirá um autor de Brasília?” (Rawet, 2008, p. 163).

${ }^{69}$ Poderia aumentar ainda mais o nível de abstração do abismo identitário, partindo do andarilho e continuando a mirar o abismo: o imigrante por trás do autor, o judeu por trás do imigrante etc. Todos são recortes identitários válidos não por si sós, mas em textos e abordagens diferentes.

${ }^{70}$ Por isso, o leitor pode identificar em Yehuda Bitterman, personagem central de "Reinvenção de Lázaro", "uma referência de alguém prisioneiro de uma condição judaica que o despedaça”, com o Rawet-autor, “dividido entre o judaísmo 'abstrato', essencialmente ético [...], e uma experiência 'concreta', girando em torno de interesses materiais [...]”' (Kirschbaum, 2010, p. 43).
} 
proveitoso no sentido de se vislumbrar as linhas de força que se entrecruzam formando o que R. Ramos chama de "teia de intenções". Para tanto, concentro-me nos ensaios sobre escritores que chamavam a atenção de Rawet: Clarice Lispector e Renard Perez.

É necessário esclarecer que entendo por “intenções do escritor" a relação que se pode estabelecer entre a figura do autor e um recorte feito no conjunto de sua obra. Isso pode ser ilustrado de outra forma, como na comparação feita em um ensaio sobre Irmãos da noite (Renard Perez) intitulado "Irmãos da Noite do irmão da noite Renard Perez" (1979, in Rawet, 2008), Rawet, após enumerar experiências noturnas próprias, propõe a comparação entre uma "obra" de um burro e uma obra de Kandinski:

Não, não se pode distinguir à primeira vista um quadro de Kandinski de um pintado por um burro com um pincel amarrado no rabo. Mas, mesmo sem se preocupar com obras completas, o interessado procura conhecer outras coisas do artista, depoimentos pessoais, atitudes em relação às coisas, fragmentos que completam uma certa imagem que se tem dele. No fim de algum tempo não é muito difícil perceber onde está o artista, e onde o coice do burro (idem, p. 251).

A comparação hipotética fica mais clara quando se toma o ensaio sobre $A$ hora $d a$ estrela (C. Lispector) no ensaio "A Hora da Estrela ou as frutas do Frota, ou um ensaio de crítica literária policial ", de1979 (in Rawet, 2008, pp. 217-224). Nesse ensaio, Rawet relaciona arte e consciência (intenção), e fala em "crítica literária policial”: "crítica literária servindo de base à ação policial, a descoberta de um, [sic] assassino, ou de vários, tendo como base apenas uma obra de ficção” (idem, p. 220). Em tom de provocação, o autor propõe que a crítica literária feita sobre uma obra ficcional específica seja usada para análises de casos policiais. Destrinchando a provocação, podem-se ver algumas concepções sobre crítica literária. Como pressuposto, a obra de ficção deve ser vista como efabulação, acima de tudo ${ }^{71}$.

Claramente, o campo de investigação da crítica formulada por Rawet é delimitado: a obra de ficção. Isso exclui dados biográficos, textos de apoio ou quaisquer dados que não tenham deixado seus traços no texto. Uma análise arqueológica do texto literário seria

\footnotetext{
${ }^{71}$ Isto é, elaboração do real inapreensível, em seu ponto de intersecção com o simbólico e o imaginário lacanianos.
} 
possível, mas não tanto produtiva quanto a análise das relações de força estabelecidas entre os elementos do texto (ambiguidades, elipses etc.). Podem-se estabelecer filiações literárias, intertextos, influências declaradas ou imiscuídas, de forma a conformar o cânone no qual se vê o autor. Ou mesmo a posição singular que ocupa à margem ou no centro desse cânone, ou seja, a relação e as afinidades com (ou peculiaridades em relação a) seus contemporâneos.

Olhando de fora do texto, do ponto de vista do autor que reflete sobre sua obra, Cortázar afirma: "O que está antes é o escritor, com sua carga de valores humanos e literários, com a sua vontade de fazer uma obra que tenha sentido" - ou que brinque e jogue com o sentido, no caso de Rawet (e Clarice, segundo o próprio). Seguindo com a citação de Cortázar (2011, p. 156): “o que está depois é o trabalho literário do tema, a forma pela qual o contista, em face do tema, o ataca e situa verbal e estilisticamente, estrutura-o em forma de conto, projetando-o em último termo em direção a algo que excede o próprio conto" (grifos meus). Olhando de dentro do texto, o leitor move-se num espaço textualmente estabelecido. Segundo regras estabelecidas, como se fosse um personagem hipotético do conto, ele participa hipoteticamente dos desafios enfrentados e propostos pelo autor. Sobre isso, diz Horacio Quiroga, no décimo mandamento do "perfeito contista" (citado também por Cortázar, no volume de ensaios mencionado): “Ao escrever, $[\ldots]$ [c]onta como se teu relato não tivesse interesse senão para o pequeno mundo de teus personagens e como se tu mesmo fosses um deles, pois somente assim obtém-se a vida num conto" (Faraco (org.), 1999, p. $75)$.

$\mathrm{Na}$ chamada "crítica literária policial", de acordo com a imagem criada jocosamente - assim como o decálogo de Quiroga - por Rawet,, as pistas (relações entre os dados textuais e suas implicâncias) e os suspeitos (os personagens: quem faz o quê) do crime (os sentidos do texto e suas inscrições), assim como o próprio crime, estariam, a rigor, apenas na obra. A "crítica literária policial” vislumbra a passagem do "estado pré-agônico" o primeiro momento, não conceituável, da reação ao deboche alheio (nem sempre explícito) - ao "estado agônico" no qual se produz a obra em si: registro de momentos únicos da consciência, em termos formulados por Rawet nos ensaios referidos. Biografia e contexto, segundo essa abordagem, seriam apenas algumas dessas marcas não-determinantes por si mesmas. Assim, uma arqueologia da obra de arte, num âmbito geral, é perfeitamente possível e verossímil; o que realmente importa para o "crítico literário policial", entretanto, é a superfície sobre a qual se erguem as estruturas do conto e se traçam seus espaços de circulação. É sobre a superfície que se dão as negociações entre personagem e cenário, e 
(analogamente, talvez) entre leitor e texto. Nessa superfície, Rawet diz distinguir "duas correntes principais na prosa brasileira: uma aborda a problemática da criação, a outra, a criação da problemática" (Rawet, 2008, p. 172). Clarice, afirma Rawer, "paira soberanamente na primeira" abordagem, enquanto "Renard Perez, com Chão Galego ${ }^{72}$, se agiganta na segunda",73: "Chão galego, viagem dupla de Renard Perez, antiviagem, não viagem, mergulho na própria biografia, prosa madura de um escritor maduro, lembra o melhor Graciliano de Infância" (idem, p. 171). É curioso notar que a "criação da problemática" passa pelo equívoco primário, fruto talvez de um clichê que associa automaticamente a Espanha à dança flamenca:

Acabamos voltando para o hotel. Mas é cedo demais para nos recolhermos e na portaria insisto, quase patético, na indagação: onde há, em Vigo [cidade galega] um lugar típico para ir? Um tablado flamengo [sic], qualquer coisa no gênero, essencialmente espanhola? A resposta do moço vem num tom quase agressivo, é como se eu tivesse indagado uma monstruosidade: "- Claro que aça no existe nada de eso" - E continua, na maior brutalidade: “ - Entonces piensas usted que aça es Andaluzia, donde toda la gente es gitano y vive em las calles a cantar?" (Perez, 1972, p. 13).

A expectativa de turista mal-informado é superada logo em seguida, quando o mesmo garçom grosseiro abre-lhe as portas da cultura galega, nesse início de viagem em busca dos parentes paternos: "Depois, volta a si da explosão e, mais moderado, concede em explicar que somente em ocasiões muito especiais é que o galego toca e canta suas músicas" (idem, loc. cit.).

Já em "A hora da estrela ou a frutas do Frota...", Rawet afirma que em Clarice é redescoberto o potencial da palavra enquanto linguagem: "Há em seu livro [A hora da estrela] a clareza, a transparência, como que uma redescoberta da palavra em sua função de linguagem [...]" (Rawet, 2008, p. 222, grifo no original). Na mesma frase, o autor continua, esclarecendo que essa redescoberta da palavra é um esforço deliberado e necessário,

\footnotetext{
72 A obra é de 1972; o ensaio, intitulado “Chão galego - A dupla viagem de Renard Perez”, é do mesmo ano.

${ }^{73}$ Clarice, pairando sobre a problemática da criação, aproxima-se de Rawet e sua metaescrita impregnada de imprecisões, dualidades, ambiguidades e elipses - pairando sobre a superfície do texto.
} 
segundo necessidades pessoais e em razão da natureza do trabalho literário (em particular o ficcional): "[a clareza, a transparência é] coisa talvez desconhecida por Clarice em sua infância e adolescência, no ambiente familiar, mas apreendida no meio não-familiar. E Clarice é nordestina". Como recurso, vale-se de "um humor na fronteira do horror" da "realidade maior" "intuída ou pressentida":

A sequência de títulos [de $A$ hora da estrela] me dá ideia de uma tentativa lúdica em estado agônico, quando uma realidade maior é intuída ou pressentida, não o lúdico infantil da despreocupação, mas um lúdico feito, ao contrário, de preocupação, num estado que não pode definir, porque escapa ao formulável, e que beira um humor na fronteira do horror" (Rawet, 2008, p. $222)^{74}$.

Ludicamente, Clarice tentaria, no romance em questão, condensar a experiência pessoal e as observações num instantâneo provocado pelo deboche alheio e registrado em estado agônico, na forma de autodeboche ${ }^{75}$ - como reação que se vale do mesmo recurso (o humor), em direção ao mesmo alvo do deboche (a autora): "E só a grandeza da escritora conseguiu uma feição estética de altíssimo nível, num livro que é uma espécie de autodeboche de quem sabe, mas ignora, e se não ignora, não sabe o que fazer (idem, p. 221)".

Desestabiliza-se a linguagem usada para, com o mesmo material linguístico - a palavra e suas denotações e conotações -, erguer-se uma linguagem revitalizada. O resultado é o impacto estético da obra sobre o senso comum artístico ${ }^{76}$, que tende a permanecer-lhe hostil, ao menos num primeiro momento ${ }^{77}$.

Em seguida, Rawet traça um panorama do impacto de $A$ hora... no meio hostil (debochado) que, paradoxalmente, o produziu, ao provocar a resposta da autora ${ }^{78}$. Sobre isso, algumas observações são feitas ao longo da citação a seguir (Rawet, 2008, p 221):

\footnotetext{
${ }^{74}$ Ludismo que faz pensar no clown becketiano por lembrar o inexprimível, talvez.

${ }^{75} \mathrm{O}$ termo é usado pelo próprio Rawet.

${ }^{76}$ Impacto esse que, em Rawet, concentra-se no espaço (instável) de negociações de sentido entre o leitor e o texto.

77 Até que se entre para o cânone local ou, num momento posterior, livre-se de amarras conceituais.

${ }^{78}$ Segue a citação pontuada por observações minhas.
} 
A hora da estrela, de Clarice Lispector, me chocou como uma das mais altas expressões de equilíbrio obtido em desequilíbrio total [i.e., tensão seguida de resposta, sentida como necessária e não necessariamente conceituável, por parte do autor; autodeboche obtido a partir do deboche. Grifos meus], provocado, forjado, por um bando de terroristas, vigaristas, moleques de deboche, faturando alto não com atividade apregoadas, mas com outras [grifo no original; Rawet entende que, em $A$ hora... Clarice põe as segundas intenções (entendidas como auto-promoção, gratuidade/ineficiência e vigarice) em seus devidos lugares ao trazer a preocupação com valores estritamente literários (forma, expressão, linguagem) de volta ao primeiro plano; traz também a imaturidade e o patrulhamento ideológico desses debochados]. É uma acusação que faço.

Para Rawet, a literatura e a arte feitas na época, de um modo geral, não passariam de um "ballet de ratos, lixo do esgoto com uma semelhança formal que nos confunde" ( $\mathrm{p}$. 224); "quadradinhos, risquinhos, manchinhas!"; "manchinhas, risquinhos, gritinhos" (p. 252) e toda forma de "embromação" e "vigarice" na arte e no conto modernos (p. 251).

Assim, em "O profeta" (in Contos do imigrante), por exemplo, o leitor pode ou não saber identificar questões importantes para a interpretação do conto, como a Shoá e o tema do exílio e auto-exílio em Rawet, que também podem trazer informações sobre a visão do autor sobre a chamada literatura de Holocausto e sua transformação do horror em apenas mais um thriller literário comovente mas inofensivo ${ }^{79}$ :

Esquecer o acontecido, nunca. Mas como amesquinhá-lo, tirar-lhe a essência do horror ante uma mesa bem posta, ou um chá tomado entre finas almofadas e macias poltronas? Os olhos ávidos e inquiridores que o rodeavam não teriam ouvido e visto o bastante para também se horrorizarem e com ele participar dos silêncios? Um mundo só. Supunha encontrar aquém-mar o conforto dos que como ele haviam sofrido, mas que o acaso pusera, marginalmente, a salvo do pior. E consciente disso partilhariam com ele em

\footnotetext{
${ }^{79}$ O próprio autor traz a questão em "Kelevim", ao mencionar a "cafetinagem histórica que se faz com Auschwitz" (p. 205). O tema também é tratado na peça inédita "O lance de dados", analisada por Waldman (2010).
} 
humildade o encontro. Vislumbrou, porém, um ligeiro engano (Rawet, 2004, p. 26, grifos meus).

"Um mundo só" revela-se ao profeta, no âmbito de sua própria família, a cisão entre seu mundo e o dos bem adaptados familiares - equivalente à distância entre os malvistos judeus do leste europeu e os judeus germanizados de Berlim e Viena. Assim, o clichê do judeu barbudo de capote, imigrante aparentemente monoglota no país de chegada, pode ser entendido como um ponto de partida para que se questione o uma suposta homogeneidade judaica, ao lançar um olhar sobre as tensões entre assimilação (adaptação) e a coesão comunitária (que resvala para a questão identitária) entre os imigrantes (judeus, em especial) no Brasil. O que seria interpretado, pelos sinais aparentes, como um "típico" e anedótico judeu do leste europeu, em "O profeta" sugere, por meio do estranhamento intrafamiliar, um sujeito com individualidade apenas insinuada no conto ${ }^{80}$.

Retomando a comparação entre Kandinski e o burro (ou melhor, entre uma obra e uma "obra"), do ensaio sobre Irmãos da noite (Renard Perez), vê-se que a tela de Kandinski diferencia-se da tela do burro pela existência do entremeio entre fruidor e a tela dotada de apelos, intenções e gestos que dialogam com esse fruidor ao partir do autor. O tripé artistaentremeio-fruidor desaba quando o burro se dá conta de que tem um pincel preso ao rabo e escoiceia a tela, e não existe efetivamente enquanto o burro balança seu rabo, alheio a quem lhe prega uma peça.

$$
* * *
$$

Diante do foi exposto, pode-se dizer que a consciência do lugar-comum, em Rawet, é sinal de lucidez. Em "Crônica de um vagabundo", a lucidez do personagem torna-o diferente ao conferir-lhe um olhar que o diferencia dos demais - do sujeito comum com o qual partilha o repertório de lugares-comuns, mas não a consciência de sua artificialidade. Ao mesmo tempo, esse vagabundo lúcido tem pouquíssimas particularidades, indicadas pelos pertences comuns que carrega numa maleta, o que o torna um sujeito indiferenciado: comum. Sua lucidez, no entanto, permite-lhe romper barreiras que o sujeito médio não se permite. Essa barreira é indicada por uma metáfora morta, lugar-comum do autoconhecimento: o mergulhar em si mesmo:

\footnotetext{
${ }^{80} \mathrm{O}$ tratamento dado ao tema confere ineditismo ao autor.
} 
Cumpria o destino que quase todos cumprem, e que só a uns poucos é evitado, esses que nunca duvidam de um único gesto ou palavra, que têm a rara felicidade de um desconhecimento absoluto. Os outros, os que ousam se conhecer realmente, adquirem o hábito do terror proporcional à intensidade da descida em si mesmo. Alguns ainda se iludem. Recebem como explicação um farrapo de ideia e uma distorção que permite uma volta à tona da tranquilidade. Ele ousara ir mais longe, no dia em que compreendeu que o que havia de mais profundo naquilo que tentavam lhe explicar era chão e inconsistente, era uma contrafação de densidade, uma água de cheiro para inocentes. O que era lhe ministrado como o supra-sumo dos remédios humanos lhe surgiu de repente com a sua capa de fragilidade e inconsistência. $\mathrm{E}$ de repente percebeu que havia uma inversão. O que era tido como aparente, secundário, era o mais importante (Rawet, 2004, p. 212-3, grifos meus).

O narrador olha através do personagem e revela parte de seus pensamentos. Para tanto, usa de imagens simples, oposições perfeitamente visualizáveis e compreensíveis em suas oposições: superfície/profundidade, essencial/supérfluo, principal/secundário. $\mathrm{O}$ tratamento que se dá a essas oposições, verdadeiras metáforas mortas, no entanto, renova-as, ao inverter-lhes os sentidos, conforme indicado ao final da citação acima. Como se daria essa renovação?

A percepção de uma inversão aparentemente simples dá o impulso para esse processo: O que se toma por principal é, na verdade, secundário, e vice-versa. A percepção dessa ilusão tão comum guiará o andarilho em sua errância. Por extensão, as expectativas do vagabundo provocam no leitor as suas próprias: a que se referem as oposições acima mencionadas, as quais cobrem um campo coberto por enormes elipses ${ }^{81}$ ? Como elas se dão? Como serão confrontadas com a casualidade da errância do vagabundo?

O imigrante inadaptado, aparentemente estereotipado, que se decide voltar para sua terra de origem, em "O profeta" (1956), torna-se o andarilho anônimo, pouco caracterizado e (salvo as diferenças) não menos inadaptado, que se deixa levar por suas inquietações e vaga

\footnotetext{
${ }^{81}$ A pergunta desdobra-se na seguinte: Essas elipses referem-se apenas a um processo tortuoso de autoconhecimento, descrito ao longo do conto, ou se refere também a valores éticos, percepção do mundo, exílio/auto-exílio e outras questões tão próximas entre si quanto abrangentes?
} 
pela cidade e seus cantos escuros de Os sete sonhos (1967). O leitor é logo apresentado às densas reflexões, no início do conto, e à carga de experiências e expectativas do vagabundo que leva consigo o leitor em sua "atenção orientada, sempre em movimento" (Rawet, 2004, p. 212).

\section{6. "Crônica de um vagabundo"}

A trama de "Crônica de um vagabundo", publicado pela primeira vez em 1967 no livro Os sete sonhos, pode ser resumida em poucas palavras: um homem chega de ônibus a uma rodoviária, sai andando, encontra pessoas, reage a elas e às circunstâncias, volta para a rodoviária e entra num ônibus. O vagabundo do conto é o andarilho ("aquele que vaga"), e não carrega em si, essencialmente, nenhum sentido pejorativo. Não se trata, como também pode parecer, de uma elite de vagabundos-filósofos, mas de uma elite de corajosos que recusam as respostas prontas e enfrentam seus medos, segundo o próprio conto. Como já foi 
mencionado, ele é, antes de tudo, um homem comum. $\mathrm{O}$ andarilho rawetiano é, como o flâneur, um subversivo: "Le flâneur est subversif. Il subvertit la foule, la marchandise et a ville, ainsi que leurs valeurs" ${ }^{\prime 82}$ (Gros, 2009, p 238) ${ }^{83}$. Passo a passo, o andarilho toma para si o lugar-comum e o transforma, superando-o, sucessivamente ${ }^{84}$. A experiência interior do andarilho (em relação à qual o leitor tem parte ativa) funde-se com a percepção da cidade, pelo próprio vagabundo. Ele segue passos que em algum momento já foram traçados por outros, mas que, em sua errância, tornam única sua caminhada, entregando-se assim ao acaso e à experimentação. O vagabundo vivencia a cidade e seus personagens anônimos e marginais, em locais muitas vezes escuros e fechados (um cinema, um beco, um porto na madrugada etc.).

O espaço de sua experimentação é, portanto, claramente delineado: a cidade. Os atores dessa experimentação na cidade são seus habitantes: a prostituta, a velha doente (“Crônica...”); o alfaiate, o assaltante (“Sôbolos...”); vizinhos vindos da praia, os entoadores de uma cantilena, na sinagoga ("Reinvenção...") ${ }^{85}$. O vagabundo inicia sua própria história pronunciando: "Era uma vez um vagabundo" (Rawet, 2004, p. 211).

Sente-se desconfortável devido à viagem de ônibus, o que o faz pensar na necessidade de repouso numa cama. Segue "em passadas firmes ${ }^{86}$, sem desvios de atenção nem rompantes de ódio": segue concentrado em sua meta. Qual? "A necessidade de movimento projetava-o como se estivesse determinado em seus propósitos” (Rawet, 2004, p. 211, grifos meus). O que o faz seguir em passadas firmes são, portanto, propósitos que o impelem ao movimento. Quais são esses propósitos? Não se diz a princípio. Serão revelados ao longo de sua caminhada - ao longo do conto. O amargor e o ódio são combustíveis para a

\footnotetext{
${ }^{82}$ Pode-se lembrar do vagabundo de "Crônica..." em sua errância pelos espaços escuros da cidade, pela "caridade" cínica ou caricata e por sua maleta quase vazia.

${ }^{83}$ Mais adiante, Gros define subversão tendo em vista o "flâneur das cidades": "La subversion, c'est ne pas de s'opposer, mais de contourner, détourner, exagérer jusqu'à altérer, accepter jusqu'à depasser" (idem, grifo meu)

${ }^{84}$ Não é exatamente desprezo pelos valores o que move o andarilho em Rawet, mas a busca pelo elementar que esses valores encobriram, sufocando-os. Num primeiro momento, essa postura parece cínica em seu sentido original, que é o de mergulhar nas coisas e de lá tirar o "elementar "-ainda mais cru que "necessário" e além de "útil" (idem, p. 182).

${ }^{85}$ Já o personagem semi-inventado (esboçado) da inventada Kelevim aponta ausência de alteridade minimamente constatável, porque apenas indica um esboço de vínculo com o autor-narrador, e um vínculo recém-inaugurado com a cidade Kelevim.

${ }^{86}$ O conto também termina "com os passos seguros" (idem, p. 243).
} 
errância determinada do vagabundo, ao mesmo tempo em que funcionam como filtros da consciência:

Seu ódio deve ter adquirido a consistência das coisas permanentes. Não necessitava mais de objetos pessoais ou circunstâncias que precipitassem sua aparição. Incorporara-se-lhe, fazia parte de seus gestos e sorrisos, e não podia deixar de reconhecer que era um estimulante forte para a ação (idem, pp. 211-212, grifo meu).

"Deve ter": suposição que, espera-se, vai ser posta à prova. Todas as marcas de indeterminação do conto, destacadas no parágrafo acima, parecem indicar intenções subjetivas imprecisas, porque apenas supostas, que reverberam pelo conto, e por isso devem parecer claras em suas imprecisões: o ódio do vagabundo tem realmente a consistência das coisas permanentes? Quais são os propósitos que o impelem a uma caminhada (movimento) determinada? Sabe-se de antemão que a caminhada em si é prova de fogo para sua indiferença aos valores que deslizam sobre a superfície onírica do conto.

A realidade - o "mundo próprio que não se coaduna com as palavras, nem com as sutilezas ${ }^{87}$ - nunca é um ideal a ser alcançado, mas, antes, algo a ser concomitantemente redescoberta e construída como experiência estética vivida. Não se "coaduna com as palavras, nem com as sutilezas, mas com a ação bruta, encerrada em ganga e escória de hábitos e afetos" (idem, p. 215). A redescoberta e construção da realidade são, então, ações indizíveis? Talvez não sejam ações exprimíveis plenamente com palavras; o recurso às palavras, mesmo as que descrevem imagens do mundo exterior, aponta para o material de que são feitas, ou seja, seus fundamentos na realidade a que representa. Vislumbra-se um espaço pré-verbal, feito de ações em potencial, que é passagem obrigatória para a nomeação. Nesse espaço, o sonho traz recursos para a construção do "mundo próprio" do vagabundo.

Um mecanismo de espraiamento dos sentidos, por meio de conotações que as palavras recebem em seu contexto, perpassa o conto todo. A palavra é posta em ação e movimento: não apenas significa, mas agrega e desloca os significados, para depois ir montando os sentidos do texto, como demonstrado acima. Esse recurso, meticuloso em sua construção, dá ares de poesia em estado bruto aos devaneios do vagabundo. Cada confronto

\footnotetext{
87 "Mundo animal" (idem, p. 215) e "mundo interno" são outras expressões referidas ao andarilho, presentes no conto.
} 
com a realidade, na forma dos encontros tidos ao acaso e ao longo da errância pela cidade, é o estopim e o núcleo (funcionando como contexto definidor) de cada movimento de questionamento das convenções a que as palavras cristalizadas se servem. Em cada núcleo, é possível delimitar subnúcleos do conto (cujo núcleo, ou mais propriamente um eixo, é o próprio vagabundo) $)^{88}$. Os catalisadores dessas transformações desconstrutivas e reconstruidoras de sentidos são o ódio e o amargor, acima mencionado, e a animalidade, definida logo no começo do conto e mencionada direta ou indiretamente ao longo do mesmo. $\mathrm{O}$ acaso é catalisador das experiências do vagabundo e, consequentemente, também é fator de desestabilização do lugar-comum.

"Pagou caro, porque o que era conhecimento era morte também, e porque para se conhecer precisou de um outro, e precisou de confissão e a confissão e o outro deixaram-no pior ainda" (Rawet, 2004, p. 213). Conhecimento era morte porque exigia a intensa "descida ao fundo de si mesmo" (idem, p. 212), abaixo da superfície de tranquilidade a qual a maioria volta, iludindo-se:

Cumpria o destino que todos cumprem, e que a só uns poucos é evitado, esses que nunca duvidam de um único gesto ou palavra, que têm a rara felicidade de um desconhecimento absoluto. Os outros, os que ousam se conhecer realmente, adquirem o hábito do terror proporcional à intensidade da descida em si mesmo. Alguns ainda se iludem. Recebem como explicação um farrapo de ideia e uma distorção que permite uma volta à tona da tranquilidade (idem, pp. 212-213).

O movimento de descida e subida à superfície da indiferença e do ódio incorporado - polos de passividade - perpassa o conto.

A descrição minuciosa e direcionada do narrador cria uma cortina de fumaça que torna opacos os gestos do vagabundo e faz crer num devaneio intenso com gestos muito menos intensos. A artimanha, utilizada num trecho que dá pistas ao leitor sobre as motivações do vagabundo, acaba por reforçar a estrutura de ambiguidades do conto. Essas pistas guiarão o leitor por todo o texto. O que parece primário - "a repetição mecânica de um gesto tão antigo" (Rawet, 2004, p. 214) - é, na verdade, o menos importante, embora inevitável: "E foge às sensações físicas que daí resultam, foge porque são as que menos

\footnotetext{
${ }^{88}$ Cf. Anexo 2.
} 
interessam", provoca a si mesmo o vagabundo: "Vamos, nega isso também, nega-te esse direito de afirmar aquilo que na verdade ninguém pode te contestar, a não ser com a suficiência e o sorriso de uma polidez fictícia". A quietude decorrente do gesto é o que mais interessa, e a respiração torna-se "regular e tranquilizante sem que tivesse necessidade de torná-la consciente": "Com um tremor de corpo findou a vibração e uma quietude invadiulhe os membros e a cabeça. Tentou ainda ordenar a respiração, mas não era mais necessário; tornara-se regular e tranquilizante sem que tivesse necessidade de torná-la consciente" (idem, loc. cit.).

O primeiro impacto do conto é provocado por um trecho que por si só trabalha camadas de sentido, dessa vez não conflituosas, mas significativas de um texto que lida com a instabilidade dos sentidos. O trecho começa com um movimento de respiração "quase ritmado" (idem, p. 213) e termina com “a harmonia de uma explosão de dor” (idem, p. 214), num longo trecho de agitação física e subjetiva: uma cena de masturbação em que sonhos, lembranças, rejeição e desejo incontíveis, revelados numa confissão, são vivenciados. O desejo sexual é metonímia para o Desejo, que move a errância e comporta paradoxos.

A partir desse ponto, o vagabundo começa sua errância pela cidade, depois de terse registrado num hotel ${ }^{89}$. A errância do personagem pode ser vista como um almejado e quixotesco retorno utópico à origem da palavra: o espanto diante do mundo:

Anda, recolhe, recolhe tudo, recolhe esse esboço de canção que vem de um mundo que não conheceste, trauteia a cantiga que nunca ouviste, e que um outro dentro de ti cantou algumas existências antes de ti. Espanta-te com o reconhecimento das coisas primitivas que em ti ainda estão em ebulição, à flor da pele (Rawety, 2004, p. 214).

O caráter utópico desse espanto não o desqualifica como improdutivo; antes, dá a certeza de existir enquanto busca infindável e absurda, cheia de tropeços e recomeços.

\footnotetext{
${ }^{89}$ Significativamente, o atendente do hotel tinha "tiques efeminados". Isso sugere a possibilidade de envolvimento com o vagabundo. Mas isso não se dá: “O mulato [o atendente] observou-o mas sem encará-lo" (idem, p. 121). Sua homossexualidade insinua-se, apenas. Via no vagabundo apenas mais um cliente do hotel, com quem negociava um relógio, e por isso não houve sequer abertura para algum tipo de diálogo, não necessariamente sexual. $\mathrm{O}$ encontro com o atendente abre uma série de encontros "funcionais" por parte do Outro (i. e., provocados por alguma intenção definida e objetiva) em que se vislumbra a possibilidade de diálogo.
} 
Confere traços individuais ao Desejo. O vagabundo é um homem ao mesmo tempo comum e único, e se firma jogando com essas duas condições instáveis. Ele é comum porque é mais um daqueles "que passam", mas é singular porque reage ao mundo de maneira ativa, apropriando-se de seu espaço, e não sendo apropriado por ele, por meio do senso comum. Diferencia-se dos outros, a "maioria", porque percebe a inversão entre principal e secundário, na vida. Com isso, isola-se ainda mais do sujeito comum, que continuaria iludindo-se com aquela inversão. É um amaldiçoado ${ }^{90}$, pois "só encontrou um vislumbre daquilo que procurava entre os que ignoravam quase tudo e os que viviam à margem de uma estupidez estratificada em regra de comportamento [entendida aqui como convenções sociais]" (idem, p. 213, grifos meus). Os que estão no centro, na verdade estão à margem, e vice-versa. Essas inversões são centrais no conto.

As inversões podem ser entendidas da seguinte forma: os ignorantes de si mesmos são, portanto, aqueles que vivem de acordo com as regras sociais de comportamento; vivem segundo as convenções sociais (a superfície, rompida pelos que vivem à margem) e recebem "como explicação um farrapo de idéia e uma distorção que permite uma volta à tona da tranqüilidade" (idem, pp. 212-3, grifo meu). Os que vivem à margem - e que cumprem o destino que quase todos cumprem (idem, p. 212) - são os que conseguem ir ao fundo de si mesmos, e os poucos que têm a felicidade de não duvidar "de um único gesto ou palavra" (idem, p. 212) são os que voltam à tona, à superfície, segundo a imagem criada pelo conto. Os poucos que voltam à tona também são os indiferentes. A categoria dos que voltam à tona comporta dois extremos que se tocam, aparentemente muito semelhantes e contíguos entre si: os conformados e os indiferentes.

De acordo com a lógica do vagabundo, os que vivem respaldados nas convenções sociais contentam-se com "um farrapo de ideia e uma distorção" que lhe dão a ilusória e falsa essência de si mesmos: sua pretensa humanidade. Paradoxalmente, os que vivem à margem buscam pela verdadeira (correta, como ideal) essência de si mesmos - o que os faz submergir em si mesmos, ou, em outras palavras, afoga-os em si mesmos. São a maioria.

O gesto de ir a fundo não é, como se supõe, aventura de uns poucos, mas da maioria. Ir a fundo ou voltar à tona não são metáforas para determinismos sociais, possivelmente indicados pelo uso de termos gastos como "margem" e "sociedade", assim como a metáfora morta do "mergulhar em si mesmo". Uma conclusão possível se coloca: segundo as divisões do vagabundo, a maioria da sociedade vive à margem "da estupidez

\footnotetext{
${ }^{90}$ Solitário, mas não incomum. Desejo e errância andam lado a lado.
} 
estratificada em regras de comportamento" (Rawet, 2004, p. 213) - sem o perceber, justamente porque toma o aparente (ilusório) pelo essencial. A maioria deixa-se afundar no universo ilusório que tomam equivocadamente como sua própria essência - sua própria humanidade.

O essencial é vivenciado na superfície, mas não se vive sem as profundidades de si. Mas que superfície é essa, na visão do vagabundo?

Rawet questiona o lugar-comum, em "Crônicas...", valendo-se das mesmas regras pelas quais foram criados: a naturalização da linguagem, passando pela naturalização/cristalização da relação entre a palavra e seu referente (significante e significado), ao longo dos tempos. Naturalização essa que se fundamenta na lógica regida pelo conceito de essência e outros decorrentes deste: ideal, alteridade etc. Diante dessa realidade, a única chance de sobrevivência humanamente aceitável é, paradoxalmente, viver indiferente na superfície, correndo-se o risco de auto-anulação: "Se for preciso nega-te uma vez mais ainda, talvez a tua afirmação seja esse destino de constante negação. Aceita os paradoxos" (idem, p. 216, grifo meu). Resistir à possibilidade de auto-anulação é o destino do vagabundo, movido pelos opostos indiferença/ódio.

A ambiguidade desdobra-se ainda mais: "O que era tido como aparente, secundário, era o mais importante" (idem, p. 213). O par de opostos secundário/principal (ou: aparente/essencial) pode ser entendido da seguinte forma: "O que era tido como aparente" refere-se ao que era visto como lugar-comum (no sentido de senso comum). Por sua vez, o que era tido como "chão" (idem, loc. cit.) era, na verdade, o mais importante: inversamente, o que era tido como profundo, era na verdade o mais chão. Os lugares-comuns relacionados ao que é profundo e ao que é chão corresponderiam, portanto, à verdade - se invertidos seus lugares, isto é, se o que é senso comum chamar de "chão" for tomado como profundo, e vice-versa. Mas a simples inversão não mudaria nada. Seria preciso que o paradigma fosse outro: a superfície, e não as alturas (como em "Sôbolos...") ou profundidades, é por onde se desloca o andarilho - mas não os outros, que se afogam em lugares-comuns ${ }^{91}$.

A primeira premissa decorrente de toda essa lógica é que a margem é muito maior do que se pensa, e mais abrangente que o centro, expandido pelas linhas de força que o questionamento do lugar-comum projeta. Valores como "abjeção, a covardia, o

\footnotetext{
${ }^{91}$ Os outros, enquanto permanecerem nessa condição, não terão rosto. O vagabundo não é superior, pois seus paradigmas não são comuns (ou seja, a questão não se coloca nos termos inferior/superior); é simplesmente um desajustado heroico: um anti-heroi.
} 
ressentimento, o despeito são armas, válidas, porque humanas" (Rawet, 2004, p. 213), e o que antes parecia "covardia e abjeção" era, na verdade, sua coragem, manifestação do "extremo de coragem e pureza" humanas:

Pagou caro a sua coragem (só muito depois verificou que o que lhe parecia covardia e abjeção era o extremo de coragem e pureza). E atuava por ressentimento, e nunca por rebeldia pura. Mas deixara de acreditar em anjos humanos, principiava a se interessar pelos celestes. E como humano verificou que a abjeção, a covardia o ressentimento, o despeito, também são armas, porque humanas. Pagou caro, porque o que era conhecimento era morte também, e porque para se conhecer precisou de um outro, e precisou de confissão e a confissão e o outro deixaram-no pior ainda (idem, loc. cit.).

Indo mais a fundo, tem-se um contínuo que vai e volta da macro à microdimensão. A errância parte do caminhar, que por sua vez é uma sucessão de passos, obviamente. O momento extremamente fugaz em que põe um dos pés num terreno que, apenas naquele exato momento, é conquistado pelo vagabundo, até que o outro pé avance e o "pé-conquistador" se desloque para a vanguarda, para que a caminhada continue, e a vanguarda e a retaguarda se revezem em cada pé, de acordo com sua posição num dado momento da caminhada. O mesmo ocorre, guardadas as proporções, nas relações com fatos e pessoas, em "Crônica de um vagabundo": "Até mesmo aquele instante ali, tremendamente insuportável, seria apenas um incidente de mínima importância, logo ultrapassado por outro, até o dia de sua morte" (idem, loc. cit.).

A imagem do caminhar como conquista paulatina logo abandonada por necessidade da própria dinâmica do caminhar é constante, sob as mais variadas formas que o lugarcomum oferece, nos contos de Rawet, e nesse em particular. Seus desdobramentos como metáforas são sugeridos explicitamente pelo autor:

A sola cobria calçadas e ruas e em cada passada havia uma aproximação de território e ao mesmo tempo um abandono do anterior, território seu, absolutamente seu no instante em que o cobria com o sapato, mas também de todos os que antes ou depois dele passassem pelo mesmo rastro (Rawet, 2004, p. 216). 
A referência à memória coletiva é clara. A errância dos andarilhos implica, metaforicamente, na construção da consciência individual sobre algo (um fato ou um objeto) que tem de ser necessariamente desconstruído para que os conceitos que se formam a partir do confronto entre sujeito e objeto não se mantenham presos no lugar-comum, como sólidas convenções sociais, hábitos vazios de sentido, ou como o senso comum paralisante. Esse movimento localiza-se exatamente no instante entre um passo e outro, durante o qual a possibilidade de desequilíbrio é grande, a depender da superfície. A errância, que é mais do que apenas andar a esmo, é metáfora para a linguagem como material estruturador da realidade, sendo o caminho traçado ao final o texto a ser interpretado. A solidão do vagabundo mostra, então, sua face corajosa na necessidade vital de arriscar(-se) errando (isto é, "deixando de acertar" e vagando sem rumo), força subjetiva desagregadora, centrípeta, cujo centro é o "Eu" axial", bem como a linguagem na qual se constroi. Perder-se: errar, delirar - sonhar, esbatendo-se contra os limites da linguagem ${ }^{93}$.

Cada passo é a apropriação momentânea e extremamente fugaz de um lugar. Numa dimensão maior, a caminhada é uma sequência de apropriações fugazes, que se fazem e desfazem continuamente. A caminhada tem rumo incerto, mas os caminhos, assim como os encontros-confrontos concomitantes, são negociáveis diante dos fatos, personagens e objetos com os quais o andarilho se depara ao longo de seu percurso. O trajeto feito, ao final do conto, não importa: o que importa é o modo como foi feito; o percurso, e não o retorno a um lugar próprio familiar - que não existe ${ }^{94}$. Mesmo assim, continua-se errando.

\footnotetext{
${ }^{92}$ Ou seja, o andarilho como unidade minimamente estável: seu corpo como eixo do conto. Não seria apropriado falar em subjetividade centrada e unificada quanto ao andarilho, que atravessa "uma existência de transformações" (Reis, 2009, p. 77). Entretanto, o "Eu” descentrado e fragmentado é o eixo móvel do conto.

${ }^{93} \mathrm{O}$ título de um dos contos de Que os mortos enterrem seus mortos (1981) indica a transposição desse limite numa alalia (“gr. alalía,as 'má linguagem"; "perda total ou parcial da capacidade de falar”): “BRRKZNG: pronúncia - bah!”. A pontuação (dois-pontos, travessão, ponto de interrogação) e a indicação da pronúncia permitem a mínima legibilidade do título, mantendo-o atrelado à linguagem mesmo que seja “má linguagem”. Essa tênue ligação entre dizível e indizível faz lembrar uma glossolalia, linguagem "nadificada", ultrapassada. Fonte: Dic. Eletrônico Houaiss da língua portuguesa.

${ }^{94}$ Nos contos aqui trabalhados, principalmente "Crônica..." e "Sôbolos..." em menor grau, a pergunta pelo resultado ou consequência das errâncias dos personagens não é pertinente, pois pressupõe um objetivo claramente delineado, quando apenas a indefinição é claramente delineada. As errâncias são, por natureza, indeterminadas, não indicando planos ou caminhos exatos, no máximo intenções (que também
} 
O impulso ao movimento tem como resultado final uma configuração espaçotemporal imprevisível no início da errância. Pode-se então falar em utopismo, isto é, não um projeto coletivo claro, como as utopias clássicas, mas única e indefinida, movida apenas pelo Desejo (a "necessidade de cumprir seu destino" de que fala o andarilho de "Crônica..."; utopismo anárquico que deixa pistas mas recusa certezas - deixa rastros mas não indica caminhos)? Cada andarilho sinaliza um utopismo, e todos personificam, no âmbito de cada conto, o utopismo em si, isto é, disposições individuais projetadas no tempo e no espaço.

[O vagabundo] Sonhava o delírio. E vivia o sonho. Acordou com o quarto em penumbra e algumas fitas de luz do canto superior da parede contígua à janela. Nenhum espanto, nenhum regresso, nenhuma transição de um campo vago para os limites definidos de um quarto de hotel. Nos últimos tempos também essa necessidade desaparecera, pois os quartos de hotel passaram a integrar essa zona definida de uma vida irreal, varada tão brutalmente pelo concreto, pelo fato, pelo objeto, que atingira a consistência do sonho (Rawet, 2004, p. 214, grifos meus).

Entendendo-se o delírio como projeções do sonho na vigília ${ }^{95}$, o sonho seria o estado mais próximo dessa configuração espaço-temporal em que palavra e ação se equivaleriam, se o considerarmos como retorno impossível ao hipotético estímulo inicial, pré-verbal, que move o vagabundo - lá onde, segundo Türcke (2010), a cultura ${ }^{96}$ surge como perversão da natureza. Lugar espraiado na superfície, que não mira um horizonte

não são claras a princípio). As trajetórias, se fossem possíveis de serem traçadas, corresponderiam a momentos que se unem tão-somente pelo movimento dos personagens, que são os eixos imaginários dos contos (ou, dito de outra maneira, as personificações da errância). Cada um desses momentos são subnúcleos do conto (cf. Anexo 2): pedaços de um todo (a trajetória) que só poderia ser reconstituída por destroços desse mesmo caminhar. (cf. Anexo 1, Figura 1).

${ }^{95}$ Que, por sua vez, confunde-se com o sonho. Delírio significa "sair da lira”, do sulco escavado pelo arado, ou seja, dedicar-se a ocupações inférteis que não a agricultura. Lançar fora a semente: “Delirar vem do latim delirare, que na Roma Antiga significava: 'Afastar-se do sulco (lira) do arado. A riqueza provinha da agricultura simbolizada pelo sulco aberto pelo arado e onde se lançavam as sementes. Sinal de sensatez era dedicar-se à agricultura, donde, insensatez seria afastar-se do trabalho agrícola, da lira", (Silveira Bueno apud Lima, Três esquizos literários, p. 17). O sonho é feito de associações delirantes. O pensamento poético, diz Lévinnas, "pensa sem saber o que pensa, pensa como se sonha” (1997, p. 54).

${ }^{96}$ Solo no qual nasce e se desenvolve o lugar-comum. 
inalcançável, mas o aqui-e-agora eternamente mutável e inapreensível em sua totalidade. Superfície tecida pela linguagem fugidia e ineficaz. É a reversão sonhada de todo o processo cultural que a linguagem compartilhada representa, "ponto concreto de nosso contato entre o objeto e os nossos sonhos" (Rawet, 2004, 259) ${ }^{97}$. Não é síntese de ambos, mas local ideal e neutro (nem um nem outro), como um quarto de hotel: "zona indefinida de uma vida irreal, varada tão brutalmente pelo concreto, pelo fato, pelo objeto, que atingira a consistência do sonho. E pesadelo dentro do sonho" (idem, p. 215).

Assim, a loucura intromete-se "no seu universo desordenado" isto é, não faz parte dele; o "que era tido como aparente, secundário, era o mais importante" (idem, p. 213); principalmente, "as coisas primitivas" são resgatadas: "Espanta-te com teu comportamento de homem das cavernas, espanta-te com o reconhecimento das coisas primitivas que em ti estão em ebulição, à flor da pele. Devora um animal e alimenta-te dele, cultua os mortos que ainda estão vivos dentro de ti e manda às favas os que veem nisso sutilezas evidentes, porque não são tão evidentes" (idem, p. 214). Devorar, um ato primitivo, antecede o alimentar-se, isto é, nutrir-se de algo. O uso posposto de "alimentar-se", acompanhado por "Devora", torna-se quase uma metáfora. Suas conotações estendem-se por toda a frase, que é parte de uma provocação aos leitores pelo vagabundo: Devora um animal e alimenta-te dos mortos "que ainda estão vivos dentro de ti" (idem, loc. cit., grifo meu); devora-te a ti mesmo, para alimentar-te dos mortos que ainda vivem etc. As variações são inúmeras, ainda que delimitadas pelo contexto.

A inversão de valores e de pontos de vista mostra-se um movimento necessário em direção ao apelo do Outro. Ainda que isso não resulte em diálogo, tematiza-se a alteridade: "Rawet's attention to the perspective of the other shows how the consciousness of being other is central to a discourse that uses alterity to elicit thoughts about the side that is not another. In other words, Rawet's work is dialogical" (Vieira, 1995, p. 79).

A indiferença pela convenção (sinalizada como superfície), sua não-observância, leva à subversão da mesma. "Tudo é indiferente, portanto tudo tem o mesmo valor para ser observado" (Flusser, 2011e, p. 35). O observador indiferente paira sobre os valores daquilo de que se distancia, o que requer esforço. Mas como esse pairar é resultado de um esforço de auto-superação, é natural que caia e volte à superfície, onde volta a viver tendo, no entanto, de assimilar sua experiência de abstração (distanciamento).

\footnotetext{
${ }^{97}$ Esse espaço - idealizado - determinaria o grau de "hominidade" de um homem (p. 260). É fórmula usada pelo personagem Jano, de “O terreno de uma polegada quadrada”, no livro de mesmo nome (1969).
} 
Indiferença pode significar esquivar-se da responsabilidade para com o outro, própria do ser humano (Lévinas apud Kirshcbaum, 2011). Mas o olhar indiferente, diz Flusser, é aquele que não opõe resistências, e portanto não é crítico, no sentido de que não é “farejo desconfiado" (Flusser, 2011d, p. 109). Cada situação vivida pelo vagabundo é de total entrega aos impulsos despertados e às reações exigidas. O olhar crítico, lúcido, existe, mas é posterior ao primeiro olhar. Pode-se dizer que o primeiro olhar pretende-se puro (lúcido e distanciado) na medida do possível, uma vez que a necessidade de caminhar (que move o vagabundo) é continuamente alimentada pelos estímulos concretos: o cão que passa, o nordestino que lhe pede ajuda etc. Esses estímulos são o que chamei aqui de núcleos (e seus desdobramentos, os subnúcleos ${ }^{98}$ ) do conto "Crônicas de um vagabundo". Deslocandose entre esses núcleos e movido pelo ódio e pela indiferença, o vagabundo deixa-se levar por forças contrárias: a indiferença leva ao distanciamento crítico, enquanto o ódio atrai para o objeto odiado, do qual se aproxima. Dinâmica de paradoxos que sustenta um texto peculiar que procura evitar "pontos cegos culturais" ("cultural blind spots") e assim sobreviver psiquicamente, em sua diferença, no meio potencialmente hostil: "By emphasizing that the other is visible only through socialization and an 'I' perspective, Levinas underscores the need for vision, optics, and perception to avoid cultural blind spots" (Vieira, 1995, pp. 17$18)$.

Assim, Vieira insinua que haja estratégias textuais que tratem da alteridade e, ao mesmo tempo, lidem com a hostilidade surgida com o atrito entre o "eu" e o "outro". Como projeto literário de Rawet, segundo palavras do próprio autor em entrevista a Danilo Gomes em 1977 (dez anos após a publicação de "Crônica...”), essas estratégias visam à traição de "valores antigos para chegar a valores novos" (Santos, 2008, p. 328) - que fatalmente se tornarão valores ultrapassados. Encontra-se essa lógica da instabilidade e da indefinição, meticulosamente construída como (e sempre como) ficção, no personagem vagabundo que dá nome ao conto.

"Crônica de um vagabundo, "Kelevim" e "Sôbolos rios que vão" são errâncias a partir da própria linguagem, em seu próprio espaço-tempo único, peculiar à ficção (e ainda mais à metaescrita). Buscam-se indiretamente os fundamentos da linguagem, com a qual a realidade é construída passo a passo. Mas não se espera que aquela cumpra plenamente sua função desejável e impossível: expressar plenamente a realidade, isto é, fazer coincidir palavra e ação. Inevitável surgirem perguntas, jogos de palavras e ambiguidades nesse

\footnotetext{
${ }^{98}$ Cf. Anexo 2.
} 
campo de desejos que parecem não realizáveis, movido por ódio e indiferença, na busca pelo auto-conhecimento e pela expressão plena ${ }^{99}$. O rumo dessa errância primariamente física, mas movida a ódio e indiferença, é subjetivo e determinado como uma missão: cumprir seu destino. "Cumpria o destino que quase todos cumprem, e que só a uns poucos é evitado, esses que nunca duvidam de um único gesto ou palavra, que têm a rara felicidade de um desconhecimento absoluto" (Rawet, 2004, p. 212, grifos meus). O destino não é realizado como Desejo, mas é vislumbrado em momentos de lucidez gozosa? Ou a felicidade de que se fala é a da estultice ${ }^{100}$, e exclui a lucidez?

Em "Crônica de um vagabundo", as reflexões que guiarão o leitor em sua jornada são apresentadas nas quatro páginas iniciais desse extenso conto. Segundo Hohfeldt (1988), a trama dos contos de Rawet é "um plot [enredo] mínimo [...], pilares de cimento armado, sobre os quais se coloca o restante do material, que é, no entanto, o que mais interessa ao escritor - ao leitor". Como é comum nos contos de Rawet, a trama do conto ergue-se sobre pilares maciços que são facilmente discerníveis, mas cuja composição (os pressupostos, as inquietações e os sentimentos que movem o personagem) não é percebida sem que o leitor faça sua a errância do personagem. Paradoxalmente, esses pilares tornam-se frágeis à medida que a errância é traçada, uma vez que sustentam uma estrutura composta pelo mesmo material de que são feitos os lugares-comuns. Entretanto, o resultado não é um processo de auto-destruição, mas de lucidez - pelo personagem.

Mas nada se torna harmônico, muito menos estável. A consciência continua debatendo-se contra os limites da linguagem. Depois das aventuras na cidade, o vagabundo reflete, estirado numa cama de hotel, ruminando possibilidades inconclusivas:

O que fazer com sentimentos não tão dobráveis e que alguma conveniência algum dia condenou? Dobrar-se, dobrar-se sempre? Mas em caso contrário, fazer o quê? Aceitar hipóteses? Bitolar-se em uma direção que levaria à própria condenação, e ao absurdo de um preceito que todo o seu corpo negava, em vibração, em asco, em repulsa, em atração? (Rawet, 2004, p. 242).

\footnotetext{
${ }^{99}$ Entendo que essa busca tem uma meta, a expressão plena, como horizonte que se desloca à medida que se caminha - e que nunca é alcançada, o que a confunde com o Desejo.

${ }^{100}$ A estultice é uma das faces da loucura em Elogio da loucura, de Erasmo de Roterdã. Vale lembrar que a obra é dirigida a Thomas More, autor de Utopia.
} 
Posteriormente dirige-se então à rodoviária, local onde o conto termina e começa.

A errância do personagem principal apoia-se em dois aspectos, que sustentam a estrutura maciça do conto: as oposições complementares margem/centro, e principal/secundário $^{101}$. Desse material de oposições, composto por lugares-comuns, é feita a sustentação ficcional do conto, ou seja, seu enredo. Sem a participação do leitor, a estrutura do texto desabaria, pois perderia os pontos de contato entre as peças das quais é formado, uma vez que o material básico com que é feita é continuamente questionado: no entanto, o equilíbrio do conto é mantido. Nesse sentido, pode-se dizer que se exige do leitor a reflexão crítica sobre os lugares-comuns que se apresentam no texto, tanto ao longo da leitura quanto ao seu final, retroativamente. Não se trata, entretanto, de uma leitura forçosamente truncada, porque hermética, mas exigente.

A leitura ativa e atenta garante que o conto não exploda sob a pressão interna de suas próprias tensões, perdendo-se em raciocínios complexos e disparatados que lançariam o leitor para fora do texto, ou limitando-se à superfície (narrativa) do mesmo ${ }^{102}$.

A inversão indicada em "que era tido como aparente, secundário, era o mais importante" é um dado explícito do conto. O vagabundo procura verbalizar sua perplexidade num mundo de valores invertidos. Isso se dá no conto por meio de estratégia textual construída sobre a plurivocidade das palavras, engessadas em lugares-comuns.

Türcke (2010) propõe que a linguagem, e com ela o nome, estenda-se a toda a natureza. Todo nome surgiu do nome sagrado, que procurava abarcar a experiência primordial diante do desconhecido, incontrolável e assustador - experiência essa que deu origem à linguagem. Assim, toda palavra (nome) carrega consigo um "sopro mágicoutópico" que a remete a seu passado sagrado, o qual, por sua vez, torna-se o substrato da

\footnotetext{
${ }^{101}$ Denomino-as "oposições" porque denotam movimentos contrários entre si, ou seja, do centro à margem (e vice-versa); da essência à aparência (e vice-versa). Do contrário seriam meros pares complementares. As oposições em "Sôbolos...", no entanto, não são complementares. Pode haver processos diferentes nesses dois contos cujos personagens principais são andarilhos.

${ }^{102}$ A errância do personagem, feita de encontros ao acaso, cria espaços semelhantes às grutas dos
} Merzbauten de Kurt Schwitters (Fig. 2): "His development and interests defy categorisation; his work was devoted to his very individual concept, "Merz", which negates borders between types of art, between the deep and meaningful and the utterly banal, between art and life. 'Merz establishes relationships, ideally, between all things in this world." Fonte: http://www.sprengel-museum.com/the_kurt_schwitters_archive . Acesso em: 06/03/2012. 
linguagem: “[...] o nome é infectado teologicamente. Enquanto ainda expressamos nomes, não nos libertamos da utopia" justamente porque o "nome não consegue evitar o seu abuso, mas nenhum abuso consegue tirar o sopro mágico-utópico do nome" (Türcke, 2012, p. $253)^{103}$. Nomear implica conferir ao objeto uma essência, que forçosamente agrupa os objetos nomeados e estabelece ideais. Grupos e ideais são, portanto, conceitos construídos pela linguagem: "Natureza sem nome [tohuvabohu, caos] ainda não tem essência" (idem, p. 248). São regras sedimentadas que regeram (e regem) a nomeação das coisas do mundo, mas que deixam escapar o "sopro mágico-utópico" que as anima. Fundamentos aplicáveis ao vagabundo em sua errância.

Essas regras tácitas que conferem uma essência às coisas, humanas ou não, do qual a formação de lugares-comuns na linguagem é parte mais visível num texto ficcional, são utilizadas pelo autor, em seu questionamento desses mesmos lugares-comuns. O que se pretende encontrar quando se procura a essência das coisas, isto é, seu princípio norteador? O narrador dá uma pista, apelando para a metalinguagem: "Encaminhou-se para o ônibus com a consciência nítida de quem não vive a própria vida, de personagem defeituosa de um autor sem talento ou preguiçoso. Personagem de Deus, talvez” (Rawet, 2004, p. 243).

Não se pode falar em meta, uma vez que isso pressupõe um objetivo claro e ideal a se atingir ${ }^{104}$, e condicionaria toda a interpretação do conto, dando-lhe uma chave interpretativa (platônica). Não há chaves desse tipo em Rawet. Há núcleos que guiam a interpretação do conto, formados por centro e periferias (e dualidades periféricas), que se deslocam ao longo do texto e se interpenetram, criando zonas sobrepostas. Cabe lembrar que o poeta foi expulso da república platônica (uma utopia ela mesma) com consequências terríveis para a autonomia da literatura, como bem lembrou Kirschbaum $(2011 \text {, passim })^{105}$. Mas a margem é o terreno propício ao escritor não-engajado, que assim transita por onde passa o refugo do lugar-comum, matéria fértil à qual se lança o andarilho rawetiano. Mais uma inversão no conto: o refugo, e não o produto (o que resta, e não o que resulta) é primordial. A dualidade centro/periferia ilustra todas as inversões de sentidos de "Crônica..." ao manter as outras dualidades do texto, expressas muitas vezes por tautologias que lhes

\footnotetext{
${ }^{103}$ Waldman (2003, passim) aponta a busca pela expressão do nome impronunciável YHVH - e por isso eternamente glosado em textos sagrados ou profanos - da Bíblia hebraica como força motriz da busca pela linguagem plena, herdada pela literatura judaico-brasileira.

${ }^{104}$ A dificuldade em descrever a "busca" do andarilho já indica a ausência de um objetivo definido; autoconhecimento? Auto-expressão? Auto-apaziguamento? Ou seu extremo, a auto-anulação?

${ }^{105}$ Rawet obviamente estaria fora dessa democracia ideal platônica.
} 
tiram qualquer consistência: "Não delirava propriamente. Sonhava o delírio. E vivia o sonho" (Rawet, 2004, p. 214). Qual a fronteira entre sonho e delírio, vida e sonho, e outras tantas dualidades possíveis (até mesmo "sonho e sonho")? Não há.

Seguindo essa lógica de instabilidades dinâmicas, tem-se outra dualidade, dessa vez puramente linguística: “o faco e a garfa". Pilhéria do autor, perfeitamente funcional, como se vê. A solução indicada por "Personagem de Deus, talvez" é, na verdade, panaceia generalizante e escapista: o vagabundo é lançado ao Deus-dará, literalmente. Sob o olhar da auto-ironia, deduz-se que o personagem é gratuito, como todo personagem e - este é o cerne dessa solução aparentemente inocente e gratuita - toda vida humana. Ao invés de ser a busca pela pureza das coisas do mundo, encerradas numa natureza degradada, irremediavelmente perdida e ilusória em favor da essência escondida das coisas, o que sugeriria uma busca gnóstica, a errância do andarilho de "Crônica..." parte da descoberta da complexidade da subjetividade para, numa busca tortuosa e sem rumo, atingir os limites da linguagem e da consciência individual. O que, entretanto, não significa apaziguamento de si ou mesmo algum tipo de salvação, mas a constatação de uma eterna ${ }^{106}$ busca pessoal cujo horizonte nunca se alcança:

Deitou-se novamente impelido por uma torrente de ideias, número excessivo para não provocar uma violenta dor de cabeça. Qual delas aceitar, qual desenvolver, qual afastar? O que fazer com as coisas irreais duramente materializadas em dor? O que fazer com sentimentos não tão agradáveis e que alguma conveniência algum dia condenou? (Rawet, 2004, p. 242).

Ocorre-lhe então um conselho ao desconhecido escritor que o acolheu por algumas horas, e que escrevia um romance que pretendia "bem delineado, integrado no contexto histórico" (idem, p. 236): “Ao homem que está escrevendo a Revolução dos Canjicas gostaria de dizer o que lhe ocorre agora. O escritor é um cafetão de sua própria experiência, de seu próprio passado, de seus próprios sentimentos" (idem, p. 242). Com isso, respondia também ao que o tal autor do romance pretendia refutar com seu rigor histórico e factual. Dizia-lhe o romancista: "Há por aí uma ficção de fantasmas, de gente sem nome, de personagens sem passado, fantasmas mesmo, não entendo como se possa dar valor a coisas dessa natureza" (idem, p. 236).

\footnotetext{
${ }^{106}$ Eterna, mas circunscrita à vida.
} 
Cria-se aí um impasse, aos olhos do leitor: como escapar da impessoalidade falsamente rigorosa e não cair numa "ficção de fantasmas"? A resposta, como se viu, ocorre ao vagabundo algum tempo depois, quando volta ao hotel. Tem seu fundamento na figura do vagabundo como eixo do conto e nos ecos do lema do velho irreal que lhe aparece algumas vezes: "O mundo é um bordel e eu sou uma puta” (idem, p. 224).

Em síntese, o mundo é um bordel e todos são putas, e o escritor é seu próprio cafetão, segundo imagem usada pelo velho de "Crônica de um vagabundo". Qual a relação entre personagem e autor, segundo esses parâmetros? O personagem é a puta do autor, e o texto é o bordel da linguagem onde o autor prostitui seu personagem, dotando-o de "sua própria [do autor] experiência, de seu próprio passado, de seus próprios sentimentos" (idem, p. 242)", como um espelho cuja (falsa) imagem é construída e manipulada apenas pelo autor, mas visualizada pelo leitor. Sua contrapartida, uma inverossímil verdadeira imagem, não existe, uma vez que a biografia e a realidade factual não se sobrepõem à ficção, pois são registros diferentes. Não há hierarquia entre os registros:

A linguagem não está para sempre condenada a encobrir aquilo que é assustador. Assim como ela mesma surgiu de uma corrente inarticulada de sons, por sua vez pode tornar-se atuante de modo relevante, descobridor e diferenciador, e aos poucos executar a reorientação do encobrimento do susto para a descoberta da natureza (Türcke, 2010, p. 261).

A ficção, em “Crônica de um vagabundo", é redescobridora do potencial da palavra e valorizadora do registro literário da realidade.

Outro momento em que a linguagem aciona uma barafunda de sentidos que atordoa o leitor e exige sua atenção: "Embarca no delírio, alça voo, e vai ao fundo, para cima e para baixo, e voga ao sabor das confidências que já perderam o entretom de penumbra e confessionário, e grita, se for necessário" (Rawet, 2004, p. 214). Delírio, aqui remete ao "reconhecimento das coisas primitivas [...] ainda em ebulição, à flor da pele", e implica fugir “às sensações físicas que daí [do delírio] resultam "porque "são as que menos interessam". Dois opostos estão delineados, definindo o campo por onde esse voo se dá, "ao fundo, para cima e para baixo": o espaço público, exterior, objetivo (que, partindo do sujeito, define convencionalmente o que se chama realidade objetiva), onde se daria o grito; o espaço 
íntimo, interior, subjetivo, convencionalmente chamado realidade subjetiva ${ }^{107}$. As confidências se descaracterizaram ("já perderam o entretom de penumbra e confessionário"), mas continuam sendo confidências (i. e, revelações pessoais) que, antes restritas à reclusão num espaço que lhe é destinado convencionalmente (sinalizado por "confessionário"), agora deve alçar voo. "Aceita os paradoxos", ordena-se o vagabundo, "talvez a tua afirmação seja esse destino de constante negação" (idem, p. 216).

Aos sentidos suscitados pela memória do vagabundo, entrevê-se, ainda que indiretamente, pequenas mas profundas menções à memória coletiva. Além da breve última frase do conto ${ }^{108}$, não há outra referência implícita ao tema bíblico do exílio em "Crônica...". Mas a relação conflituosa com a memória coletiva, ao qual o tema do exílio se liga, está presente no conto, na imagem do culto aos mortos: "espanta-te com o teu comportamento de homem das cavernas, [...]. Devora um animal, e alimenta-te dele, cultua os mortos que ainda estão vivos dentro de ti e manda às favas os que veem nisso sutilezas evidentes, porque não são tão evidentes" (Rawet, 2004, p. 214).

No entanto, essas sutilezas (o comportamento e o culto aos mortos, ambos gestos de origem imemorável) são minimamente evidentes, e ainda são sutilezas: o fato de serem sutilezas é senso comum, mas não o fato de serem evidentes; estabelecer os matizes dessa evidência, que é fato secundário em relação às sutilezas (para o senso comum), torna-se o movimento de desconstrução necessário para que o fato dito secundário seja reconstruído.

O trecho "[...] a repetição mecânica de um gesto tão antigo que é simplesmente isso, um gesto antigo" mostra outro aspecto secundário que salta à frente, aos olhos do vagabundo: a repetição é o aspecto principal para o senso comum, o gesto antigo (o culto aos mortos) em si torna-se secundário diante desse costume (o da repetição) de origem remota: ou seja, torna-se lugar-comum. Cabe ao leitor desconstruí-lo com base nas reflexões do vagabundo, uma vez que o que é secundário ou principal é sugerido pelo personagem (indiferente) e costurado pelo leitor (interessado).

\footnotetext{
${ }^{107}$ A divisão feita aqui procura traduzir a lógica do texto, em que dualidades complementares são formadas. Textualmente, tem-se os seguintes pares: sonho/realidade (o principal), eu/outro, interno/externo (ao vagabundo). A realidade cliva-se em subjetiva e objetiva, confundindo sonho e realidades, cujas fronteiras são borradas, estruturando, ambos, um espaço utópico em que são um só espaço e realidade.

108 “[...] entrou no ônibus, ocupou o seu lugar, pensando no que poderia ser um fim provisório. Não de quem chega, ou de quem parte. Mas de alguém que apenas passa” (idem, p. 243).
} 
Esta é a força motriz do conto: a linguagem que se refere ao fato comum é revigorada como representação reelaborada desse fato, no confronto com o senso comum, no qual o que é representado é sufocado pela representação (i. e., a relação significadosignificante/referente-referencial encontra-se "cristalizada", para usar uma expressão cara a Rawet). Dessa forma, o simples gesto de avançar um pé depois do outro se torna metáfora para a construção de uma realidade a partir de fatos extremamente comuns, como o encontro casual e desprovido de sentido com um cão, que o impele ao movimento (caminhar) ${ }^{109}$ e relaciona-se, pelo traço comum da animalidade (instinto), ao ato de devorar (sinédoque de "alimentar" $)^{110}$ e ao culto aos mortos: o contínuo entre instinto e cultura é, dessa forma, delineado nesse simples encontro com um cão errante.

Saiu do cinema. À vista de um cão um impulso induziu-o a encetar uma caminhada que se realizava em si mesma, sem destino, não porque vagasse à toa, mas porque não havia destino. Todos os incidentes passaram a funcionar como evocadores de seu mundo animal, e como evocadores de um mundo próprio que não se coaduna com as palavras, nem com as sutilezas, mas com a ação bruta, encerrada em ganga e escória de hábitos e afetos (Rawet, 2004, p. 215).

A palavra toma dimensões textuais diferentes, numa linguagem que demonstra mais liberdade (ou: labilidade) de sentidos que a prosa comum, aproximando-se da poesia, conforme afirma Cortázar (2010, p. 234) sobre o conto breve ${ }^{111}$ : "A gênese do conto e do poema é, contudo, a mesma, nasce de um repentino estranhamento, de um deslocar-se que altera o regime 'normal' da consciência"112. A linguagem volta-se para a ação bruta no

\footnotetext{
${ }^{109} \mathrm{O}$ cão aparece duas vezes e desperta reflexões complexas no andarilho.

${ }^{110}$ Alimentar-se, obviamente, implica devorar, que aqui pode ser vista como uma forma mais agressiva e animalesca de "comer".

111 A afirmação é válida também para "Crônica de um vagabundo", um conto longo, ou "novela curta, experimental”, em palavras de Rawet (cf. Santos, p. 244). Vê-se que a forma do conto também foi atingida pelo experimentalismo, se cada subnúcleo do conto for considerado um "conto breve" nos termos de Cortázar mencionados aqui.

${ }^{112}$ A citação segue, justificando-se de uma forma que também caberia aos ensaios-crônicas-relatos de Rawet, como "Diário de um candango": "num tempo em que as etiquetas e os gêneros cedem a uma estrepitosa bancarrota, não é inútil insistir nesta afinidade que muitos acharão fantasiosa" (idem).
} 
conto, evitando que a mediação das palavras e das sutilezas livrem a ação de sua "ganga e escória de hábitos e afetos". Estes inevitavelmente permanecem, já que é a partir deles que se forma a percepção do vagabundo. Mas são lugares-comuns reelaborados textualmente: assim, o encontro sexual com a prostituta, por exemplo, que habitualmente é tomado como fonte de satisfação, desperta repugnância mútua e revela manifestações vazias de afeto.

Esse mecanismo textual de reelaboração desses "hábitos e afetos", lugares-comuns da convivência, vale-se de elipses que se revelam em alguns dos subnúcleos do conto ${ }^{113}$. No encontro com a prostituta, o andarilho deixa-se levar pela proposta tácita da relação sexual paga. O que decorre dessa disposição do personagem em se deixar levar por esse fato não é apenas o encontro sexual, mas o modo como os dois personagens lidam com a intimidade forçada, mas completamente comum e esperada entre uma prostituta e seu cliente:

Qualquer palavra que trocassem agora seria supérflua. Nele uma ponta de inquietação presente já no próprio sorriso instantâneo, mecânico, nela uma irritação maior por uma entrega além dos limites impostos pela sua condição. Tem-se a impressão de que às vezes esboça um movimento, um gesto que poderia trair uma intimidade ou um desejo de maior aproximação, talvez agradecimento, mas morde o lábio inferior e acende um cigarro (Rawet, 2004, p. 218).

Percebe-se uma série de gestos indecisos, movidos por impulsos que não se completam e que surgiram do encontro entre cliente e prostituta, que por sua vez remete ao ancestral instinto sexual ${ }^{114}$. O único gesto de aproximação que parece cumprir-se, e que encerra sentidos implícitos, é a troca de olhares com uma outra mulher que convalesce de um aborto desastrado. A aproximação dá-se por um gesto rápido ocorrido casualmente depois de uma série de sensações que conotam medo:

Um pouco de hesitação à entrada do edifício do apartamento, constrangimento pela presença de um terceiro no elevador, e alívio na saleta onde uma loura de olheiras imensas e voz grave cochila sobre um sofá enrolada em cobertores. [...]. Ele intercepta-lhe o olhar ao seguir para o

\footnotetext{
${ }^{113}$ Cf. Anexo 2.

${ }^{114}$ Ancestralidade representada pela menção ao "homem das cavernas", no conto.
} 
corredor, e aceita um sorriso de simpatia vindo da penumbra. Era preciso redescobrir tudo, redescobrir o valor de um gesto cujo significado se perdeu há muito tempo e que sempre esteve envolvido em intenções ambíguas (idem, p. 217, grifos meus).

Em meio a variações do medo, sentimentos confusos e oscilantes, e toda "ganga de afetos e hábitos" cristalizados, o sorriso voluntário e a troca de olhares quebram a superfície de todo o contexto. Após o serviço prestado e pago, sua "presença agora era mais ou menos indiferente, fora ao fim da negação, podia regressar [à superfície, mencionada no início do conto?] se houvesse no regresso algum acréscimo à sua capacidade de afirmação" (idem, loc. cit.). O que é premente, portanto, segundo sugere o vagabundo, é trazer esse aspecto tornado secundário pelo costume (o gesto do sorriso de simpatia e o culto aos mortos, no conto) de volta ao seu verdadeiro lugar de valor, estabelecido por sua própria antiguidade e universalidade: "redescobrir tudo, redescobrir o valor de um gesto cujo significado se perdeu há muito tempo". Porém, não o faz sem escorregar "nos paralelepípedos da ladeira" (idem, p. 219), nas reminiscências (que "não são bem reminiscências") e nas definições "exatas": um equilíbrio tenso perpassa o conto inteiro: "Atravessa a rua, contorna o bar, a agência de automóveis, quase escorrega nos paralelepípedos da ladeira que contorna o edifício da esquina, segue pela calçada em direção ao mar. [...] Caminha com a serenidade de quem cristalizou todas as angústias”. O que, contudo, não implica exatamente uma estabilidade, mas o equilíbrio mínimo para se manter em pé:

O inevitável fluxo da reminiscência de quem caminha, inevitável como o caminho, que pode ser qualquer um, mas que sempre indica uma direção, um sentido, um transitar de algum lugar para outro, ou de um tempo para outro. Na verdade, não são bem reminiscências, mas um estado permanente de lembrança que desaparece sob o impacto da ação, e que reflui ao mínimo descuido, ao mínimo repouso, à menos pausa. Não são bem reminiscências, mas acontecimentos ainda presentes e que não esgotaram sua energia em potencial, ainda atuantes, e incrivelmente futuros (Rawet, 2004, p. 219). 
Por falta de um termo exato, há necessidade da glosa acima e da permanência contrariada do nome mais próximo da experiência: "Apenas o desgosto de conceder-lhe exatamente essa condição de reminiscência, de tentar revesti-los de uma aura sentimental que se julga implícita em tudo que diga respeito a passado, se é que é passado" (idem, loc. cit.).

O “que não são bem reminiscências" diz respeito ao passado, "se é que é passado: Semelhantemente, o antigo costume do culto aos mortos difere do também antigo comportamento (instintivo) "de homem das cavernas" apenas por sua repetição: um gesto tão antigo é reiterado através dos tempos e tem na civilidade sua capa protetora e legitimadora - enquanto o mesmo não ocorre com o instinto (referido pelo "comportamento de homem das cavernas"), que é sufocado por essa mesma capa. O gesto do culto aos mortos tem seu paralelo na antiga canção nunca ouvida, mas que ainda vive, vinda "de um mundo que não conheceste”. Já o comportamento primitivo tem expressão em um grito descrito estranhamente em termos musicais: "alto, bem alto [...] ganhe talvez modulações antimelódicas, conservando porém a densidade, a espessura e a harmonia de uma explosão de dor" (Rawet, 2004, p. 214, grifos meus ${ }^{115}$ ).

O jogo de opostos é metafórico, mas o próprio caminhar em que se baseia também se prestaria a metáforas que confirmariam seu sentido (secundário ou principal, dependendo de onde se parte). Mais uma vez, a participação do leitor é exigida, e as oposições são esgarçadas, de modo que secundário e principal se confundem, mantendo seu nexo com a realidade da qual partiram: o culto aos mortos e seus desdobramentos metafóricos.

Assim como a caminhada palmilha caminhos já feitos anteriormente, o lugarcomum constroi-se como uma trilha de sentidos estabelecidos que, por ser refeita várias vezes, é tomada como caminho previamente traçado. Encontra-se, na síntese solidamente construída pelo lugar-comum (a percepção e sua ganga de "afetos e hábitos") e legitimada

\footnotetext{
115 A antimelodia harmônica sugerida pelo grito de dor pode ser interpretada como uma dissonância que obedeça à tonalidade da música da qual o grito faz parte. À música nunca ouvida contrapõe-se o grito dissonante, e é esse contraponto que legitima a tal música, e não sua mera repetição apática. O grito é dado pelo indivíduo, enquanto a música existe independente de sua vontade, enquanto normas com que se confronta durante a caminhada. $\mathrm{O}$ grito também se contrapõe à ordem necessária (pois o corpo só se constitui como tal se aceita a lei que o inscreve nos jogos simbólicos), manifesta na música melodiosa do ideal. O grito, sem palavras, assustaria mais do que numa música com palavras e gritos do que uma música feita apenas de gritos.
} 
por seu uso, o caminho para se retornar à relatividade de sentidos originária estancada pela formação do lugar-comum ${ }^{116}$.

Além de ser metáfora morta, o lugar-comum pode ser fonte de riqueza literária pelas possibilidades latentes encerradas pela casca da expressão vulgar tomada como significante - ou seja, mitificada, nos termos de Barthes (1993). Sobre isso, afirma Labarthe: "Il y a dans le lieu commum um pouvoir synthétique qui autorise l'accès à une valeur absolue du relatif, le dévoilement d'un sens latent enveloppé dans sa littéralite de locution vulgaire, comme garanti par la mémoire collective" (2000, pp. 137-138).

Assim, o lugar-comum pode ser tanto um clichê como as situações criadas pelo clichê: por exemplo, as convenções criadas pela linguagem comum (vulgar), as quais, por sua vez, engendram situações em que são postas à prova. Nesse sentido, a aversão pela prostituta, a hostilidade inicial pelo velho, a ingenuidade do golpe que dois homens tentam aplicar no vagabundo, entre outras situações imprevistas mas procuradas, são momentos em que o lugar-comum (enquanto convenção de expectativas) se revela e é posto à prova.

Um ideal pode ser depreendido das palavras de uma mulher encontrada pelo caminho, autora de um "Código da solidão" incompleto:

E sonhou. Se fosse possível eliminar a palavra, a mentada e a falada. Seríamos objetos, viveríamos num mundo apenas de acontecimentos, e todos estritamente necessários. Reduziríamos a nossa inteligência ao fazer, e ao raciocínio destituído de vocábulos, que estaria implicitamente ligado à ação (Rawet, 2004, p. 240).

São palavras parecidas com as do velho, mas leia-se "sonho" onde estiver "meditação" e a mensagem fica ainda mais parecida:

A última instância da meditação é uma torrente de palavras desconexas, uma descarga com a rigidez de uma lógica implacável que não permite entendimento algum, ligação alguma entre a primeira e a segunda palavra. Apenas a torrente, o fluxo de uma compreensão além da compreensão (idem, p. 224).

\footnotetext{
${ }^{116}$ Tomo como pressuposto o fato de que essa "ganga" é formada pelo afeto e pelo hábito, segundo o conto.
} 
As palavras (vocábulos, na fala da mulher) atrapalhariam a compreensão, porque tolheriam a ação. Resta desfazer-se das palavras, ou implodi-las, fazendo-as desabar com sua própria força represada pela linguagem cristalizada. O que restaria, senão a utópica identidade entre sonho e realidade? A possibilidade ou não de isso acontecer é pragmática: não é possível, mas não deixa de ser desejável, segundo o contexto. Ou seja, não deixa também de ser possível no final das contas, segundo a lógica de torções de sentido, no texto.

$\mathrm{O}$ vagabundo sonha com fatos acontecidos ainda naquele dia: o encontro com a mulher que observa a chama dos maçaricos na madrugada e que tem seu código da solidão. Seu sonho começa com uma lembrança quase literal do encontro com a observadora e termina com um trocadilho inexplicável (“O faco e a garfa”). Essa é também uma parte do percurso do vagabundo, quando as palavras da solitária observadora tornam-se suas, repetindo quase literalmente a fala da personagem, algumas páginas antes: "Deitou-se embriagado pelo calor que sucedeu ao despertar da água fria. E sonhou. Se fosse possível eliminar a palavra, a mentada e a falada" (idem, p. 240).

A observadora repudia o caráter puramente simbólico de sua admiração pelas chamas do maçarico. O fato em si é belo, diz, não precisa de causas e efeitos que o valorizem:

Esses homens que soldam trilhos à noite me atraem, e eu gosto de ver a chama dos maçaricos. Um idiota de um psicanalista já tentou me explicar que isso é simbólico, e não sei mais o quê. Tenho a impressão de que ele nunca viu um maçarico funcionando de madrugada (Rawet, 2004, p. 234).

Também no sonho, o quase-atropelamento de que fora vítima havia poucas horas torna-se o encontro com um homenzinho que repetia "queijo, queijo, queijo" e lhe pede que diga "a faca e o garfo". A cena seguinte, um dos subnúcleos do conto (cf, Anexo 2, item 20) ocorre durante um sonho. A citação é longa, porém necessária, e diz respeito ao trabalho com a linguagem:

É empurrado violentamente e fez um caminhão de feira frear bruscamente, causando a queda de dois tabuleiros e um cavalete. Voltou-se e não compreendeu as risadas de satisfação do homenzinho gordo e alourado. 
Batia com as mãos, dava pulinhos, e com um fiozinho de voz repetia queijo, queijo, queijo. Aproximou-se e a figurinha o deteve à [sic] distância de um braço estendido. E o fiozinho de voz ordenou. Diga: a faca e o garfo. Ele olhou sem compreender, mas tentou articular. Pronunciou: o faço e a garfa. A figurinha rechonchuda explodiu numa gargalhada cascateante, os bracinhos se agarraram à barriga e rodopiou sobre um pezinho delicado, apoio miraculoso que mais parecia ponta de pião. $\mathrm{O}$ faco e a garfa. $\mathrm{O}$ faco e a garfa. $\mathrm{O}$ faco e a garfa. Enquanto o pião rodopiava ele ia repetindo, repetindo, até que os lábios se imobilizaram num grunhido. Deu costas à figurinha rechonchuda e ficou de frente para a rua. Um caminhão de feira se aproximava. $\mathrm{O}$ bracinho ganhou energia e empurrou-o violentamente. Ouviu a freada e o estilhaço de madeira no asfalto. Acordou com o estardalhaço no corredor (idem, p. 214).

A repetição de palavras e situações (inclusive a repetição de "repetir"), se condensa na repetição do trocadilho "o faço e a garfa" até que, num giro que aumenta progressivamente, o trocadilho torna-se um grunhido, É claramente um trocadilho com a expressão "ter a faca e o queijo na mão", que, como é sabido, significa ter a oportunidade perfeita para se fazer algo. Rawet joga com uma expressão popular e o simbólico da Psicanálise ao referir-se à ação bruta e às palavras com que inevitavelmente se busca compreendê-la e expressá-la. O trocadilho lúdico exclui intenções ocultas e sérias que seriam vistas sob a óptica psicanalista, o que aproxima o vagabundo da mulher misteriosa que gostava de ver maçaricos à noite e não se fiava em explicações psicanalíticas.

O sonho do vagabundo pode ser interpretado pelo leitor por essas duas chaves: a ação não é simbólica, mesmo no sonho, e deve inevitavelmente lançar mão da palavra para ser expressa. O trocadilho com "garfo e "faca", repetidos pelo homenzinho incessantemente, é puramente lúdico e gratuito: deságua em gargalhada. A interpretação simbólica é posta de lado, na narrativa, e o sonho tem em si mesmo seu valor de realidade transformada - mas nem assim menos valorosa. O que se tem neste conto que começa com o batidíssimo "Era uma vez" é a valorização da elaboração ficcional em si, e não dos conceitos prontos de que 
pode se fazer de veículo ${ }^{117}$. O espaço entre a ação e o objeto deve ser inevitavelmente mediado pela palavra, e é irremediavelmente impreciso.

Inconsciente e consciente, sonho e realidade, são espaços da percepção que estão confundidos no conto - o que tem como função textual confundir seus contornos, restabelecendo essas dualidades complementares como polos de um contínuo ilocalizável porque metafórico. Por isso o sonho é vivido, e não sonhado: "E vivia o sonho". A errância não tem rumo, mas o "desejo reconhece o desejável em um mundo exótico" (Lévinnas, 1997, p. 36). Nos contos aqui analisados, o desejo sexual deixa entrever o Desejo de que fala

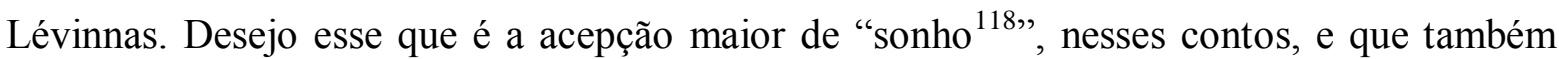
chamei aqui de utopismo.

Assim, o corpo de uma velha moribunda suja de fezes faz lembrar o de uma prostituta decadente, provocando uma gargalhada escandalosa e desavergonhada no vagabundo. O impulso de ceder ao apelo da prostituta e ao pedido de ajuda do nordestino que o aborda na rua e o leva até a velha é o mesmo, embora tenha causado um certo nojo com a prostituta, mas não com a velha. $\mathrm{O}$ nome para esse ato de consequiências diversas e origem comum não é uma virtude qualquer (como caridade), mas a necessidade cega de ceder aos impulsos, mesmo que causem náusea. As contradições que carrega consigo são sempre um fardo do qual não consegue se livrar, como a relação sexual com uma prostituta que lhe parece indiferente:

Já não era dono de si mesmo, estava entregue ao seu mundo de evocações e de hábitos nem sempre justificáveis. A miséria de um ato presente mesmo no instante de prazer, de um ato que lhe fora algumas vezes negado, e outras carregado de um acúmulo de contradições, uma carga que se desejaria eliminar não com o intuito de santidade, mas de um equilíbrio humano elementar (Rawet, 2004, p. 218, grifo meu).

Portanto, ceder a todo impulso seria a tentativa espontânea de se livrar, dobrando-se a qualquer necessidade legítima despertada em si ou no outro, da carga de contradições que

\footnotetext{
${ }^{117} \mathrm{O}$ autor dá a entender uma opção por uma literatura não-engajada, como expressão estética pessoal, compartilhável mas nunca esgotável.. Essa posição pode ser depreendida em outros contos, inclusive em "Sôbolos rios que vão".

${ }^{118}$ Esta palavra, polissêmica, é muito usada nos contos enfocados.
} 
o aflige - dinâmica existencial do personagem que se traduz no lema do velho errante: "O mundo é um bordel e eu sou uma puta" (idem, p. 224). Cada passo é a tomada inevitavelmente extrema e fugaz de um território que, a princípio, não é seu, porque já fora apropriado por outros que o trilharam antes ${ }^{119}$. Firmar o pé num território estranho em que se dá a relação com o mundo é, para o vagabundo, entregar-se ao medo de que o chão lhe seja tirado, ou não seja firme.

Esses são os desdobramentos de uma ampla metáfora morta reelaborada num texto de ficção: o mergulho em si mesmo. Paradoxalmente, mergulha-se em si mesmo para encontrar os valores da superfície do mundo. Pois esse mergulho é feito pela maioria das pessoas, e poucos voltam à superfície, reconhecendo a profundidade do que é chão, ao trocar os paradigmas para o que o senso comum chama de "profundo" e de "chão": "O que era tido como aparente, secundário, era o mais importante" (idem, p. 213).

Diante do que foi exposto neste esmiuçar de "Crônica de um vagabundo", vê-se que a troca dinâmica entre texto e leitor é fundamental na compreensão do conto. Nesse sentido, assim como para Cortázar (2011, p. 86), a "tendência metafórica é lugar-comum do homem”, para Certeau (1994, p. 50), o lugar-comum está presente numa simples conversa em que "o entrelaçamento das posições locutoras instaura um tecido oral sem proprietários individuais, as criações de uma comunicação que não pertence a ninguém”. É, portanto, espaço em comum, de todos e de ninguém: de uma comunidade de limites tão amplos que não se restringe a uma só comunidade, mas cuja multiplicidade torna-os tão estreitos que não se pode escapar de seus limites. Nesse jogo de espaços em comum, jogos verbais e simbólicos que tomam lugar em espaços igualmente verbais e simbólicos comuns e ao mesmo tempo estranhos, apropriados (mas nunca próprios) e inescapáveis, a leitura silenciosa do texto ficcional joga o leitor e o texto num espaço de trocas: "A fina película do escrito se torna um remover de camadas, um jogo de espaços. Um mundo diferente (o do leitor) se introduz no lugar do autor" (Certeau, 1994, p. 49, grifo meu). O autor, aqui, é considerado o primeiro leitor de seu texto; por extensão, e guardadas as proporções, o leitor é recriador do texto que lê nessa dinâmica de funções que gira em torno do texto literário. A leitura - e Certeau fala especificamente em obras literárias - é, necessariamente, ativa: negociadora de sentidos e significados, sopesando percepções e suspeitas que se confirmam

\footnotetext{
${ }^{119}$ Como uma picada aberta por outrem, que a cria definindo seu traçado segundo suas próprias necessidades.
} 
ou não, criando expectativas que se confirmam ou não, e outras táticas de leitura em que se apropria fugazmente (durante o tempo da leitura) do espaço do Outro, a saber, o texto literário. Os fundamentos desse espaço em comum a autor e leitor são guiados pelo personagem, centro e motivador único de todo o jogo de sentidos próprio do conto como obra literária.

Como táticas do fazer cotidiano, uma simples conversa põe em jogo os lugarescomuns. São não-lugares em que o "esfarelamento das estabilidades locais" tornam errantes as táticas dos fazeres individuais (no sentido proposto por Certeau, 1994), o que faz com que os indivíduos tenham de se arriscar em terrenos de fronteiras fluidas (ou seja, nãolocais) do senso comum, que podem-lhe ser estranhos e/ou familiares - assim como é seu interlocutor.

A mesma dinâmica tática, i e., de apropriação do lugar estabelecido (em disposição e em regras) pelo Outro, pode-se verificar no próprio texto ficcional como o confronto entre o andarilho de "Sôbolos..." ou o vagabundo de "Crônica..." com os estranhos encontrados nas variadas situações ao longo desses dois contos. Então, o encontro do vagabundo com a prostituta, com o homossexual e com a velha não são auto-entrega compassiva, embora a disposição para segui-los faz o leitor crer nessa disposição por parte do vagabundo, num primeiro momento de leitura; o momento em que o encontro com um cachorro o faz sentirse disposto a caminhar é apropriado e fixado no texto sob a forma de divagação filosófica. A apropriação efêmera do lugar do Outro, como tática de confronto com o estranho (daí o medo de que o personagem tanto fala), é astúcia, diz Certeau (1994, p. 100): A gargalhada incontida e escandalosa do vagabundo logo ao sair da casa da velha moribunda de quem cuidara não faz sentido no texto, se for relacionada apenas à aceitação inesperada do pagamento pela caridade feita:

O tipo estendeu-lhe uma nota de mil. Pensou em recusar mas um balanço rápido em suas economias, e um desejo de evitar maiores explicações impeliram-no a aceitar imediatamente. Na ruaainda pensava no tipo baixo e forte que certamente esperava uma recusa, uma conversa, um gole outra recusa, e que agora devia estar safado com esse tipo esquisito que nem capaz de uma caridade é (Rawet, 2004, p. 228). 
Um fio mais tênue do conto liga a velha à prostituta, por sinédoque - "pele esponjosa" e "pele acetinada", respectivamente, a pedir sutilmente que o leitor se valha de uma forma de astúcia, exigida pelo texto, que subverte o lugar-comum, despreza a inocência e outras formas de pureza de espírito convencionais ${ }^{120}$ : a malícia, diluída no conto. Ao aproximar a prostituta da velha moribunda, depois de ter conhecido ambos os corpos, só uma aproximação maliciosa explica a reação do vagabundo:

Pensou no corpo da velha, e pela primeira vez um esboço de ironia lhe sublinhou os gestos. Altos pensamentos. As neves de outrora. Toma aqui, rapaz, e um grande porre! O bêbedo não entendeu bem, aprumou-se junto à banca de jornais e ficou olhando à luz da lâmpada ob o toldo do jornaleiro a nota de mil. Ao compasso da mala, e do cigarro, constatou surpreso sua condição de profissional de outra profissão, de qualquer uma, de nenhuma. Uma gargalhada irrompeu do estômago e dobrou-se sobre a calçada sem parar (idem, loc. cit.).

A malícia e o Desejo revelam-se debaixo da caridade como valor cristalizado. Mais uma vez, tem-se um lugar-comum - a caridade da "alma caridosa do interior"121 - como ponto de apoio sobre o qual se constrói essa tensão harmônica e instável que também é o traço mais marcante nos contos rawetianos. Os andarilhos rawetianos partem em busca de conhecimento - de si, do Outro e do mundo: três aspectos de um mesmo real inapreensível diretamente. Desconstroi-se o lugar-comum para se desnudar a existência humana, grosso modo.

\footnotetext{
${ }^{120}$ Um suposto gesto de pureza convencional, cuja caracterização ficcional é claramente sarcástica, a doação de "um embrulho de dinheiro" a ser doado a um orfanato por uma "alma caridosa do interior", exige a astúcia do leitor assim como exigiu a astúcia do personagem, facilmente tomado como uma "alma caridosa" pela sua disposição em "ajudar o Outro", durante o conto.

${ }^{121}$ Caridade em seu sentido literal, sem conotação estritamente religiosa: atitude desinteressada, ("lat. carìtas,átis 'carestia, preço alto; amor; caridade". Fonte: Dic. Eletr. Houaiss, verbete caridade; "2 Benevolência, bondade, bom coração, compaixão". Fonte: Dic. Online Michaelis. Acesso em: 26/02/2013. Disponível
} em:http://michaelis.uol.com.br/moderno/portugues/index.php?lingua=portuguesportugues\&palavra=carid ade). 
"Crônica de um vagabundo" pode ser sintetizada muito rapidamente na seguinte paráfrase livre: $\mathrm{O}$ núcleo de toda vida humana é o fato (e a constatação óbvia, mas necessária) de que o homem existe transitivamente no mundo e o constrói à medida que transita nele (isto é, que o vive); e desconstroi sua herança simbólica (da qual os lugarescomuns são parte) para poder viver responder aos estímulos do meio e sanar suas necessidades, revolvendo as potencialidades estanques em valores, tradições e hábitos (ou seja, os lugares-comuns) da sociedade em que vive, e revitalizadas na forma do caos criativo e da inevitável angústia identitária decorrente da instabilidade inerente ao caminhar, manifesta em qualquer forma de relação interpessoal - conforme o conto descreve ${ }^{122}$.

Outras paráfrases são possíveis para o conto, tantas quanto são possíveis suas leituras e variados os leitores. A errância do vagabundo é como o paradoxo de Zenom: torna-se interminável à medida que se desloca no espaço, redefinindo o centro do deslocamento. Transita-se por um território comum; "espaço absoluto" sem concessões, mas que por um momento se torna propriedade de quem passa pelo "mesmo rastro" (Rawet, 2004, p. 216), como os costumes: eis a universalidade do vagabundo. "Meu universo é outro", diz ele: não é feito de palavras nem argumentos, mas de "ação pura". A ação pura do personagem traduz-se, no entanto, por palavras. Nessa tradução, a marca da ação pura é a instabilidade de sentidos presente no conto, sempre se deslocando.

A questão da alteridade perpassa esses contos, entrelaçando-se a dualidades. Ademais, a distância entre um sujeito e outro é sinalizada por elipses de subjetividade - algo muito marcante em contos reflexivos como esses, nos quais a subjetividade confunde-se com a objetividade, e o dito, com o não-dito. $\mathrm{O}$ andarilho procura distanciar-se da linguagem usual, paradoxalmente parte da mesma para reconstruir a própria realidade, sufocada e homogeneizada pelo lugar-comum.

\footnotetext{
${ }^{122}$ A mera descrição da fábula do conto - um sujeito vaga por uma cidade e passa por várias situações não daria conta dos sentidos textuais verificados nesta paráfrase livre. "A fábula de uma narrativa se situa no interior das possibilidades míticas da cultura”, diz Cortázar (2011, p. 194). O estilo do autor é que define o tratamento do tema e a fábula da narrativa: "sua [da fábula] escrita se situa no interior das possibilidades da língua" (idem). Deve-se lembrar que o escritor define suas escolhas diante das possibilidades da língua. Assim, a fábula de "Kelevim" - um homem caminha por uma cidade imaginada - não diz quase nada sobre o conto, e sim o modo (estilo) como isso acontece ou deixa de acontecer, nesse e nos outros contos trabalhados aqui.
} 


\section{O Judeu Errante}

On dit que as souffrance et as mort représentent le plus grand événement que le monde ait connu, le plus significatif. Oui, peut-être, cést possible. Mais combien on souffert sans que leur souffrance ait la moindre valeur? (Lagerkvist, La mort de Ahasvérus, citado por Rawet)

A epígrafe da qual também me valho, tirada do romance "A morte de Ahasverus" (1964), abre o conto "Crônica de um vagabundo" trazendo à tona o fantasma de uma figura ligada à errância - e, indiretamente, por extensão, ao exílio e ao desenraizamento. Sendo a errância o que move o vagabundo, e diante da polissemia própria à escrita de Rawet, mostra- 
se necessária uma visada curta, porém detida, sobre essa figura, Ahasverus, que se mantém à sombra do conto.

Ahasversus, como é sabido, é o nome do Judeu Errante que é personagem da obra e que está condenado a um exílio por tempo indeterminado. A característica essencial dos andarilhos, a errância, relaciona-se ao tema do exílio: o Judeu Errante é o "eterno" estrangeiro. Explicitamente referido na novela "Viagens de Ahasverus à Terra Alheia...", o judeu errante é "figura transicional que reúne as marcas do exílio judaico por todos os continentes até o dia de hoje [...]" (Waldman, 2003, p. 89). Essa marca de desenraizamento, grosso modo e sem a conotação antissemita da lenda ${ }^{123}$, é traço marcante do que se chama literatura judaica. Assim, essas marcas explícitas seriam traços da figura do Judeu Errante na escrita de Rawet, ou apenas mais uma evidência que não passaria de armadilha interpretativa simplificadora? A figura do Judeu Errante é reconhecível nos andarilhos de Rawet, especificamente?

Segundo Vieira, o Judeu Errante está intimamente ligado à busca por sentidos que, segundo o autor, caracteriza a literatura judaica de modo geral: "Intimately entwined are the 'wandering Jew' and the 'Jewish quest', wich stem from the experience of exile and return"' (Vieira,1995, p. 49, grifo meu). Nesse sentido, o autor toma o Judeu Errante, de um prisma histórico ("wich stem from": "que se origina de") e judaico, como um arquétipo que teria sua contraparte cristã: Entre parênteses, Vieira afirma que "(This archetypical myth is also nourished by its Christian counterpart: the wandering Jew at the time of Jesus)”. Assim, Vieira marca uma clivagem entre o prisma cristão e o judaico sobre essa representação arquetípica da errância e do exílio judaicos, a qual busco explorar doravante. ${ }^{124}$

Nesse contexto, o andarilho de Rawet seria, então, fruto da necessidade de uma postura que respondesse, recusando, ao projeto nacionalista e nivelador da ditadura nos anos 1960, bem como ao etnocentrismo da comunidade judaica. Ahasverus, enquanto contraparte antissemita do Judeu Errante, remete ao autor suposto de "Kelevim", que se auto-aliena

\footnotetext{
${ }^{123}$ O exílio também é parte da tradição judaica. Nesse sentido, ignorar o caráter antissemita da lenda do Judeu Errante teria como consequência a confusão da lenda antissemita com a tradição. Por isso, a chave interpretativa (i.e., os paradigmas) deve mudar, ao se passar do antissemitismo do qual a lenda se origina para a tradição judaica, em que o exílio obviamente tem outras conotações.

${ }^{124}$ O autor não faz mais referência à essa clivagem (cf. Vieira, 1995, “Introduction”).
} 
daqueles que teriam se beneficiado, de alguma maneira, com a "cafetinagem histórica que se faz com Auschwitz" (Rawet, 2004, p. 205) ${ }^{125}$.

Theophilo Braga afirma que a lenda do Judeu Errante, “cuja imortalidade é um castigo, operou-se como uma remodelação da lenda de Malco, já popular no século XIII, como se vê da gesta de Fierabras" (Braga, 1892, p. 235). Ainda segundo Braga, o Judeu Errante reúne a lenda do Preste João, discípulo longevo de Jesus, e do judeu maldito Malco, "que batera no Salvador" (de Paris apud Braga, p. 235). Ausubel (1989) afirma que a primeira referência ao judeu errante foi feita em "As flores da história" (1228) pelo monge inglês Roger de Wendover. Diz uma versão da lenda que Jesus, enquanto carregava sua cruz, tentou descansar em uma pedra. Mas um de seus atormentadores, o sapateiro Joseph Cartaphilus, não o deixou descansar. A resposta, segundo a lenda, foi de que o sapateiro não interromperia jamais sua própria jornada até a segunda vinda de Jesus (Parousia). A lenda baseia-se supostamente numa interpretação tendenciosa da seguinte passagem do evangelho de Mateus (16:28): "Em verdade vos digo que alguns há, dos que aqui estão, que não provarão a morte até que vejam vir o Filho do Homem no seu Reino" (Almeida revista e corrigida, versão online). Em resumo, é uma lenda não-judaica que remonta ao séc. XIII Segundo Ferreira (2000, p 1, grifo meu),

O que nunca fica omitido, no caso das versões que nos transmitem esta história, fragmentos de histórias ou cenas do judeu errante é o peso da punição, o viés maldito, danação por toda a eternidade. Deve-se porém levar em conta que a este herói se confere sempre a força da rebeldia e a virtude da esperança.

O viés ambíguo do "a imagem do venerável velho-homem, aquele que testemu-

\footnotetext{
${ }^{125}$ Mais uma vez, Rawet traz à tona seu conflito com o judaísmo (ou com os judeus), mostrando ser mais do que manifestações de loucura. O autor-narrador de "Kelevim" aliena também, consequentemente, seu próprio (projeto de) personagem, abandonando-o ao final do conto. Vamos "encontrar" esse personagem andarilho em "Crônica..." e Sôbolos..."; e esse autor (quando é de fato um autor, e não um projeto de autor) em "Reinvenção de Lázaro",
} 
nhou todos os males e guerras" (idem, p. 4), , é o viés geral que se entrevê à sombra do vagabundo, conforme será demonstrado. Esse mesmo viés torcido aponta para questões sobre alteridade e identidade (judaica).

No romance de Par Lagerkvist, Ahasverus é o judeu cujo testemunho valida e reafirma a salvação cristã procurada pelos peregrinos ${ }^{126}$ hospedados na taverna onde se inicia o romance. Num primeiro momento, ao tomar-se o Ahasverus de A morte de Ahasverus como a referência ficcional para se tecer considerações acerca da lenda do judeu Errante, cair-se-ia numa armadilha argumentativa de fundo cristão tanto popular como teológico $^{127}$. Tenta-se, dessa forma, eludir o iniludível, isto é, contornar as indefinições e ambiguidades constitutivas do andarilho rawetiano, ao tentar desviar-se da complexidade do desenraizamento relacionado à identidade (étnica, nacional, ou algo que responda ao "quem sou?") e subjacente ao andarilho rawetiano nos contos aqui tratados.

O judeu errante Ahasverus é o amaldiçoado que espera pela vinda do messias (a segunda, do ponto de vista da tradição cristã). Partindo desse pressuposto, algumas inferências podem ser feitas. Ahasverus seria aquele que deve esperar para ser salvo: nesse sentido, é figura universal do sujeito amaldiçoado que exatamente por isso pode (e deve) ser salvo, ainda segundo o cristianismo. Existe, portanto, uma meta a embasar a lenda: a salvação, pois o Judeu Errante, assim como todo judeu, é, do ponto de vista cristão, alguém que não aceitou Jesus como o messias.

O andarilho de Sôbolos... e o vagabundo de "Crônica...", personagens angustiados, buscam algo que sabem impossível: o apaziguamento de suas angústias e a plena consciência de si mesmos por meio do pleno domínio da palavra e da realidade. Entretanto, a leitura dos contos mostra como a plenitude é fugidia, frágil e ilusória ${ }^{128}$. A salvação, forma definitiva de apaziguamento se levar-se adiante o viés cristão da lenda, não é possível.

\footnotetext{
${ }^{126}$ O peregrino, assim como o Judeu Errante, é um estrangeiro: “Le premier sens de peregrinus c'est: l'étranger, l'exilé." Mas o peregrino despoja-se de sua identidade: "Mais le pèlerin, lui, n'est jamais chez lui ou Il marche: um étranger" (Gros, 2009, p. 149), e Ahasverus ( no romance de Lagerqvist) está sempre carregando sua punição: portanto, está sempre consigo mesmo (“chez lui ou Il marche”).

${ }^{127}$ Popular porque historicamente usado para justificar o antissemitismo; teológico porque envolve a figura do messias cristão. O romance de Lagerqvist pressupõe a primeira conotação e se baseia na segunda.

${ }^{128}$ Em “Crônica..”, por exemplo, percebe-se algo como plenitude na ligação estabelecida por uma fração de segundos, com a troca de olhares rapidíssima e enviesada, seguida por um sorriso visto e aceito (mas não retribuído) na penumbra, entre o vagabundo e a prostituta deitada no sofá.
} 
Num segundo momento, a figura do Judeu Errante, símbolo antissemita ao longo dos últimos tempos, seria "assimilado ao destino do povo judeu" (Novinsky in Amâncio, 2005, p. 30), transformando-se e universalizando-se como símbolo de estrangeiridade. A errância a prícípio sem fim, própria dos andarilhos de Rawet, parece transformar a carga de estrangeiridade de Ahasverus em maldição universal daqueles que ousam penetrar ou se descolar da superfície do senso comum. O vagabundo de "Crônica..." também se descola de e penetra a superfície, mas volta à tona transformado. Ele acaba estabelecendo uma relação peculiar com a noção de superfície por onde circula o senso comum. A epígrafe de Lagerkvist pode ser entendida como referência textual explícita ao judeu errante Ahasverus que persiste como lenda ou figura genérica diluída e pouco definida no imaginário literário, a despeito de seu fundamento antissemita originário no séc. XIX. É figura polissêmica diante da marca (estigma) de alteridade que caracteriza o "judeu genérico" e pode levar a outras generalizações relacionadas, chegando ao equívoco maior da demarcação da identidade do Outro: se o judeu é representante maior da alteridade, logo o Outro é aquele que carrega traços comumente associados ao judeu genérico: é o sujeito ético por excelência ("imperialismo ético" judaico), mas também o desenraizado-mor. Consequentemente, traços literários de desenraizamento e ética bastariam para caracterizar uma escrita qualquer de judaica.

Particularismo essencialista ou generalização homogeneizadora, sabe-se que esses são simplismos a serem evitado, assim como o fato de que o fato de ser judeu não basta para denominar judaica a literatura de Rawet ou qualquer outro escritor judeu. É exatamente esse risco que Rawet evoca na figura de seus andarilhos: Yehuda Bitterman, em "Reinvenção...", não procura deliberadamente apropriar-se do Outro conferindo-lhe quase que instintivamente - afinal, é um judeu - "traços judaicos" no conto que escreveria sobre um trabalhador braçal. Ao identificar Yehuda com Tião, o trabalhador surgido por acaso na imaginação do narrador Yehuda, formando um nó das intenções do narrador e estímulos sensoriais dos lugares por onde passa, Rawet sugere um exercício que é ao mesmo tempo literário e empático (e por isso, ético), demonstrando que toda personagem literária é necessariamente ficcional; não é o outro (com minúscula: alteridade genérica e inofensiva, porque mantém distância segura e impede a empatia), mas o Outro, forçosamente individualizado e diferente, e universal em sua diferença. Distancia-se para preservar a individualidade do Outro, mas não do outro, ideal de alteridade que achata as individualidades. 
Uma solução viável para o impasse criado pelo fantasma do Judeu Errante decorrente da epígrafe e dos nomes "Ahasverus" e "Samuel Rawet"129 seria descartar a solução facilitadora e homogeneizadora de se buscar traços judaicos em um autor judeu solução implícita na identificação do Judeu Errante ao andarilho rawetiano (em especial o vagabundo de "Crônicas..." ) - e assumir os riscos das indefinições rawetianas solidamente estruturadas e evidentes nos contos. Dessa forma, as várias pequenas epifanias horizontais vividas pelos andarilhos têm de volta sua devida importância nas análises, sufocada pelo fantasma do biografismo e, a reboque, do Judeu Errante.

Evitando soluções fáceis, o narrador-autor de "Reinvenção de Lázaro" decide-se arriscar-se e inicia sua história da seguinte forma: "Yehuda amassa as folhas de anotações, rasga algumas em branco ainda, lança os dois livros à sua direita sobre a cama, chuta a cesta debaixo da mesa, e resolve contar a história de Tião no momento em que percebe que ele era Tião (p. 309)"."Eu é um outro”. Quais as consequências dessa metaescrita? Decerto a percepção de que a mesma não muda o mundo (isto é, não se infere engajamento em nenhuma meta específica, nos contos), mas enriquece a experiência (Erlebnis, cf. nota 177) do leitor com um jogo ficcional que não transcende a experiência humana por meio dos lugares-comuns, mas os aponta, mergulha no lodo em que estão imersos, e os traz de volta à superfície, renovados.

Como termo-valise, panaceia ou representação arquetípica da alteridade, o Judeu Errante é uma figura que, por sua abrangência e indefinição, comporta temas decorrentes da alteridade, como marginalidade, preconceito, racismo e homofobia. $\mathrm{O}$ andarilho rawetiano evocaria, em traços gerais, o tema da alteridade, o qual permitira traçar linhas de força para fora dos contos aqui analisados e, dessa forma, relacioná-lo ao texto em que o indivíduo Samuel Rawet relata o encontro com o indivíduo José Marques da Silva. O resultado desse encontro é um ensaio em que citações de Diário de um candango estão entrelaçadas ao relato de Rawet. Um pensamento próprio depreendido da ficção rawetiana, e intrinsecamente ligado a esse universo, pode ser delineado nessa relação textual.

A questão da biografia na ficção sempre vem à tona quando se cotejam os ensaios e os contos metalinguísticos. Inevitável encontrar semelhanças e ecos entre a imagem que o próprio autor constroi - não como personagem, mas como autor - de si mesmo, diante do leitor que procura por vieses interpretativos mais adequados a sua obra ficcional. Os

\footnotetext{
${ }^{129}$ Respectivamente, referência direta ao romance que, por sua vez, evoca diretamente a lenda do Judeu Errante; e autor efetivo.
} 
personagens andarilhos surgem com força nesse outro fantasma surgido do confronto entre ficção e ensaios rawetianos, se for levado em conta que, no caso, ambos sejam formas híbridas.

Segundo F. V. dos Santos (2008), em sua “Apresentação" e "Introdução" à fortuna crítica de Samuel Rawet, afirma que a "mobilidade das interfaces de autobiografia e grafia do real faz parte da "ideia do novo na geração de 1950", que "incorporava o sentimento de intimidade com a presença da dimensão interior dos anos quarenta, a espontaneidade subjetiva da apreensão do mundo, a mobilidade das interfaces de autobiografia e grafia do real com a concretização de uma mímesis do mundo" ("Introdução", p. 35). O autor traça, aqui, o pertencimento de fato (e uma possível filiação) ao cânone ${ }^{130}$. Partindo de uma característica própria à literatura do séc. XX que deságua no intimismo do romance de 1930/40 ${ }^{131}$, e é perceptível durante o boom do conto, nos anos 1950/60, constatam-se também as "relações entre autobiografia, ficção e ensaísmo" no início dos anos 1970 (Assis Brasil in Santos, 2008), período de grande produção ensaística de Rawet; o "tratamento da matéria autobiográfica" (Santos, idem, "Apresentação", p. 23), que difere da mera "biografia empírica", segundo a qual o andarilho-vagabundo seria erroneamente identificado ao indivíduo (judeu-imigrante-escritor-engenheiro) Rawet, e não à "personagem” construída pelos ensaios.

Uma rápida mirada na relação entre autobiografia e ficção na literatura ao longo do séc. XX, ainda de acordo com F. V. dos Santos (2008), pode ajudar na contextualização da obra rawetiana como um todo. De acordo com o autor, na virada do séc. XX o narrador intimista já era visto no conto, romance ou ensaio, "em busca de uma língua, de um pertencimento, de uma pátria" ("Introdução", p. 38). Dos anos de 1980 até os anos 2000, tem-se a figura do "andarilho à deriva”, "também [assim como o narrador no início do século] em busca de uma língua, de um berço". No meio desse caminho, nos anos de 1950, tem-se, no "novo moderno", a "linguagem como meio de investigação existencial e busca de um cotidiano atualizado" (idem, p. 37). Procurava-se descobrir um novo olhar - e não criar: a nova forma da linguagem, parece dizer Santos, surgia da necessidade de uma nova forma de embate com a realidade bruta, passando pelo filtro da subjetividade do autor, que para

\footnotetext{
${ }^{130}$ Pertencimento de fato e de direito: refiro-me à posição que Rawet ocuparia no cânone (segundo o autor), no centro ou à margem, em posição peculiar ou ao lado de outros autores.

${ }^{131}$ Vide, dentre outros exemplos, Angústia (1936), de Graciliano Ramos.
} 
tanto se valia de formas híbridas ${ }^{132}$. A tradição, na forma do Modernismo de 22, passa pelo romance de 30-40 (os "gigantes nordestinos"); como referencial, seu campo de influências se estenderia à prosa urbana de Rawet e do grupo do Jornal dos Novos (coluna do jornal "A manhã" inaugurada por Dinah Silveira de Queiroz e liderada por Fausto Cunha), da "Revista branca" (1948-1957) e do grupo Café da manhã, que tinha uma coluna em "A manhã". Rawet fez parte de todos esses grupos. Um dos "gigantes nordestinos", José Lins do Rego, tem profundas marcas autobiográficas em seus romances, assumidamente de cunho memorialista (em especial os do ciclo da cana-de-açúcar).

Diante do andarilho rawetiano, o mundo pelo qual erra são espaços cujas fronteiras devem ser transpostas, rumo ao "fundo da existência", cuja superfície são as convenções sociais e o senso comum (dos quais os clichês são uma parte). Os momentos fugidios de gozo, como no final de "Sôbolos...", são os ápices da existência que, no entanto, logo se perdem, dando prosseguimento à eterna construção da consciência de si - na superfície. Pela lógica de "Crônica..." os que se dispõem a uma jornada como essa são os sofredores anônimos de que fala a epígrafe do conto, tirada de La mort de Ahasvérus: "Mais combien ont souffert sans que leur souffrance ait la moindre valeur?"

Ao mesmo tempo universal e atribuída à história judaica, a figura do Judeu Errante, quando apropriada por seu viés laico, pode compreender identidades variadas e não ter uma única caracterização. Isso é possível porque, por esse viés, sua origem é histórica mas seu substrato é universal, já que o mesmo é solo para questões como a crise identitária, o exílio e suas conotações: questões universais, humanas, conclui-se. Nesse sentido, não haveria, então, porque remeter-se à figura do judeu errante Ahasverus - laicizado ou não - e, por conseguinte, à lenda de Ahasverus, caindo no clichê judeu = exílio. No entanto, é necessário que se afaste esse fantasma, e nisso Rawet é original, ao propor a seu leitor questionar-se por que Ahasverus, que está na epígrafe de "Crônica...", não pode ser automaticamente identificado aos andarilhos.

Mesmo se afastado dos outros contos analisados neste trabalho, o fantasma de Ahasverus ainda persistiria em "Crônica...". Tome-se o velho de "Crônica...": como guia do andarilho, transmite-lhe seus valores. Esse vagabundo/andarilho se mostra, a princípio, uma tábula rasa que absorve e assimila (ou deixa de assimilar) os estímulos do mundo, louco e ingênuo. Mas aos poucos se revela um indivíduo lúcido que toma os estímulos do meio como pontos de partida para os questionamentos a que se propõe, conforme esses estímulos.

\footnotetext{
${ }^{132}$ Vide os ensaios-crônica nos anos 1960.
} 
A errância dos personagens de Rawet constrói-se - e reverbera por todo o conto, ao final do conto e na perspectiva do leitor - pela palavra carregada de potencialidades, estruturando (ou: compondo) uma linguagem que caracteriza universos aos quais se prendem por laços frágeis condenados a se desfazerem. A errância também é uma grande e instável metáfora construída sobre bases instáveis, no terreno textualmente delimitado e imprecisamente localizado entre leitor e obra, "ponto concreto de nosso contato entre o objeto e os nossos sonhos" (Rawet, 2004, p. 259). Atravessa-se e se é atravessado por territórios sobrepostos formados pelos passos de todos os que os palmilharam: assim, o que é particular, único, não deixa de ser fruto de uma disposição universal a procurar pelo "fundo obscuro da existência". Suas reminiscências o acompanham, assim como as memórias alheias, ou coletivas, até mesmo projeções passadas que não se cumpriram (desejos pendentes).

A subjetividade do vagabundo é onde se dá o impacto causado pelos encontros imprevisíveis. Subjetividade desarmada: indiferente, no sentido proposto por Flusser, ao olhar indiferente. O filtro do medo é a incerteza do que vai encontrar durante sua errância, e a certeza de que os impactos resultantes terão algum tipo de repercussão sobre si mesmo. No conto, as fronteiras entre individualidades são subjetivas, múltiplas, tênues e móveis. A palavra torna-se, como expressão subjetiva desse laço frágil que marca a condição do exílio interior, o único referencial espaço-temporal do sujeito desenraizado. Valores como “abjeção, a covardia, o ressentimento, o despeito são [ou: tornam-se, ou ainda: voltam a ser] armas, válidas, porque humanas" (idem, p. 213, grifo meu).

Em Rawet, o andarilho vaga pela inexplicável necessidade de movimento. Nos contos enfocados, o exílio, que seria o cumprimento da punição do Judeu Errante, não está presente, Apesar de pessimista, o anti-heroi rawetiano, ao fazer da necessidade de deslocamento o fundamento de sua existência, renega, odiando, valores e noções estáveis, com as quais tem familiaridade. Inclusive a ideia de punição. Em "Crônica...”, Rawet convida o leitor a se desprender de seus próprios pressupostos e acompanhá-lo numa caminhada - amaldiçoada ${ }^{133}$ como a do Judeu Errante - em que os únicos pontos de apoio são os rumos vagos que o vagabundo toma para si: o autoconhecimento e o mergulho nas profundezas de si mesmo. Diante da lenda cristã longínqua, mas indiretamente presente, e da imprevisibilidade da errância, o leitor é impelido a se deixar conduzir pelo vagabundo, que

\footnotetext{
${ }^{133}$ A figura de Ahasverus, o "heroi maldito" (como o flâneur baudelairiano), foi laicizada no final do séc. XIX.
} 
atualiza literariamente o mito romantizado ${ }^{134}$, ao final do séc. XIX, do judeu amaldiçoado com o desenraizamento e a marginalidade em relação aos valores dos quais participa ativa e passivamente. A lenda do Judeu Errante, na figura de Ahasverus, perde a conotação religiosa do exílio amaldiçoado, mas Ahasverus mantém-se uma figura maldita e errante - algo como o flâneur baudelairiano. Torna-se, então, o maldito rebelde, contraparte involuntária do andarilho.

Nesse sentido, o que entendo como exílio interior seria a nostalgia por um axis mundi ilocalizável que, entretanto, moveria a sucessão de sucessos e fracassos em que consiste a história da humanidade. Diz Ahasverus, personagem de "Viver" (in Várias histórias, 1896, Machado de Assis) ao dizer a Prometeu que este não conhece a vida: "Felizes os que só leram a vida em um capítulo. Os que se foram, à nascença dos impérios, levaram a impressão da perpetuidade deles; os que expiraram quando eles decaíam, enterraram-se com a esperança da recomposição”. A auto-entrega dos andarilhos à força centrípeta causada pela percepção do próprio exílio interior acaba por borrar a fronteira entre sonho e realidade, pertencimento e marginalidade, por dar ares de realidade ao sonho e viceversa. Nesta interminável e tensa zona de transição entre o eu e o objeto ${ }^{135}$, cada significante tem seu significado usual questionado, e palavras como margem, sociedade, sonho e realidade só se mantêm porque suas bases são minimamente mantidas. $\mathrm{O}$ vagabundo rawetiano seria um tipo de "pária da consciência", pela lucidez que demonstra quanto a sua própria condição humana; profeta de si mesmo que não quer salvar o mundo. Não há heróis redentores nem santos em Rawet, mas vagabundos malditos.

O lugar-comum é a unidade mínima do "real" - simulacro produzido pelo desejo de tornar o real ${ }^{136}$ visível. Atrela-se a comunidades imaginadas de consumidores de bens simbólicos, no caso da literatura: o judeu, o brasileiro, o suburbano etc.: "O 'real' [isto é, o simulacro do Real] é aquilo que, em cada lugar, a referência a um outro faz acreditar" (Certeau, 1994, p. 289). O apelo do lugar-comum é o pertencimento a um grupo, o que se expressa por sinais inteligíveis e aceitos pelo outro do mesmo grupo; esse apelo torna-se o canto da sereia quando mitificado, isto é, quando o signo a que se refere o senso comum é

\footnotetext{
134 “Ao final do séc. XIX, a imagem de Ahasverus tornou-se o símbolo privilegiado da alma errante e livre" (Novinsky, 2005, p.30).

${ }^{135}$ Isto é, sua própria materialidade literária.

${ }^{136}$ No sentido dado por Lacan. Cf. Roudinesco e Plon, 1998.
} 
naturalizado. Rawet problematiza esse senso comum que constitui o conhecimento cristalizado.

O que chamei anteriormente de "pequenas epifanias horizontais" seriam "simulacros de revelação" (Baptista, 2003, p. 254) ${ }^{137}$ em que a certeza da "revelação" trazida pelas epifanias revela-se insidiosa, capciosa, ou ilusória, mas nunca falsa, pois tem como reverso a dúvida que move a busca por sentidos (equivalente ao "mergulho em si mesmo") de que se alimenta o andarilho: dúvida que abre uma brecha na solidez ilusória do lugar-comum e permite sua desconstrução; que se alimenta de seus próprios destroços até a negação de si mesma em sentidos cristalizados, quando o ciclo se reinicia e a dúvida renasça.

O fato de se trabalhar com metalinguagem faz com que a "solidez" e a "estabilidade" sejam repensadas, de forma que a coerência textual não dependa delas embora se baseie nelas. O que se tem é um metadiscurso construído sobre bases que, paradoxalmente, procura-se negar em sua estabilidade. A ilusão de solidez do conceito é desfeita de modo que se vislumbre sua origem; a coerência do discurso é posta em dúvida, pelo questionamento de suas bases; a estabilidade do conto, formada pela "solidez" e "coerência" de suas bases (o lugar-comum enquanto sentidos cristalizados) tem no seu abalo a razão de ser do conto. Por isso, "Crônica de um vagabundo" pode ser imaginado como explosão reconstituída ${ }^{138}$.

O sentido é visto como algo a ser transformado, e para isso ele é desconstruído ao longo do conto, por um processo de liberação das suas potencialidades que dada forma cristalizada relegou a segundo plano, não conseguindo eliminá-las - daí a ilusão de solidez

\footnotetext{
${ }^{137}$ Segue a citação inteira: "Repare-se que, se não há uma medida comum, se não há um sentido garantido, se não há uma revelação possível, mas apenas simulacros de revelação, Brás Cubas não pode ser exemplo de coisa nenhuma”.

${ }^{138}$ Penso numa instalação de Cornélia Parker (Anexo 1, Fig. 1), em que uma cabana explodida tem seus destroços reunidos, sem se tocarem, por fios. A imagem da cabana é preservada pelos seus próprios destroços. Da mesma forma, o conto rawetiano metalinguístico, em especial os aqui selecionados, é formado pelos destroços daquilo que desfaz: o lugar-comum. Cortázar (apud Gotlib, 1990, p. 39) diz que o conto como forma literária é análogo a uma bolha de sabão: uma estrutura esférica, fechada, tensa e frágil, mas perfeitamente sustentada; imagem da condensação de fatos intensos. Relacionando a comparação à obra de Parker, o conto rawetiano seria como uma bolha - pesada, pontiaguda e cheia de manchas - cuja estrutura é formada por destroços ligados entre si por fios invisíveis, em cujo centro está o andarilho.
} 
do lugar-comum. Esse processo de inversões é o que move "Crônica de um vagabundo", onde o que é secundário torna-se primário, e vice-versa.

O que pretendo dizer com "vislumbrar a origem do conceito" liga-se ao que Barthes chama "grau zero da escrita": "é basicamente uma escrita indicativa" (2004, p. 65), ou seja, nem imperativa nem subjuntiva (em outras palavras, nem determinante, nem hipotética). Nessas "escritas neutras [...] pode-se facilmente discernir o movimento mesmo de uma negação [...], como se a Literatura [...] não mais encontrasse pureza a não ser na ausência de todo signo, propondo enfim o cumprimento desse sonho órfico: um escritor sem Literatura" (idem, p. 7). Predomínio do silêncio, diante da impureza (inevitável?) do signo. As palavras impositivas da personagem que gostava de ver as faíscas de maçaricos na madrugada, em "Crônica de um vagabundo", perdem força diante do lema indicativo do velho, constantemente repetido ao longo do conto.

Uma inverossímil linguagem íntegra levaria, idealmente, a um tempo e lugar onde a palavra cederia lugar à ação, conforme se vê numa passagem de "Crônica de um vagabundo"139:

Se fosse possível eliminar a palavra, a mentada e a falada. Seríamos objetos, viveríamos num mundo apenas de acontecimentos, e todos estritamente necessários. Reduziríamos a nossa inteligência ao fazer, e ao raciocínio destituído de vocábulos, que estaria implicitamente ligado à ação (Rawet, 2004, p. 240).

Mas não é possível eliminar a palavra, e o signo imperfeito e impuro por natureza continua a ser necessário. Inclusive os mitos modernos de que deriva essa relação incerta entre significado e significante diante dos sentidos atribuíveis. Diz Barthes sobre o mito moderno: “[...] a forma não suprime o sentido, empobrece-o apenas, conservando-o à sua disposição" ${ }^{140}$. Mais adiante, o autor afirma:

\footnotetext{
${ }^{139}$ É claro que o autor está sendo irônico ao testar a ingenuidade do leitor: Não se vê nenhum idealismo ou busca pelo paraíso perdido no conto. As palavras de ordem da personagem que havia dito essas palavras ao vagabundo quase desaparece sob suas palavras.

${ }^{140}$ Uma das formas tomadas pelo Judeu Errante é a do antissemitismo que levou a Auschwitz, levada em conta também nesse texto publicado 1967, quando o evento ainda era recente.
} 
O sentido passa a ser uma reserva instantânea de história, como uma riqueza submissa, que é possível aproximar e afastar numa espécie de alternância rápida: é necessário que ela se possa esconder nele. É este interessante jogo de esconde-esconde entre o sentido e a forma que define o mito (Barthes, 1993, p. 140).

O mito moderno de que fala Barthe (passim, 1993), como um lugar-comum, é instável, e sua desconstrução deve mimetizar essa instabilidade para ter sucesso. Assim, a lenda medieval do Judeu Errante, apropriada pelo antissemitismo moderno, é trazido à baila indiretamente e mantida à sombra do conto "num jogo de esconde-esconde entre o sentido e a forma". Fantasma esse que inevitavelmente entra no jogo de significações cujo eixo é o vagabundo. Assim, a morte e o sofrimento de um ("sa souffrance e sa mort”, na epígrafe a “Crônica..."), que representa o "maior evento que o mundo conheceu”, contrapõe-se ao sofrimento e à morte de uma multidão anônima e comum. Esse "um" distinto, Jesus, é posto ao lado, e não à parte nem acima, de um membro individualizado dessa multidão anônima: o vagabundo de "Crônica...".

Rawet traz esse mito/lenda na epígrafe, de "Crônica...", desconstroi-o e chega ao cerne de sua constituição: a alteridade, fonte neutra a priori da discriminação e do preconceito. A epígrafe do conto demonstra-se, portanto, que o autor levou em conta maliciosamente - a figura de Ahasverus. Diante da ausência de referências precisa que guiem o leitor por textos intrincados como os contos analisados, o senso comum e os clichês surgem do entorno em que se inserem tais textos, como caminhos certeiros de interpretação. O resultado, no entanto, é uma interpretação improdutiva, porque acaba por reafirmar clichês e o senso comum. Entretanto, nos contos em que se desconstroem o lugar-comum, os recursos facilitadores da interpretação são paradoxalmente assimiláveis aos próprios textos. Incorporam-se os paradigmas-fantasmas do entorno desses textos, um dos quais é a figura do Judeu Errante. Aqui, Ahasverus oferece-se insidiosamente como significante-mestre para a discussão de temas como a alteridade, a errância e o desenraizamento - que, por fim, levam ao clichê judeu=exílio.

Num texto literário tomado como microscosmo individual instável e de fronteiras borradas, a partir do qual são negociados os usos e costumes (lugares e convenções), um 
espaço $^{141}$ percorrido é apenas uma das inúmeras possibilidades de configuração do lugar ${ }^{142}$ próprio de onde se fala. $\mathrm{O}$ espaço entre leitor e texto tem formas indefinidas e ilusórias que podem ser equivocadamente tomadas como verdadeiros "objetos textuais": um lugar assinalado, um traço definido que remeteria a um tema, um personagem que remeteria a uma lenda. "Impurezas" que impedem leituras do real, i.e., a percepção de configurações espaciais do lugar que se inscrevem de dentro para fora e se leem de fora para dentro, seguindo linhas de força projetadas pelo conto, e sobre ele (pelo leitor), formando uma esfera de contornos borrados onde são traçáveis circunferências cujos eixos são o andarilho. Uma narrativa escrita, no entanto, é espacialmente linear. O lugar como ordem de coisas, ao ser apropriado fugazmente, propicia a criação coletiva, por meio das leituras de um mesmo texto literário, de trajetos individuais sobrepostos, que se tornam, assim, familiares a todos. Diferentes espaços textuais - descrições de diferentes leituras - seriam, então, relatos de vivências (comuns, usuais) de lugares em comum (compartilhados), nos termos de Certeau. Os lugares-comuns de Rawet seriam basicamente esses cruzamentos de percursos entre o texto e o leitor, formando pontos nodais.

Os contos com andarilhos inscrevem textualmente a cidade por onde erram (Crônica...", "Sôbolos...", "Kelevim”). Os andarilhos vivem "nos interstícios dos códigos que desmancha[m] e desloca[m] [...]"143 (Certeau, 1994, p. 216). São “delinquentes" cujos relatos, dos quais são o núcleo e personagens principais, "instaura[m] uma caminhada ('guia') e passa através ('transgride')" (idem, loc. cit.).

Enunciar é análogo ao caminhar: "O ato de caminhar está para o sistema urbano como a enunciação (o speech act) está para a língua ou para os enunciados proferidos" (Certeau, 1994, p. 177). Mudando os termos da comparação, tem-se que o ato de escrever está para o texto escrito assim como a enunciação está para a língua ou para os enunciados proferidos. Ler um texto é desvelar seus caminhos: o lugar do leitor “não é aqui ou lá, um ou

\footnotetext{
${ }^{141}$ Certeau (1994): Espaço "é um lugar praticado". O autor faz uma analogia entre espaço percorrido e leitura; "a rua geometricamente definida por um urbanismo é transformada em espaço pelos pedestres. Do mesmo modo, a leitura é o espaço produzido pela prática do lugar constituído por um sistema de signos - um escrito" (p. 202, grifo meu).

${ }^{142}$ Certeau (idem): Lugar é a “configuração instantânea de posições. Implica uma indicação de estabilidade" (p. 201). É a ordem "segundo a qual se distribuem elementos nas relações de coexistência”. É, portanto, individual: os elementos considerados não ocupam o mesmo lugar, mas coexistem lado a lado - no mesmo lugar, em espaços diferentes.

${ }^{143}$ Desmancham e deslocam: reelaborar, desconstruindo (literal e metaforicamente),os signos.
} 
outro, mas nem um nem outro, simultaneamente dentro e fora, perdendo tanto um como o outro misturando-os, associando textos adormecidos, mas que ele desperta e habita, não sendo nunca o seu proprietário". É no leitor que se efetua a revitalização do lugar-comum provocada pelo conto e suas linhas de força. Caminhar, escrever e ler são atos muito próximos, fato atestado pelas metáforas que entrelaçam esses termos: "ler o mundo", "descrever um trajeto", "abrir caminhos no texto" etc. Deslocamentos do eixo interpretativo formado pelo andarilho podem ocorrer se tomarmos o autor como novo eixo. A imagem que um autor faz de si mesmo pode ser reveladora sobre seu projeto literário e sua consistência. Rawet não declarou explicitamente um projeto, mas seus ensaios e artigos expõem visões assertivas sobre si e seu entorno.

Com base nas ressalvas acima, algumas conclusões sobre biografia e sua implicação indireta, o Judeu Errante, já podem ser feitas.

Os contos analisados, cujos eixos são os andarilhos, estão coalhados de elipses, dualidades e ambiguidades que pedem por pontos de apoio fatalmente transformados em facilitadores da leitura, concessões ao leitor descuidado que identificaria a errância dos andarilhos rawetianos com a origem judaica do autor, trazendo para o texto ficcional um dado biográfico facilitador, e por isso mesmo equivocado. O conhecimento dos ensaios também contribuiria para isso. Criar-se-iam expectativas cujos cumprimentos equivaleriam à descaracterização do texto de Rawet. O que significa que depreender a figura do Judeu Errante, no modo como é conhecida popularmente (o judeu condenado a vagar pelo mundo até a segunda vinda do messias cristão), e diante de evidências frágeis (a epígrafe e o velho de"Crônica..."; a errância), é incorrer na leitura simplista a que textos complexos como “Kelevim" e "Crônica..." estão sujeitos ${ }^{144}$. Portanto, identificar errância com exílio é trazer inadequadamente um dado sobre o autor que, se apenas tomado como um traço generalizado abstraído da denominação "literatura judaica", mostra-se gratuito. Seria, enfim, a tradução interpretativa da armadilha do biografismo que, no caso de Rawet, consistiria em cair no clichê judeu $=$ exílio e procurar marcas de judeidade que justificassem a denominação "literatura judaica" sob a qual esse autor se encontra em parte de sua fortuna crítica. Seria, também, uma apropriação a-histórica de marcas distantes de um mito originariamente antissemita, o mito do Judeu Errante, tendo como consequência a naturalização do

\footnotetext{
${ }^{144} \mathrm{O}$ mesmo ocorreria com uma leitura que se limitasse a procurar por aspectos judaicos do texto de Rawet, o que fatalmente cairia numa espécie de "cafetinagem histórica que [ainda se faria] com
} Auschwitz". 
antissemitismo que perpassa o histórico de atualizações do mito do Judeu Errante. ${ }^{145}$ Levando adiante essa lógica, o binômio judeu = exílio (e vice-versa) seria marca homogeneizante de estrangeiridade (e, por isso, de distanciamento) que bastaria, supostamente, para dar especificidade ao autor ou personagem judeu, incluindo desde os personagens religiosos europeus das anedotas hassídicas (Buber, Peretz, Scholem Aleichem) até autores judeus imigrantes perfeitamente integrados à sociedade de chegada, como Clarice Lispector e Samuel Rawet.

Não se pode identificar ${ }^{146} \mathrm{o}$ andarilho rawetiano com o Judeu Errante porque não há sinais disso, apenas indícios insuficientes; não há expatriação ou degredo (exílio), mas “andar sem rumo certo; vaguear, percorrer" (errância) ${ }^{147}$.

A dificuldade diante do texto rawetiano coloca o risco de se cair no clichê "judeu = exílio". Diante desse pressuposto, ter-se-ia o judeu como o desenraizado/exilado por excelência. Diante dessa constatação insinuada na lenda que se tornou mito, a figura do Judeu Errante seria neutralizada, se universalizada: no fundo, o Judeu Errante poderia assumir qualquer forma de exílio. Mas a consequência disso é que a figura se descolaria da lenda medieval e do mito moderno, perdendo, assim, sua carga histórica e naturalizando-se. O que não faz sentido nenhum (a figura descolada de sua própria lenda). Então a carga antissemita permanece, tendo sido usada pelo nazismo como mito moderno, isto é, deshistoricizada. A seguinte afirmação sobre o mito do golem vale para a des-historização do Judeu Errante:

Pois, se definirmos o mito como uma entidade atemporal, e mesmo eterna, estaremos afirmando, ao mesmo tempo, que o mito segue uma matriz invariável e que sua fonte não pode ser racionalmente reduzida. $O$ mito $^{148}$ transforma-se em fantasma, em projeção ideológica indissociável do povo do

\footnotetext{
${ }^{145}$ Em resumo, seria como abrir um pressuposto lógico segundo o qual qualquer visada sobre a lenda medieval do Judeu Errante teria de tomar seu caráter antissemita como ponto pacífico, dispensando problematizações que teriam por objetivo desnaturalizar o mito. Nesse sentido, o uso da figura do Judeu Errante é uma armadilha conceitual, devendo ser evitado.

${ }^{146}$ Mas pode-se aproximar, conforme demonstrado acima..

${ }^{147}$ Dic. Eletrônico Houaiss, verbete "errar".

${ }^{148}$ O autor fala no mito segundo Barthes (1993), em que o signo é naturalizado como significante, perdendo, nessa passagem, os fatores que o formaram.
} 
qual surgiu [...] (Diniz in Nazário e Nascimento (orgs.), 2004, p. 96, grifo meu).

Indissociável porque se tornou um estigma. Ante o impasse provocado pelo "mitofantasma", aproximar-se do autor e de sua biografia segundo ele mesmo (ou seja, seus ensaios-crônicas) corresponderia à necessidade de desfazer-se desse verdadeiro lugarcomum da condição/literatura judaica, dando contornos próprios, peculiares, ao autor.

Nesse sentido, "Diário de um candango" mostra Samuel Rawet como andarilho e personagem involuntário de si mesmo - e como autor à procura de outro autor. A comparação do andarilho ficcional com "Diário de um candango", passando pela figura do engenheiro-escritor (que, no ensaio, se define em relação ao candango-escritor), traria luz às concepções literárias sobre autoria e ficção: “O que eu tinha em mãos ainda não era ficção, mas o autor ali estava presente" ("Diário..." in Rawet, 2008, p. 163), referindo-se a Marques da Silva.

O mesmo Rawet que se desloca para Vila Planalto em busca de Marques faz questão de mostrar-se assumidamente parcial diante do livro do amigo Renard Perez, em considerações "nunca objetivas" (idem, p. 166), na crônica-ensaio sobre Começo de caminho: o áspero amor (1967). Em ambos os casos, mantidas as diferenças literárias entre as memórias e o romance, Rawet deixa claro que se recusa a tecer considerações neutras e $\operatorname{rigorosas}^{149}$.

Diante do que foi exposto, conclui-se que detectar o um Judeu Errante reformulado é possível nos contos escolhidos, mas também é improdutivo. Ter-se-ia um judeu universalizado que cairia numa generalizante exaltação romântica do herói maldito, e se perderiam de vista os andarilhos e a especificidade do conto de Rawet. Por outro lado, o movimento contrário, do clichê ao texto, passando pelo autor, pode ser produtivo: sua aproximação como mito moderno, e não sua identificação com o andarilho, é que é produtiva.

Mesmo a acepção de Judeu Errante de que me valho como mito-fantasma pode ser traçada historicamente: o Judeu Errante laicizado é o "símbolo privilegiado da alma errante e

\footnotetext{
${ }^{149}$ Mantém-se, assim, fiel ao próprio estilo dispersivo de suas crônicas-ensaio, em que autores de várias nacionalidades são citados, traduzidos ou no original, mencionados ou mesmo vagamente parafraseados ("E relembro também um outro [episódio] [...] que li em qualquer parte, se é que li [...]”, idem, p. 168).
} 
livre" (Novinsky, 2005), que vai dar no flâneur baudelairiano, que por sua vez é um andarilho, mas não um exilado. Retomando os parênteses de Vieira, citado no início deste capítulo, pode-se dizer que a errância em si tem sua contraparte antissemita e ideológica da qual paradoxalmente se alimenta. Essa "face" indesejada projeta-se sobre a outra, que é marca identitária (judaica, se vista do prisma judaico). O que não significa que seja aceita, e sim que seja trazida à baila pela figura do vagabundo andarilho.

O judeu exilado e a "alma errante e livre" transformam-se, finalmente, nessa peculiar síntese representada ficcionalmente pelo andarilho rawetiano.

\section{8. $O$ candango e o engenheiro}

Blocos de verdade / sobrevoam / superquadras / imaginárias // superquadras / à procura / de / uma cidade

(Nicolas Behr, revista "Piaû́”, n. 70) 
Os ensaios de Rawet, organizados e republicados em 2008 por Rosana Kohl-Bines e Leonardo Tonus, podem servir como súmula das referências ideológicas, filosóficas e literárias do escritor. Neste capítulo, será analisado o misto de ensaio, crônica e resenha "Diário de um candango", procurando refletir sobre inferências possíveis a partir dos ensaios como material de apoio para a interpretação dos contos ("Kelevim", em especial).

Em A hora da estrela, diz Rawet, Clarice redescobre a palavra "em sua função de linguagem, coisa talvez desconhecida por [ela] em sua infância e adolescência, no ambiente familiar, mas apreendida no meio não-familiar. E Clarice é nordestina" (Rawet, 2008, p. 222). E Rawet é suburbano carioca. Rawet enquanto suburbano carioca, e Clarice enquanto nordestina (idem, loc. cit.), redescobrem a relação entre a palavra e a realidade que procura capturar ("a palavra em sua função de linguagem"). Na esteira do ensaio de Rawet sobre Clarice $^{150}$ e nos termos estabelecidos pelo autor, tento responder à seguinte pergunta: Seria como escritor-suburbano carioca que o engenheiro Samuel Rawet descobriria a periferia de Brasília, Vila Planalto?

Brasília, inaugurada em 1960, foi construída pelos chamados candangos, trabalhadores (nordestinos, em sua grande maioria) da construção civil que acabaram por estabelecer-se na periferia da nova capital, formando cidades-satélite e favelas. O próprio Rawet, engenheiro calculista que trabalhou na construção da cidade, terminaria seus dias numa cidade-satélite de Brasília, Sobradinho. É numa daquelas favelas construídas por candangos que se passa Diário de um candango, em que o narrador, José Marques da Silva, um goiano de vinte e dois anos, dono do bar e restaurante São José, narra o cotidiano monocórdio e agitado da Vila Planalto. As chuvas fortes alternam-se com o calor excessivo; os fregueses compram fiado e nunca pagam; os ratos engordam com o pouco que se tem na cozinha enlameada após as chuvas, que deixam o barraco com água pelos joelhos e danificam outros barracos, reconstruídos com a mesma regularidade das chuvas e do calor.

Nas memórias, a história de Brasília está apenas no começo, mas os problemas sociais como subemprego, alcoolismo, abuso policial e desemprego ajudam a cimentar a relação do candango com a capital recém-inaugurada. Os trabalhadores nordestinos, mormente os cearenses, são os desenraizados que tentam se estabelecer e prosperar,

\footnotetext{
150 “A Hora da Estrela ou as frutas do Frota, ou um ensaio de crítica literária policial " (1979). Cf. capítulo 4 desta tese.
} 
deslocando-se pelos canteiros de obras gigantescas que são feitas naquele tempo. Escreve Marques da Silva, após decidir vender seu bar, no final do livro:

E Brasília, candango?

Brasília para nós foi uma ilusão.

Deixe Brasília milionária. Vá para a lavoura, que de seus esforços precisa.

Em três anos organizará a sua vida, que até agora você não organizou.

Para você, como para mim, tudo não passou duma grande ilusão. Vamos trabalhar, candango. Eu vou fechar o Bar e restaurante São José e também vou me fixar em outro lugar.

O autor acredita que ainda pode contribuir para o progresso de sua terra natal:

Sou goiano, vou trabalhar na ferrovia que vem para Brasília, ligando-a a Pires do Rio, a pulquérrima cidade de Goiás.

Vou ver o que lá acontece; depois lhe contarei tudo [dirigindo-se ao leitor].

(Marques da Silva, 1963, p. 148)

A saída de Brasília é vista como a persistência na busca de um progresso que, se não for pessoal, poderá ser da terra natal, Goiás. Essa esperança se expressa em palavras sobre o ano vindouro, 1962, ao descrever a enxurrada de lama causada por mais uma tempestade: "Vendo-se a lama que corre na rua, tem-se a impressão de que com ela corre o ano que tantas ocorrências desagradáveis nos trouxe" (idem, p. 143). O tom monocórdio dos diários reflete a esperança insistente de Marques em prosperar em meio a condições adversas que não mudam.

Rawet leu o Diário... e tentou encontrar seu autor. Escreveu um ensaio cujo título é o mesmo do livro (cf. Rawet, 2008, pp. 161-165). Nesse curto ensaio, o típico personagem andarilho rawetiano parece ter sido personificado pelo próprio autor. Ele "[e]stava decidido a não pedir informações a ninguém [em sua busca]. Utilizaria como elementos de referência reminiscências de leitura, o nome do bar, o parque de diversões etc." (idem, loc. cit.). Aquela era uma "paisagem frequente e comum para quem tenha o hábito de em qualquer cidade ir um 
pouco além do centro aprumado ou dos quarteirões confortáveis [...]” (idem, loc. cit.). Hábito que o próprio Rawet tinha, a julgar pelos ensaios-crônicas publicados em jornais, revistas ou em brochuras auto-financiadas. Revê "barracos, lama, valas, rádios a tocar bem alto em minúsculos quartos" (idem, loc. cit.). Nada que o ajudasse e encontrar o bar: uma paisagem como as outras que o autor conhecia. Desiste da procura, mas a retoma no dia seguinte, e encontra José Marques da Silva. Há uma configuração de elementos - o nome do bar, a disposição dos lugares da vizinhança, bem como outras referências da leitura do Diário própria do universo de Marques da Silva, pelo qual Rawet tenta localizá-lo. As memórias de Marques levam direto ao seu autor, sujeito único dentre os muitos candangos habitantes de uma vila periférica como tantas outras. Rawet decide-se então a retomar a busca perguntando pela localização não do bar, mas de um circo que haveria nos fundos do bar-restaurante.

O relato do encontro com Marques Silva é intercalado com transcrições de trechos do Diário..., sem que Rawet indique claramente a transcrição; há indicação de dia e mês, mas não do ano. Para o leitor que não conhece o Diário..., todo esse ensaio-crônica pode passar por texto de Rawet. O diálogo entre o ensaio e o livro existe e é estreito, razão pela qual a leitura de ambos, cotejada, mostra-se produtiva ao expor claramente o texto como um amálgama entre o relato (biográfico, assim como o diário) da andança de Rawet com o autor do Diário pela Vila Planalto e o próprio Diário: além das citações sem indicação, há informações atualizadas ${ }^{151}$ sobre a Vila Planalto que complementam as do livro. O texto convida o leitor a ler também o diário, ao selecionar passagens que revelam percepções poéticas de Marques Silva, contrariando assim a primeira reportagem sobre seu livro, comentada durante o encontro:

José Marques da Silva [...] fala com descontentamento sobre a primeira reportagem publicada sobre seu livro, em um jornal de Brasília. Lamenta que só queiram ver em seu Diário um roteiro de misérias e tristezas, de pobreza e humilhação. Acha que não deram importância ao outro lado, ao aspecto alegre e belo que soube vislumbrar naquele aglomerado humano (Rawet, 2008, p. 162).

\footnotetext{
${ }^{151}$ O ensaio foi escrito em 1963, dois anos após a escrita do diário.
} 
Lado esse que dá o tom pessoal às memórias e que Rawet destaca em seu ensaio, com citações pouco sinalizadas em que Marques fala do canto e da coragem dos nortistas, da paisagem do cerrado (sobre a qual há muitas passagens do Diário).

Rawet teve acesso aos manuscritos originais do Diário. Dá a entender que os consulta enquanto escreve o ensaio, em busca apenas de informações biográficas: "Enquanto folheio os cadernos que serviram de manuscritos para o Diário, e completo algumas informações biográficas meio esboçadas no livro, procuro ordenar na memória o que já foi escrito sobre a construção da nova capital [...]". Desdobrando o particular (próprio), ao geral (comum), Rawet tenta entender o Diário como parte de um processo já iniciado: o da construção da história - e posteriormente da memória - de Brasília. Tenta localizar a memória referente ao Diário num panorama histórico, ou do que é entendido como necessidade identitária da nova capital: "quando surgirá Brasília como cenário de ficção, quando surgirá um autor de Brasília?” (Rawet, 2008, p. 163). Procura desmentir o “jornal de Brasília” que buscou encaixar o clichê redutor da miséria ao candango, fechando os olhos do leitor daquele jornal para o esforço pessoal contrário à diminuição pela pobreza e pela falta de perspectivas em que se constitui o Diário. Rawet reforça esse movimento de resistência pela memória ao publicar seu ensaio em um periódico, corrigindo o erro simplificador do tal jornal. Diz Rawet: “o que eu tinha entre as mãos ainda não era ficção, mas o autor ali estava presente" (idem, loc. cit.). Pode-se concluir, então, que a memória viria antes da ficção, e seria seu requisito?

Apesar do tom de crônica desse ensaio, e dos contos constituídos por esquemas narrativos ("O logro, "fé de ofício" etc.). ou divagações filosóficas, Rawet mostra ter consciência de que autobiografia pura e simples não é ficção. Sua ficção demonstra muito mais trabalho com os sentidos de cada palavra e com a estrutura textual, encontrados apenas em parte em alguns de seus ensaios.

Rawet relata então que pediu a Marques para acompanhá-lo pela Vila, indicando-lhe "alguns lugares de referência constante em seu Diário" (idem, loc. cit.). Compara a configuração atual da cidade com a configuração da Vila no Diário. Em pouco mais de dois anos, muita coisa muda: "A Vila Planalto, no início apenas um acampamento de obras, enquanto erguiam os monumentos da Praça dos Três Poderes e a Esplanada dos Ministérios, é hoje uma cidade conquistada entre o lago e a estrutura do Tribunal de Contas" (Rawet, 2008, p. 164). "Cidade conquistada" e "improvisada que se afirma". A consolidação de Vila Planalto é sinal de resistência ou insistência? 
Rawet finaliza seu texto com uma frase que, sem sua referência (i. e., a morte do cartunista Péricles, criador do personagem de quadrinhos Amigo da onça), reforça o apelo à leitura do Diário... ao destacar o lirismo da frase - efeito que se tem diante das outras citações e do comentário final do autor do ensaio, antes da citação que encerra o ensaio: "É um testemunho que afirma, negando" (idem, p. 165). Afirma o quê? Nega o quê? A vida que corre naquele ambiente, em que Marques Silva destaca o bom humor e a criatividade dos cearenses da Vila. Nega a esperança na possibilidade de prosperidade à maioria, mas afirma a tenacidade do candango em viver na adversidade, manter o espírito vivo. Afirma a resistência dos que ficaram e consolidaram a Vila. Dualidades que se equilibram: a pressão social massificadora (pelo jornal, pelo abandono dos trabalhadores após as obras) enfrentada pela resistência do candango. Preserva-se a individualidade da ameaça niveladora e massificadora da mídia (o "jornal de Brasília") e do olhar que se pretende livre de responsabilidades ao naturalizar, sedimentando em senso comum, a miséria, pobreza, tristeza e humilhação vistas no livro de Marques pela reportagem do jornal.

A citação final: "Dia 31 de dezembro - Domingo./ A primeira madrugada do ano foi fria e triste." (idem, p. 164). Um mal presságio para o ano vindouro. Por quê? A resposta, parece apontar o autor, deverá ser buscada com a leitura do Diário. Ou mesmo na paciente observação do "ambiente operário real e generalizado" (idem, loc. cit.) dos que habitam os locais distantes do "centro aprumado", como os candangos de Brasília, cujo espaço emblemático é o Cacique bar, local de diversão agitado e tenso, mas vivaz, com muito álcool, mulheres, conversas, cantorias, brigas.

$\mathrm{O}$ ato de afastar-se do centro liga o Rawet ensaísta ao andarilho rawetiano. Indo mais longe, o candango, representado individualmente por Marques da Silva, é posto sob o olhar do escritor Rawet, que em "Kelevim" imagina uma cidade sem história e um personagem abandonado pelo seu próprio autor. $\mathrm{O}$ encontro do engenheiro calculista de estruturas com o candango operário liga metaforicamente, no plano literário (i. e., pelo ensaio de Rawet), dois pólos sociais da construção de Brasília: o centro e a margem, respectivamente o que foi planejado e o que surgiu da resistência às condições ruins e da insistência na busca pela prosperidade. Naquele ano de 1963 a capital já tinha sido inaugurada, e as cidades-satélites estavam se fixando. Brasília tinha atrás de si um projeto arquitetônico e de engenharia, e também político, estabelecido; Vila Planalto, por outro lado, era "apenas" uma cidade espontânea, refugo da construção planejada de Brasília. A oposição centro-periferia define-se ainda mais se se entender que a história da capital podia, no tempo em que o ensaio foi 
escrito, ser rastreada na história oficial brasileira, enquanto Vila Planalto só disporia, provavelmente, de fontes não-oficiais: seus habitantes ou algum curioso ou estudioso que se disponha a conhecê-la.

A ligação entre Rawet e Marques é feita pelo Diário..., um livro que não é ficcional, mas que já aponta um começo dessa memória da margem. A reação de Rawet também veio na forma escrita e semificcional, devido à estrutura do ensaio, que se entrelaça às memórias de Marques pelo recurso das citações incompletas, as quais parecem fazer crer que sejam referentes ao encontro com Marques. Portanto, Brasília é descrita a partir da margem, Vila Planalto, cuja história passa a fazer parte da história da capital quando o livro e o ensaio são publicados e tomam- valor de documentos históricos. Dualidades constitutivas (centro/periferia), cidade imaginada: Pode-se ver uma relação indireta, mas existente, entre a nova capital, construída a partir do nada, e a cidade imaginada, construída a partir da experiência de seu narrador-autor, de "Kelevim".

Vila Planalto é inevitavelmente lembrada quando se lê "Kelevim", uma cidade imaginada cuja dinâmica é descrita generalizadamente ${ }^{152}$ ao longo do texto e permanece para além da leitura, assim como o Diário... (o livro). Não se trata de simplesmente evocar a biografia do autor, mas de apurar suas marcas num conto ("Kelevim”, neste caso): as preocupações de um engenheiro que se afasta do "centro aprumado" que seria seu "lugar social natural", e busca o lado precário e esquecido. Extrapola, assim, o lugar que lhe foi reservado (o centro) para tomar contato (e assim inserir-se, de alguma forma) com regiões periféricas $^{153}$.

"Kelevim” é um conto sobre escrever um conto, exercício de imaginação (literária, eminentemente) que demanda uma completude recusada pela própria estrutura do conto, coalhada de elipses. Diante dessa estrutura, o leitor pergunta-se: como definir e interpretar a cidade Kelevim? Quem é o personagem abandonado pela imaginação do autor, fugindo assim aos olhos e à imaginação do leitor? Mais ainda: seriam essas as perguntas certas diante de um texto como esse?

Como e quem: perguntas que definiriam os rumos do conto abortado dentro do conto, se fosse escrito. As elipses do conto trazem à tona procedimentos literários tais como personagem e cenário - elementos básicos de um conto. Nesse sentido, é exercício de metaescrita (um conto sobre um conto a ser imaginado, numa gradação decrescente que só

\footnotetext{
${ }^{152}$ Como o ambiente de Vila Planalto.

${ }^{153}$ Um equivalente geográfico da extrapolação do lugar-comum na linguagem.
} 
terminaria no silêncio). "Kelevim" é experimentação formal, abordando a criação da problemática (se for considerado "Diário de um candango") e à problemática da criação, ao referir-se à cidade inexistente chamada Kelevim. Fracassa nesta empreitada, mas tem sucesso naquela: Kelevim continua não existindo, mas seu fracasso enquanto cidade imaginada constitui, por si só, um conto (abortado). Mas o conto embrionário torna-se, então, um conto acabado, e a problemática da criação efetivamente surge, pois Kelevim é "produto da pura imaginação".

O ponto de partida é minimamente delineado: o cenário e o personagem. O conto em si, "Kelevim", lança bases mínimas para a estrutura de um espaço ficcional, bem como para seu personagem, cujas angústias e anseios são pouco definidos, mas apreensíveis pelo leitor. Com isso, linhas de força são tracejadas (isto é, sugeridas) e apontadas para direções tão múltiplas quanto imprevisíveis - afinal, o conto dentro do conto não existe, mas é sugerido. Tendo como origens tanto as contradições de Kelevim como as necessidades e angústias do personagem, essas linhas se cruzariam e formariam nós de sentido. Os nós de sentidos potenciais surgidos das experiências resultantes do personagem naquele cenário é que dariam formas ao conto dentro do conto (sua trama, fábula etc.). Mas não definem essas linhas, apenas sugerem-nas. Quais as consequências dessa metaescrita? Em outras palavras, o que "Kelevim" demanda da imaginação do leitor?

Talvez uma resposta simples, que pode ser vista como verdadeiro lugar-comum da linguagem coloquial, seja: Perder-se. O conto pede que o leitor se perca junto com o personagem, um andarilho a princípio. Assim como o ensaio "Diário de um candango" claramente traz para si o livro Diário de um candango ao reelaborar as citações, destacandolhes o "acento pessoal" do testemunho de Marques, tanto "Kelevim" como a cidade percorrida em "Crônica de um vagabundo" podem ser evocadas aqui em sua proximidade temática - são cidades imaginadas percorridas por andarilhos imagináveis ${ }^{154}$ - e em sua unidade estrutural - ambos estão em Os sete sonhos, de 1967. Brasília começa a ter sua história com testemunhos como o de Marques; Kelevim é uma cidade que pede por sua história. Essa lacuna funcional salta aos olhos durante a leitura do conto, e o personagem que daria voz à cidade é abandonado pelo próprio narrador-autor. Tanto Kelevim quanto Brasília são criações (literária e urbana, respectivamente) a serem interpretadas por meio de textos de

\footnotetext{
${ }^{154}$ Imaginados, ou quase: em "Sôbolos...", "Reinvenção..." e “Crônica...", de um lado, e em "Kelevim” de outro.
} 
naturezas diversas: um conto (“Kelevim”), um livro de memórias (Diário de um candango) e um ensaio que os une.

Kelevim, cidade inventada (como Brasília) e descrita em termos vagos, é o espaço onde vive o vagabundo, assim como a Vila Planalto era o espaço em que vivia o Marques da Silva do Diário... É fato que a imagem que motivou Rawet a procurar Marques veio do livro, e não do conhecimento pessoal: tanto Marques da Silva como a Vila Planalto existiam de fato. Brasília e sua história são o repertório comum a ambos, Marques e Rawet, embora estejam em locais distintos nessa história como candango e engenheiro, respectivamente. Essas são as referências extratextuais, panos de fundo das memórias e do ensaio. São histórias pessoais que literalmente acabam por se cruzar na periferia de Brasília, legitimando, de certa forma, por um personagem central de Brasília, o impulso inicial para uma literatura que tem a nova capital como cenário, produzida por um personagem periférico de sua história oficial.

Brasília deveria existir como cenário literário, para existir de fato, e essa era uma preocupação de Rawet. Analogicamente, faltaria a Kelevim um testemunho pessoal feito por alguém que tenha a memória de sua própria história pessoal. Faltar-lhe-ia o relato que a faça existir, e não o mero juízo superficial de suas qualidades e defeitos, como é feito no conto (Kelevim seria predominantemente agrícola ou industrializada, tem um sistema judicial invejável etc.). Mesmo sem nenhum dado que relacione, direta ou indiretamente, o conto "Kelevim" ao ensaio "Diário de um candango", a constatação da necessidade de uma literatura produzida em Brasília, assim como o encontro entre o escritor (que é autor, mas não um autor de Brasília) ${ }^{155}$ e o autor de memórias (as quais ainda não são ficção de fato, segundo o ensaio), permitem essa aproximação.

Indo mais além, e seguindo essa linha de força que liga Kelevim a Brasília, Kelevim bem poderia ser uma das cidades imaginadas que Kublai Khan ${ }^{156}$ pede a Marco Polo verificar “se elas realmente existem e se são como eu as imaginei” (Calvino, cap. 3, p. 1) se o conto fosse escrito (pelo narrador); cidade formada de desejos e memórias próprias ligadas a outras cidades. Nomeada, mas não desenhada textualmente, Kelevim evoca imagens incompletas ou

\footnotetext{
${ }^{155}$ Marques é reconhecido como "personagem” de Brasília, mas não um autor da nova capital. No ensaio, Rawet pergunta: “... quando surgirá um autor [sic] de Brasília?; logo em seguida, diz: "O que eu tinha em mãos ainda não era ficção, mas o autor [sic] ali estava presente" (2008, p. 163).

${ }^{156}$ Khan tinha um grande atlas detalhado, com várias classificações: “O atlas do Grande Khan também contém os mapas de terras prometidas visitadas na imaginação mas ainda não descobertas ou fundadas: a Nova Atlântida, Utopia, a Cidade do Sol, Oceana, Tamoé, Harmonia, New-Lanark, Icária” (Calvino, 1990, cap. 9, p. 36).
} 
até mesmo contraditórias que ficam sempre latentes e são condenadas a nunca virem à tona, desde o começo do conto, porque é um projeto abortado em suas duas faces: como conto e como lugar geográfico. Cidade-observatório, seu habitante - ou leitor - acaba por planar no ar, sem nunca tocar o chão, mas também nunca deixando de observá-lo. Aqui, o leitor se vale da cidade (Kelevim) para se observar como leitor, e observar os arredores da cidade (e da leitura), assim como o autor de fato se vale do autor suposto e vice-versa. Kelevim e as Brasílias de Marques e Rawet sobrepõem-se, e como escritor suburbano carioca, o engenheiro Rawet se desloca para Vila Planalto. O curioso é como isso foi feito sem que o "Kelevim" não perca seu status literário de conto/narrativa curta.

\section{9. "Kelevim"}

Região imaginária que, por semelhança nominal com Trebizonda (uma província do nordeste da atual Turquia), o narrador localiza próximo à Armênia, onde "o velho Noé 
foi dar com os costados" depois do Dilúvio, no Monte Ararat. Noé, deve-se lembrar, recebeu de Deus a ordem de salvar a si e aos seus antes do Dilúvio que acabaria com a vida na Terra.

A razão para inventar ao invés de tratar de fatos e lugares reais é prática: preguiça, "porque muito mais difícil é descrever as verdadeiras razões da batalha de Salamina, da Guerra de Secessão ou da cafetinagem histórica que se faz com Auschwitz"157 (Rawet, 2004, p. 205). São acontecimentos históricos com grande quantidade de vítimas, assim como o Dilúvio (guardadas as diferenças entre fatos históricos e mito bíblico).

Mas Kelevim não precisa do artifício "tão barato" de localizá-la geograficamente, diz o narrador. Kelevim surge do nada, em vários aspectos: é produto da imaginação do narrador, é nomeada por associação fonética ao nome "Trebizonda" e à possível proximidade com o monte Ararat. Dá-se a entender que talvez também seja a partir de Kelevim que a humanidade recomece, carregando consigo o passado e os germes do futuro por meio da aliança feita entre Deus e Noé, após o Dilúvio ${ }^{158}$. O conto trata de construir uma cidade e um personagem pelo início de tudo, denotado pela indefinição de ambos. Será visto no final do conto que o Noé kelevista está sozinho e explicitamente abandonado por seu criador. Kelevim já começaria nos moldes da sociedade atual com seus canteiros e avenidas, com a distinção de que "sob o ponto de vista jurídico era [fosse] considerada modelo mesmo pelos vizinhos que a detestavam [...]” (idem, p. 206). Todos os seus habitantes eram orgulhosos de sua condição de kelevistas/Hauches. Kelevim seria a cidade que deu certo.

"Se me fosse necessário localizá-la", "por necessidade infantil", o narrador diz que o faria "ali pela Armênia", onde "pelo que parece", Noé aportou: cidade que "dizem que é tão velha" quanto Noé após o Dilúvio (idem, p. 205). Mas apenas "se fosse necessário". São dados imprecisos que localizariam geograficamente Kelevim, se o narrador se rendesse a esse artifício "repugnante", como ele mesmo diz. Portanto, está claríssimo que Kelevim não existe fisicamente. É ficção destacada do mundo concreto, e o leitor deve levar em conta esse dado constitutivo.

Imaginada, a localização de Kelevim pode ser definida da seguinte forma: é fronteira indefinível entre realidade e imaginação onde surgirá a ficção que dá nome ao

\footnotetext{
${ }^{157}$ Já neste conto, publicado em 1967, Rawet manifesta seu descontentamento com a comunidade judaica e com o uso que se faz da memória oficial da Shoá.

158 "Por causa das águas do dilúvio, entrou Noé na arca, ele com seus filhos, sua mulher e as mulheres de seus filhos" (Gen. 7.7). "entraram para Noé, na arca, de dois em dois, macho e fêmea, como Deus the ordenara" (Gen7.9 . Fonte: http://www.sbb.org.br/interna.asp?areaID=71 . Acesso em: 9/2011.
} 
conto e nomeia a região onde este se passa. "Kelevim não existe. É produto da pura imaginação, chamem-na assim, e da necessidade real de fuga e evasão. Uma espécie de processo de auto-alienação" (Rawet, 2004, p. 205), espaço construído textualmente. O processo de auto-alienação delimita o conto - e com ele a própria Kelevim, o andarilho que irrompe nela e o narrador que imagina - entre os polos formados pelo narrador-autor, de um lado, e Kelevim/andarilho, de outro.

No conto, são as dualidades não-definidas que projetam a estrutura de Kelevim, onde alguém (um homem) vive "um sonho desfeito em sonho", aspirando a "um mínimo de harmonia" (idem, loc. cit.). Foge-se (da realidade) para refugiar-se na imaginação (subjetividade) de um personagem que é tão impreciso e conflituoso quanto a própria Kelevim.

Kelevim é em si um nome gratuito ${ }^{159}$ e lúdico, diz o narrador, que prefere chamar seus habitantes de "Hauches, aspirado" porque "dá margem a uma sugestão de raridade lingüística" (idem, p. 206). Logo após dizer o que não faria, o narrador faz um corte abrupto no texto e começa a imaginar a história de um homem que sente medo e ódio e luta por um sonho que se transforma em pesadelo "que ainda assim se tenta romper com um grito, potenciado apenas e colhido por dentro pela necessidade de dar equilíbrio à tensão". Assim como, logo no início do conto, o narrador diz que Kelevim é produto "da necessidade real de fuga e evasão" (idem, loc. cit., grifo meu), seu personagem tem a necessidade (real) de dar equilíbrio à tensão.

Como em "O logro"160, é um sujeito acuado por sua própria necessidade de expressão e compreensão, bem como suas angústias (fracassos, dúvidas e inseguranças) diante de um mínimo de harmonia desejada: "Tropeça, descamba, alteia em gestos grotescos à simples aspiração a um mínimo de harmonia, ousa aflorar essa capa de indignação com um gesto de recusa, talvez, ou de silêncio" (idem, loc. cit.). Neste ponto, o conto apresenta outro corte brusco e o narrador passa a tratar de Kelevim em seus vários aspectos além da estranheza do nome (é quando denomina Hauches seus habitantes).

Kelevim é descrita por ambivalências, ou seja, pela convivência de movimentos que naturalmente (ou: idealmente?) se excluiriam, formas opostas de organização urbana

\footnotetext{
${ }^{159}$ Soa como o plural de kelev (cão) em hebraico, e mais nada.

${ }^{160}$ In Os sete sonhos (1967).
} 
(“desordem racional e espontânea"), arquitetônica ("glória de ruínas passadas e futuras" "161), econômica ("dividia-se entre agricultura e indústria") e cultural ("havia em Kelevim desde o mais aperfeiçoado cérebro eletrônico que fazia funcionar um grupo de cérebros eletrônicos que por sua vez se sucediam, até alguns costumes ditos bárbaros"; Rawet, 2004, p. 206).

O conto volta-se abruptamente ao homem: "Deu alguns passos e evitou o banco, preferiu o movimento" (idem, p. 207). "Sabia que estava condenado, que estava condenado, que lentamente o despojariam de sua condição mínima": tinha a "nítida sensação de uma idéia a ser contida, controlada, de duas talvez simultâneas a se dilacerarem, ou uma outra a ser reintegrada em seu campo de convenções. Os objetos oscilam entre sólida presença e puro conceito" (idem, loc. cit.) - embora o contorno dos canteiros da avenida kelevista tenha a "consistência de uma definição". Um meio-termo entre "sólida presença" e "puro conceito"? Uma concepção realista de ocupação do espaço, resultado do jogo de forças entre o Desejo e as contingências? Talvez a combinação de ambos, espaço onde se insere o homem (ou: o personagem) e suas idiossincrasias. Enfim, a sugestão de uma metáfora. Ou, mais precisamente, a sugestão de um espaço arquitetado por meio de metáforas.

São "violências linguísticas", esforços de libertar a linguagem dos sentidos cristalizados e que, grosso modo, buscam reviver, recuperando, o $\operatorname{caos}^{162}$ que deu origem à linguagem e, muito posteriormente, à representação mental do espaço. A construção imaginária de um espaço de passagem (a avenida arborizada) por onde um homem imaginário circula e percebe, no contorno dos canteiros (na grama, no "calçamento de alamedas"; idem, p. 207), o "verdadeiro preço de uma afirmação individual, a fruição da dor, como acanalhamento, como covardia, a opção por valores negativos quando os outros bailam no fumo de convenções"163. A progressão da objetividade à subjetividade em uma mesma frase, de "canteiros" a "opção", passando por "afirmação individual”, reforça o entrelaçamento entre personagem e cenário (um determina o outro ao mesmo tempo) que a ficção chamada Kelevim, espaço agrícola e industrial, inevitavelmente cria.

Imprecisões, ambigüidades, oscilações: as imprecisões que sustentam o conto sugerem um lugar indefinido, ou um não-lugar? A imprecisão da possível (e descartada)

\footnotetext{
161 "Glórias de ruínas futuras": consciência de transitoriedade, e também de sucesso (glória) assegurado de ações presentes?

162 Türcke (2010) fala no caos como o que a causa primeira, o "sem-fundo" que motiva a busca pelos sentidos, transformando-se, assim, em "conucópia criativa".

${ }^{163}$ A relação com a dualidade primário/secundário de "Crônica de um vagabundo" é perceptível aqui. Ainda em "Crônica...” o acanalhamento e a covardia são valores humanos.
} 
localização aproximada de Kelevim indica não um lugar, mas um espaço em branco, nãolocalizável. Ou é transição entre real e imaginário, ou se sobrepõe a estes - formando um não-lugar.

A recusa às convenções como valores positivos (contrapondo-se à sua "opção por valores negativos") ${ }^{164}$ manifesta-se como a idéia de um grito, "de um corpo em fuga, em doida corrida $[. .$.$] ". No final do conto descobre-se que a cidade "precisava destruir um$ homem", mas no plano em que existia (o da imaginação). O personagem oscila entre o medo e o ódio. Quem está por trás de Kelevim e do homem, ambos inventados - o homem em aparente desajuste com as condições de Kelevim - é o mesmo que diz que lá "não sou amigo de ninguém"165: "No plano ainda da pura imaginação Kelevim precisava destruir um homem. No mesmo plano este homem teimava em viver para escândalo de todos. E em Kelevim levo uma grande vantagem: não sou amigo de ninguém” (Rawet, 2004, p. 207). Soma-se à estranheza do homem que irrompe em Kelevim, provavelmente o homem a ser destruído, sua opção por pagar o preço da auto-afirmação: “A nítida sensação de uma ideia a ser contida, controlada, de duas talvez simultâneas a se dilacerarem, ou uma outra a ser reintegrada em seu campo de convenções. Os objetos oscilam entre sólida presença e puro conceito. A grama. O calçamento. O contorno dos canteiros adquire a consistência de uma definição" (idem, loc. cit.). Do ponto de vista do leitor, o personagem parece teimar em se fazer existir por meio do que o narrador-autor lhe recusa. Sua identidade é negativa, definindo-se pelo que não é: "o fumo das convenções" que regem Kelevim, contrabalançadas pelos "valores negativos"166 (idem, loc. cit.).

O homem percebe Kelevim pelas suas cores, luz/sombra e sons: "estardalhaço dos pardais", "grito alegre das copas em início de penumbra", "luz intensa [que] varava a folhagem, um azul [que] se justapunha ao verde enegrecido de sombras" (Rawet, 2004, p. 207). Tem-se a impressão de um ambiente com cores e formas bem definidas. Mas talvez

\footnotetext{
164 "Liberdade para" e "liberdade de", respectivamente. O primeiro denota um projeto coletivo e definido; o segundo denota recusa a definir um projeto, e afirmação da liberdade individual. Cf. Jaboby, 2007, p. 108.

${ }^{165}$ Rawet cita Bandeira, indiretamente: o narrador não está em Pasárgada nem é amigo do rei.

${ }^{166}$ Do ponto de vista do personagem, as convenções (i.e., o que ele deveria ser), que coexistem às ambiguidades indefinidas, definiriam seus valores positivos - e, consequentemente, seus traços ficcionais. Do ponto de vista do narrador, a metalinguagem é mais importante do que o personagem, o qual, no entanto, está intimamente ligado a ela. As elipses são muitas, e por isso cada elemento do conto está separado por um abismo transitável.
} 
fosse tudo "fruição momentânea de uma energia sempre renovada, em tensão" (grifo meu). Kelevim, conforme já mencionado, vive em paz com suas ambiguidades, mas a tensão que permeia essas ambiguidades e as relações de seus habitantes com as mesmas - em resumo, a vida suposta do kelevista ou Hauche comum - é de negação das convenções que regem Kelevim em todos os seus aspectos, pode-se dizer. Daí a "fruição de dor" como o "verdadeiro preço de uma afirmação individual" (idem, loc. cit.). Esse homem que aparece em Kelevim "com sua carga de tragédia"167 (idem, p. 205) parece ainda mais isolado, mas consciente do "fumo de convenções" (entendido como inconsistência, abstração e transitoriedade) em que pairam os outros kelevistas. Mas Kelevim e por extensão os kelevistas, não existem.

O criador de Kelevim e deste Hauche (um gauche, pode-se dizer), percebido na figura do narrador do conto, isola-o ainda mais quando diz que não é amigo de ninguém em Kelevim. Nem mesmo do homem resultante de sua imaginação, caracterizando-o subjetivamente, suas percepções, sensações e sentimentos. Se, por um lado, ele isola seu esboço de personagem recusando-lhe empatia e fazendo-o único entre os Hauches, por outro lado valoriza a consciência única e lúcida, embora humanamente instável e insegura, de seu personagem. O leitor é, então, levado a imaginar que tipo seria esse Hauche solitário que não conta com a simpatia de seu próprio criador: alguém que sempre foge e duvida - de si e dos outros. O narrador leva a vantagem de não precisar se aprofundar em questões difíceis como convenções e ambivalências, apenas apontado-as como o fardo do solitário Hauche/gauche.

O lugar-comum do qual se parte, aqui, são precisamente as convenções que sufocam a individualidade, cuja desconstrução exige coragem porque é dolorosa e solitária, mas sinal de lucidez - em Kelevim, ressalte-se, e em nenhum outro lugar imaginado. Ou maldade lúdica por parte do narrador, se não fosse a evocação do texto bíblico que toma Noé a figura central no recomeço da humanidade. Haveria necessidade de ruptura - de um novo recomeço da humanidade, a princípio em escala individual. Haveria: se o narrador cedesse ao "artifício de localizá-la geograficamente" (idem, loc. cit.). Textualmente, no entanto, a cidade está localizada. Mas o artifício do narrador de recusar-se a localizar Kelevim apontando sua possível localização faz o leitor desconfiar da velhacaria do narrador. A credibilidade do narrador já começa abalada pela própria construção inicial do texto. O que permite a seguinte hipótese.

\footnotetext{
${ }^{167}$ Sem a "nostalgia da pureza" não haveria tragédia, diz Rawet em crônica-ensaio sobre Renard Perez (cf. Rawet, 2008, p. 167).
} 
Suponhamos, num exercício de imaginação possível provocado pelo texto, que Kelevim fosse localizada geograficamente: a cidade, imaginada e inventada, tem algo de local bíblico (indicado pela aproximação com Noé e o Monte Ararat) e de cidade moderna (a avenida, "cérebros eletrônicos", o sistema judiciário modelar, a divisão em zona rural e urbana), mas é um local neutro ${ }^{168}$ e virtual (imaginado) em que as ambivalências se encontram, pairando nas órbitas dos referentes bíblico e moderno ao mesmo tempo. Kelevim é um não-lugar cujos significados são retrabalhados e projetados ficcionalmente para fora do conto, em algum (não-)lugar textualmente delineado ${ }^{169}$, entre a recepção do leitor e os significantes que são sustentados pelos enredos $\left(\right.$ plots $\left.^{170}\right)$ sobre os quais o conto se constroi. A cidade constroi-se sobre deduções que podem existir como linhas de força ou como fatos mínimos: a avenida e seus canteiros, a excelência jurídica de Kelevim etc. A possível dualidade antiguidade/modernidade é um dos exemplos possíveis dessa manobra do narrador.

O "lugar inventado" chamado Kelevim, nome que significativamente também dá título ao conto (in Rawet, 2004), mostra-se se, na verdade, um não-lugar; na verdade, uma cidade imaginada pelo narrador-autor que é explorada por um personagem conflituoso e obscuro, e por seu narrador. O narrador vai imaginando a cidade à medida que o personagem avança por Kelevim, de forma que o relato constitui-se num jogo de espaços e intenções expostas logo no primeiro parágrafo; ou é cartografia textual cujas fronteiras nunca são definitivas, em que as dualidades têm função central no emaranhado jogo de significações do texto. Kelevim é um conto cujos alicerces estão à mostra, exigindo que o leitor construa suas paredes segundo as possibilidades ditadas pelo mapa textual esboçado no conto, que dá sinalizações que guiam e delimitam o espaço de ação da imaginação do leitor. "Kelevim" parece expor o mínimo possível de elementos exigidos para se construir um conto. É fruto de imaginação agoniada e dura um átimo, desmanchando-se imediatamente após o leitor começar a interpretar o conto. Mas Kelevim, a cidade, não existe, e portanto o conto é na verdade um "pré-conto", isto é, produto de uma consciência em estado pré-agônico. Percebe-se nesse conto embrionário tomado como conto de fato, o entrelaçamento de conceitos formulados por Rawet em seus ensaios e demonstrados, na prática, nos contos

\footnotetext{
${ }^{168}$ Neutro: nem um nem outro: “lat. neuter, neutra, neutrum, composto de ne 'nem, não' e do adj. e pron. uter, utra, utrum 'qual dos dois, um e outro”. Fonte: Dic. Eletr. Houaiss.

${ }^{169}$ Pode-se falar em "cartografia textual” (Marin, 1973) em que o mapa, que dá nome e torna conhecido um local, apropriando-se dele, transforma-se em relato de viagem ao não-lugar (Utopia).

${ }^{170}$ O termo é usado por Antonio Hohfeldt (1988).
} 
aqui tratados: "Kelevim" é uma ilustração do que Rawet considera "estado pré-agônico" da "problemática da criação", localizado num momento anterior a A hora da estrela de Clarice e de "Crônica de um vagabundo", "Sôbolos rios que vão" e "Reinvenção de Lázaro"; seu personagem pode ser visto como o embrião dos andarilhos dos contos referidos.

A metalinguagem (metaescrita, especificamente) em "Kelevim" é construída pela introdução de questionamentos sob as mais diversas formas - dentre elas, a ausência de informação, ou o excesso de informações imprecisas, ou mesmo a indefinição apontada por dualidades coexistentes em conflito, como se vê em "Kelevim". Em Rawet, a metalinguagem, cujo recurso traz ao texto conotações de prosa poética, dá-se como desestruturação dos referenciais primeiros: as relações convencionais entre significado e significante que basicamente possibilitam o senso comum e o lugar-comum.

O material básico de Rawet é o signo cristalizado, ou seja, o lugar-comum enquanto convenção; o objeto em sua conotação usual; o senso comum do leitor brasileiro que pode compartilhar das vivências do conto.

A partir dessa identificação dá-se início ao processo de desestruturação, pelo questionamento, dos referenciais primários (isto é, a relação utilitária, unívoca e cristalizada pelo uso corrente, entre significado e significante) que constituem o lugar-comum, mais especificamente a convenção e o senso comum. A linguagem convencional é desautomatizada ao longo do conto, em suma: não se sabe ao certo o que é fato e o que é linha de força. O modo como isso ocorre é o que se constitui o conto "Kelevim": uma estrutura frágil e flutuante, feita de partes descaracterizadas ao se separarem do todo do qual faziam parte, ${ }^{171}$ cujas ligações são pensadas, e então feitas de fato pelo leitor ${ }^{172}$. Como já foi dito, o leitor tem papel ativo nos contos de Rawet, característica que se destaca em "Kelevim". A abertura entrevista para "Crônica...", "Sôbolos...” e "Reinvenção...” existe também em relação ao leitor.

"Kelevim" e "Crônica de um vagabundo" constituem um outro (não-)espaço textual, que não se restringe à cartografia textual desenhada pelo relato de um andarilho, mas também revivifica o espaço construído pelo relato, atualizando a experiência daquele que relata e daquele que lê (e se apropria de) o relato como um todo, atualizando a experiência daquele que relata. Enquanto no primeiro conto o espaço surge à medida que o conto

\footnotetext{
${ }^{171}$ Uma ilustração plástica disso é o Merzbau de Kurt Schwitters (1887-1948).

${ }^{172}$ Ao longo do conto e retroativamente, ao final, como dito anteriormente.
} 
progride, no segundo o espaço (urbano) é descrito (caracterizado) à medida que o vagabundo se desloca.

Parece haver zona rural em Kelevim, mas isso é apenas apontado. Ao final, tem-se uma paisagem urbana de uma cidade qualquer ${ }^{173}$ formada por figuras humanas, lugares fechados e ruas escuras: uma cidade descrita a partir da margem, tendo como eixo um forasteiro errante (o vagabundo de "Crônica...") e um andarilho desenraizado (o personagem abandonado pelo próprio autor em "Kelevim") que parece condenado a vagar, a não criar raízes e a ser estrangeiro. Um tipo que encontra formas locais na sociedade (brasileira) e na cultura (de massas): são os marginalizados, grupo que inclui os inconformados e desajustados (“desordem espontânea”), e também os desesperançosos ("glórias de ruínas passadas"), bem como todos os outros errantes indicados indiretamente no texto. Cada signo abre um leque de problematizações se forem lidos como construções a serem desfeitas.

Em "Kelevim", o final do conto é o início do fim do personagem: "No plano ainda da pura imaginação Kelevim precisava destruir um homem. No mesmo plano este homem teimava em viver para escândalo de todos." (Rawet, 2004, p. 207). A objetividade, sinalizada pelo espaço físico de Kelevim, é propositadamente mal-definida pelo narrador, com o propósito de destruir o personagem. Só resta a ele resgatar em si mesmo a pressentida "nostalgia de serenidades inexistentes e de antigas tranquilidades" (idem, p. 205).

O personagem encontra espaços amplos para circulação em que o elemento natural (por oposição a "urbano") é ponto de apoio para o acaso e o lirismo do conto.

De repente o homem apareceu com sua carga de tragédia. [...] Vinha de uma das transversais e sua irrupção na avenida arborizada coincidiu com o estardalhaço dos pardais à maneira de certos instantes do crepúsculo, quando, em meio a um silêncio de

\footnotetext{
${ }^{173}$ A própria não-nomeação da cidade em "Crônica...” concede-lhe o status de cidade imaginada, assim como Kelevim é uma “cidade inventada". Além disso, esse recurso torna-a parecida com o espaço mítico do sertão de Grande sertão: Veredas, em que a caracterização do sertão com cores locais tem seu análogo nos dados da cidade percorrida pelo vagabundo: o porto, a estrada de ferro, o acesso por ônibus, a proximidade da rodoviária com um bar frequentado por prostitutas e marinheiros. Por isso o sertão de Rosa não é inventado, apesar de imaginado. O mesmo se dá com a cidade de "Crônica...”: sua caracterização torna-a imaginada, e não inventada porque, da mesma forma que o sertão roseano, a cor local é um traço peculiar que não exclui a universalidade do que se passa naquele ambiente.
} 
horror irrompe o grito alegre das copas em início de penumbra (Rawet, 2004, p. 206).

O trecho abaixo dá pistas sobre a psicologia do personagem:

Seus olhos moviam-se entre espantados e medrosos como à procura de apoio, e nas contrações do rosto uma transição de medo e insegurança, como se ainda não tivesse conquistado a rigidez do medo autêntico, ou do ódio autêntico (idem, p. 205).

Os termos "apoio", "entre", "transição" indicam passagem entre um estado psicológico e outro: medo e espanto/insegurança. Esse entremeio, cujos polos são o medo e a insegurança ou o espanto, é o análogo subjetivo à objetividade ameaçadora porque maldefinida do espaço textual Kelevim. Percebe-se, então, a fragilidade rigorosa da imprecisão com que o conto (e Kelevim) é construído:

Kelevim sob o ponto de vista de urbanismo participa das duas naturezas: desordem racional e espontânea; sob o ponto de vista arquitetônico já tinha conquistado a glória de ruínas passadas e futuras; sob o ponto econômico dividia-se entre a agricultura e a indústria, embora dissessem alguns que era essencialmente agrícola, e outros essencialmente industrial [...] (idem, p. 206).

A indeterminação tão presente em "Kelevim" força o leitor a se perguntar sobre a relatividade de todas as dualidades, e se as mesmas não são maneiras estabelecidas pelo senso comum de driblar qualquer forma de indeterminação, demonstrando a intolerância pelo que é feito de traços característicos, e não de definições taxativas: Kelevim, uma "cidade" tão urbana quanto rural, segundo dizem, é urbana para os kelevistas que vivem na cidade, e rural para os que vivem no campo, e daí constroem as características de sua comunidade imaginada - ambas chamadas Kelevim: espacialmente, uma só; identitariamente, duas. Mas a brecha para a dualidade abre portas para a pluralidade resultante das combinações entre os vários traços conflitantes de Kelevim. 
Pode-se levar ainda mais adiante a possibilidade factual da localização geográfica de Kelevim: Diante das ressalvas acima mencionadas, a aproximação com o mito bíblico dá a essa cidade inventada um parentesco significativo, pois é região tão velha quanto o Dilúvio, e tem função refundadora, como Noé após o Dilúvio, conforme já foi mencionado. O dado espacial, isto é, a localização possível de Kelevim, sobrepõe-se ao dado temporal, a saber, o tempo imemorável em que Noé viveu e o Dilúvio teve lugar. O intertexto é bíblico, e a história de Noé e o Dilúvio é tomada de empréstimo pelo conto por seus elementos míticos: tempo indeterminado, narrativa de fundação etc. A dualidade faz parte do gênero literário utopia (Marin, 1973): um jogo de cá e lá, referência e referente. A utopia é uma crítica ideológica da ideologia, diz o autor. Daí sua neutralidade como simulacro de síntese, como um terceiro termo de duas proposições contrárias: o que é e o que deveria ser, tese e antítese. Tome-se Kelevim como simulacro de cidade, resultante projetada de forças contrárias que determinam uma cidade, forças essas que formariam conjunturas cambiantes ao longo do tempo ${ }^{174}$. A que tese e antítese essa cidade imaginada se referiria?As dualidades de Kelevim, no modo como são narradas, não conotam diversidade, mas desdém quanto a consensos. Poder-se-ia dizer, então, que não há senso comum em Kelevim ${ }^{175}$. Nesse conto, a lacuna do senso comum, uma das acepções mais comuns de "lugar-comum", é apontada como lacuna da relação com o Outro. Relação que, em conjunto com outras, origina e sustenta o senso comum.

A metaescrita em "Kelevim" (e "Reinvenção de Lázaro") se constrói sobre dualidades insolúveis, estabelecidas pelo texto; estas pairam entre opostos complementares e os atravessam, mas permanecem com a mesma carga contrária, numa existência ao mesmo tempo dependente de cada um dos polos e apenas hipoteticamente independente em si mesma. "Kelevim" é um texto que parte de si, aponta para linhas de força para fora do texto (e mesmo da especificidade do mesmo, o que daria margem para a comparação com o ensaio

\footnotetext{
${ }^{174}$ Considere-se o lugar-comum nos contos aqui enfocados como pequenos mitos, no sentido descrito por Barthes (1993) em Mitologias: O mito moderno é despolitizado, diz o autor, no sentido de que naturaliza a história, tornando-a neutra (ou seja, deformando-a, ao tornar planas suas diferenças). O utopismo manteria a tensão entre forças contrárias (tese e antítese), rejeitando qualquer síntese definitiva e produzindo simulacros fugazes que se sucedem.

175 Juridicamente, Kelevim é modelo de cidade, segundo seus habitantes. Entretanto, esse único consenso não constitui senso comum, já que apenas em relação ao seu sistema jurídico - suas leis - a cidade é exemplar, e não de fato.
} 
"Diário de um candango") e retorna ao mesmo. Percurso engenhoso e tortuoso, sem concessões.

Já "Reinvenção de Lázaro", exercício de metaescrita que difere de "Kelevim”, tem suas dualidades divididas em dois núcleos formados pelas duas partes do conto, claramente diferenciadas por uma quebra no texto, indicada pelo título em itálico. Na primeira, um escritor pensa em como dar cabo de um projeto de conto: "Situação do operário e a intuição de transcendência” (Rawet, 2004, p. 308) é a primeira frase do projeto. Yehuda Bitterman, personagem escritor, pergunta-se como dar vida ao seu personagem, um operário chamado Tião: "Por dentro? Que dentro? Vísceras, veias, artérias, hormônios ossos, nervos? [...] Por fora? A cor da pele? Os movimentos? Os atos entre a esclerose de um hábito e o imperativo de uma ética normativa (pleonasmo)?" (idem, loc. cit.). Perguntas não feitas em "Kelevim", mas provocadas no leitor:

Em “Reinvenção...”, o autor não abandona sua criatura: pelo contrário, transformase nela. O conto será visto adiante, mas algumas diferenças entre essas duas metaescritas, que envolvem a figura do autor, podem ser antecipadas nesse ponto.

Debaixo da "esclerose do hábito" está "o imperativo de uma ética normativa". As perguntas de si para si, feitas por Yehuda, desbastam o hábito esclerosado, conjunto monolítico e sem vida de lugares-comuns sufocantes. A matéria desbastada é parte eliminada e parte transformada, processos intrínsecos entre si. A analogia do ofício de escritor com o de escultor está presente e reflete a estrutura metaescrita do conto. Há, então, uma dinâmica de reciprocidades que distinguem Yehuda de Tião como personagens do conto, mas também deixa claro que Yehuda não criou Tião ex nihilo, mas o inventou como personagem de seu próprio conto. Yehuda inventa Tião, que desvenda os anjos e participa indiretamente do desbastamento dos blocos de mármore.

Assim, um provável judeu que cantou "músicas de negro americano" e emocionou Tião é, na verdade, um judeu de fato (Yehuda) que é capaz de sensibilizar-se com imagens cristãs muito comuns, e dessa forma, por-se no lugar de um operário negro e pobre que contempla seu surgimento.

Era bonita aquela droga, assim de repente. Bonito como daquela vez no meio de um porre com violão em que um tipo gordo e forte, dizem que judeu, sem mais nem menos começou a cantar umas músicas de negro americano. Um troço que sacode a gente por 
dentro, diabo de confusão de choro e tristeza mas que dá vontade de gritar bonito!, (Rawet, 2004, p. 311).

O "momento em que percebe que ele [Yehuda] era Tião" (idem, p. 309) justapõe-se (mas não se distingue) ao momento em que Yehuda era Tião: Yehuda é Tião apenas quando decide escrever sobre ele. Duas formas de uma mesma sensibilidade ideal. A "ética normativa" renova-se, libertando-se dos hábitos esclerosados, e torna-se simplesmente a ética que liga Yehuda a Tião, e é posta em prática por meio da ficção. E ilustrada pelo conto em que essa ficção se insere. Mais uma vez, "eu é um outro". Yehuda deixa de lado suas certezas hesitantes quanto a escrever o conto. O esquema abandonado, diante da história de Tião contada na segunda parte de "Reinvenção...", parece tornar-se paródia dessa mesma segunda parte.

Seu foco é o modo como isso se dá: as convenções. Comparativamente, em "Kelevim", o leitor é apresentado às dualidades, e ao personagem como ponto de confluência das mesmas: as inferências são responsabilidades suas. Essas características dão um tom fortemente poético aos contos de Rawet no sentido de que as possibilidades de ressignificações são vastas, caracterizando a desestabilização do senso comum.

Trata-se de redescobrir, trazer, reinventar, construir desconstruindo, a literatura como uma capacidade - e responsabilidade - humana. O projeto ético-literário de Rawet é claramente problematizante. O leitor fica tão perdido diante de seus próprios parâmetros descritivos quanto o personagem esboçado e logo abandonado à própria sorte. Assim, a estrutura física de Kelevim não fica clara para o leitor (nem para o autor) ${ }^{176}$, a avenida não leva de um lugar a outro, seus habitantes não são individualizados etc.

\footnotetext{
${ }^{176}$ Então, o que procurar em Kelevim? O que, supõe-se, Kelevim deveria ter/ser.
} 


\section{0. "Reinvenção de Lázaro"}

Yehuda Bitterman decide destacar o "episódio de Tião" "de um conjunto complexo para nele exercitar uma série de artifícios" (Rawet, 2004, p. 305) já previstos, num exercício que lhe daria prazer literário:

Numa tentativa desesperada de libertar-se de um sentimento caótico de totalidade Yehuda Bitterman resolveu por fim dar andamento à história de Tião que o atormentava nos últimos tempos. Ou mais corretamente a sua possibilidade de narrar o episódio de Tião que havia destacado de um conjunto complexo para nele exercitar uma série de artifícios.

A princípio, protanto, Yehuda é um escritor e Tião, apenas um personagem em potencial destacado de "um conjunto complexo" de episódios. A visão de dois operários destruindo a golpes e marreta a alvenaria de uma casa velha do outro lado da rua desvia sua atenção. Pensa em sair, "andar um pouco, dar tempo à empregada de fazer a arrumação do quarto, procurar um amigo que morava na esquina da Bento Lisboa"; passa por diversos pontos da cidade e tem a "idéia que poderia ser transformada em história, talvez, de um homem que tem que conquistar dolorosamente, nos mínimos detalhes, todos os episódios que compõem um cotidiano" (idem, p. 307).

Deveria partir do nada, como um homem "que tudo houvesse esquecido": decide que deveria descrevê-lo por dentro. Mas “[q]ue dentro?”, pergunta-se. Ou por fora: mas que fora? $\mathrm{O}$ narrador esbate-se entre auto-questionamentos, dúvidas e incertezas quanto à precisão de palavras e idéias. Passa a pensar no que consiste "dentro" e "fora" quando se pretende descrever a vida de um homem a partir de um novo começo.

À medida que caminha pelas ruas do Rio de Janeiro, pensa nessas questões e nas anotações que fizera. Entre descobertas e reminiscências (uma velha que morde uma maçã, um farol que o ilumina numa caminhada noturna, a cantilena de uma sinagoga), passa por clichês e chega a uma "receita" para a composição de um conto convencional: "Eis um objeto, transforma-o em palavras, precisas, adequadas, de preferência agradáveis, cuidado em não chocar sensibilidades ou valores, controla a imaginação, esconde os andaimes, revela apenas o resultado e ficaremos todos contentes com a oferta e a aceitação do ilusório" (idem, p. 308). 
Os contos de Rawet têm características diametralmente opostas à "receita" do conto convencional: não se preocupam em chocar sensibilidades e muito menos valores; dão azo a voos da imaginação, chegando a confundir as vozes das personagens, usando de fluxo de consciência e discurso indireto livre (recursos narrativos que permitem saltos imaginativos dos quais o leitor faz parte quando participa da lógica desses saltos estruturais do conto); não esconde os andaimes, que muitas vezes são o próprio tema dos contos (como se vê nesta primeira parte de "Reinvenção..."); revela todo o processo e apenas sugere (ou nem isso) o resultado (que é o processo de construção do conto em si); o leitor não se sente apaziguado ao final do conto.

No caminho de volta, passa pela estátua sedestre (sentada) de José de Alencar e “cisma na verdade mais na palavra sedestre do que na estátua [...]” (Rawet, 2004, p. 308). Volta ao quarto já arrumado e ao título do conto Reinvenção de Lázaro. A história deveria sugerir, não explicitar, o que vem nas anotações, indicadas em itálico no texto: "Situação do operário e a intuição de uma transcendência. Aspiração a condições melhores de vida mas ao mesmo tempo aspiração e alguma coisa que não sabia definir e que na [sic] tinha a ver com a condição católica difusa e inconsciente de sua infância" (idem, loc. cit.). O recurso gráfico do itálico também é usado para indicar os movimentos da consciência que guiam as reflexões do narrador, na primeira parte do conto. A tomada de consciência sinalizaria um outro dentro de si, concretizado na narrativa da segunda parte do conto, toda em itálico, : “Como descrever tal homem? Por dentro? Que dentro?"; e mais adiante: "Ou colocá-lo numa perspectiva do futuro, e alimentá-lo com frases do tipo: a mais bela criação do homem é Deus?” (idem, p. 307). A convenção é percebida como aquilo que o paralisava numa "absoluta ignorância": "À medida que a história ia tomando corpo dentro dele, e a personagem ia surgindo difusa, paralisava-o uma absoluta ignorância, consciente dela mesma, do termo que lhe serviria de salvação: convenção" (idem, p. 306). Na segunda parte, o itálico indica a letra de um samba e um trecho da Bíblia.

Às perguntas sobre a estrutura que o conto deveria ter, bem como sobre o ponto de vista adotado (descrição do personagem Tião por dentro ou por fora), soma-se outra: "Quem ou o que era na realidade Tião para ele, Yehuda Biterman?" (idem, p. 308, grifos meus). Às opções "dentro" ou "fora" opõe-se outra: a empatia do narrador para com o personagem Tião e Yehuda lado a lado, em itálico. Essa abordagem preserva a alteridade e recusa toda ilusão partida da identidade convencional entre narrador e personagem - que são, na 
verdade, dois personagens do conto, o que é explicitado quando seus nomes aparecem lado a lado.

Na segunda parte do conto, também intitulado "Reinvenção de Lázaro", o autor dá autonomia a seu narrador, seu alter-ego judeu e literato: o "Judeu Amargo", tradução literal de Yehuda Bitterman. O autor contorna, assim, o pacto inevitável entre leitor e autor de que o que se segue é a história de um personagem, e não um exercício de alteridade literária diletante ("prazerosa") por parte do autor: aqui, Tião é um personagem de Yehuda B., e não do autor, segundo nos diz o conto. Ao atrair para Yehuda a suspeita de ser um alter-ego do autor, sobra a Tião ser o Outro da história (de Yehuda e do autor).

Tião é um trabalhador braçal que descarrega "um bloco de mármore diante do galpão em que se esculpiam imagens para os túmulos do cemitério São João Batista, bem em frente. Volta-se novamente às anotações:

Ajudante de caminhão que transporta blocos de mármore do local onde é extraído até o galpão junto ao cemitério São João Batista onde o bloco é esculpido. Enquanto com os outros ajuda o transporte para o local indicado pelo proprietário observa o trabalho dos escultores. Procurar transmitir todos os sentimentos confusos, de verbalização, a inconsciência de certos problemas que apenas se distinguem da consciência dos mesmos por uma capacidade de racionalização, mas que sob o ponto de vista de solução traz a mesma incerteza e a mesma dúvida do que se ousa considerar como não definitivo" (Rawet, 2004, p. 308).

As indicações finais são bem abstratas, e chamam a atenção do leitor para as soluções literárias que Yehuda dará como resposta às suas anotações. Logo em seguida, Yehuda visualiza reproduções de Velásquez e Miró e reflete sobre suas anotações, extrapolando-as sob a forma de perguntas:

Bestialógico? Pousa os olhos simultaneamente sobre duas reproduções que poderiam estar na parede diante dele: um Velásquez e um Miró. Qual o limite para a desagregação da mente, sem mergulho em nenhum êxtase, mas apenas na dolorosa ausência de nexo próprio? Até que ponto se pode abusar do ponto de interrogação? (idem, loc. cit.). 
Tião é um miserável contrastando com a exuberância das imagens: "é isso mesmo, velhinho, todos vão para lá" (Rawet, 2004, p. 309), diz para si o narrador, sintetizando suas reflexões. Essa simples constatação permite que Yehuda amasse as folhas de anotações e "resolve contar a história de Tião no momento em que percebe que ele era Tião" (idem, p. 309). Era - e não: é, o que eliminaria a alteridade entrevista desde o começo deste conto Tião durante o processo de construção da personagem e, a partir dele, da narrativa. Neste ponto, passa-se à narrativa - um conto dentro do conto.

Tião observa dois escultores descobrindo, cada um uma parte de um anjo. Percebe algumas partes do corpo do anjo surgindo, e se lembra de quando, menino, modelava figuras de barro que nunca ficavam lisas como o anjo que surgia do mármore. Passa então a fazer comparações entre o seu trabalho - "Isso também era trabalho?" - artístico (sambas) e o trabalho dos escultores. Eles deviam ganhar muito dinheiro e seu trabalho durava muito mais do que o de Tião, desperdiçado num cemitério: "Merda, tanta perfeição para um cemitério" (idem, p. 310).

Seus pensamentos oscilam entre o anjo, de um lado, e comparações entre seu trabalho e sua vida, com o trabalho e vida de escultores como aqueles, de outro lado. Tião considera-se um "preto e pobre" conformado (não pacificamente) com a insignificância de seu trabalho diante do trabalho dos escultores, que deviam ser ricos: "Preto e pobre, que se danasse, as coisas estavam certas, e filhos-da-puta já encontrara em toda parte. Rico era rico porque era e estava acabado [...]" (idem, pp. 310-311). Também era "de boa paz, e não queria confusão" como um "amigo de pelada" que se bandeou para os comunistas e acabou "moído pela turma do DOPS" (idem, p. 311). Esse amigo, lembra Tião, "gostara de algumas frases, que a gente tem direito a isso, a aquilo", mas "o cara que apareceu com o falatório deu no pé na hora da porrada" (idem, pp. 311-12). Tião pondera: "Direito dado por quem, se a lei é lei, e quem é que mexe com a lei”. Ao final do conto, não há mudanças na vida de Tião(-Yehuda). Mas diante do leitor, um simples carregador expõe com sensibilidade sua subjetividade e seus conflitos, mostrando-se humanamente capaz, como qualquer homem (e qualquer um de sua condição, conclui-se), de se emocionar com coisas que não parecem ser fáceis de se explicar: a beleza da escultura de anjo, a habilidade dos escultores, as músicas de negro cantadas por um provável judeu ("um troço que sacode a gente por dentro, diabo de confusão de choro e tristeza mas que dá vontade de gritar bonito!”, (idem, p. 311). É a incapacidade de verbalização que Yehuda, o autor da narrativa, propôs transmitir na história 
de Tião. Diante da beleza do anjo e de sua condição de adorno de cemitério, Tião espanta-se: "tudo aquilo feito por um homem que morre, para outro, que já morreu. Feito por um homem!" (Rawet, 2004, p. 312). Tião é um homem com desejos e anseio por compreender o que, por não ser regulado por leis que de alguma forma fazem alguns pobres e outros ricos, é um convite à tentativa de compreensão: a morte.

As intenções de Yehuda B. manifestadas em suas anotações descartadas parecem ter sido cumpridas não como idéias descontextualizadas e abstratas que eram, mas como uma narração que corresponde às observações e simpatias de Yehuda, cuja subjetividade transmuta-se num exercício de simpatia e empatia que mantém a realidade da alteridade Yehuda não é preto, pobre nem operário, deduz-se. Yehuda é Tião por meio da ficção, mas Tião não é Yehuda. Por conseguinte, o leitor é convidado a vivenciar ${ }^{177}$ a alteridade entre Yehuda e Tião, e mesmo a transmutação da subjetividade de Yehuda na subjetividade fictícia (mas nem assim menos real) de Tião. Yehuda parte para uma caminhada casual e acaba transpondo, por meio do exercício literário e movido pela empatia, a distância entre si e o Outro - mas não a elimina, i. e., não elimina a diferença.

$\mathrm{O}$ ato de rasgar as folhas, com anotações ou mesmo em branco, faz Yehuda passar a simplesmente por à prova as dúvidas que tinha quanto à caracterização de Tião (ou seja, vivenciar suas dúvidas e inseguranças), optando pela arriscada (porque não convencional) aproximação por empatia entre narrador e personagem, tentando abarcar o mal-estar psíquico associado ao mal-estar físico de Tião, sua percepção do sublime associada à falta de palavras, e a "moral da história", isto é, a perplexidade que se contrapõe à passividade da mera constatação de que um dia se morre: "Feito por um homem!" (idem, loc. cit.), pensa Tião, em contraste com o superficial e árido "é isso mesmo, velhinho, todos vão para lá" (idem, p. 309) de Yehuda. O lugar-comum trabalhado são as convenções do conto e a

\footnotetext{
${ }^{177}$ No sentido dado por Erfahrung (Buber, Benjamin; cf. Andrade, 2009, pp. 66-67): experiência indireta, mas tão válida quanto a Erlebnis (experiência direta). Toda leitura de ficção é uma possibilidade de Erfahrung. Neste conto, a conservação da alteridade entre Yehuda e Tião, por meio do prólogo do narrador e da quebra em que se insere a narrativa sobre Tião, faz com que a mesma narrativa seja o relato de uma Erlebnis para Yehuda; trata-se da narrativa de sua experiência como Tião, e não simplesmente da vida de um operário chamado Tião - o que cairia numa convenção do conto, por meio do pacto ficcional entre autor e leitor. O conto também seria convencional se, além de Yehuda ser Tião, Tião também fosse Yehuda, estabelecendo movimentos recíprocos, de um para outro (e não de Yehuda para Tião, como acontece no conto).
} 
alteridade como forma de se quebrar essas convenções, pois dessa forma descarta-se a ilusão da camuflagem da individualidade do autor na de seus personagens. 


\section{1. "Sôbolos rios que vão" 178}

Um homem, andarilho da periferia ou louco vagabundo, perambula pelas beiras da cidade, numa região de morros, barrancos e casas pobres. O conto começa localizando o andarilho e esboçando sua índole:

A cidade se desdobrava embaixo num misto de nojo e beleza. Afastou-se do paredão de pedra e terra, atravessou o caminho socado que ladeava o morro e apoiou-se em um tronco à beira do barranco. Fechou os olhos por instantes atordoado pela visão da totalidade, e pelo cansaço. As pernas tremeram ante a súbita ideia de se arremessar no abismo, e um riso histérico sacudiu-lhe o corpo na constatação da própria fraqueza. Era esse então o homem que andava com a morte nos olhos, na boca, no olfato, nos tímpanos, em todos os poros, esse o homem que tinha a morte como lema e meta. Inspirou com violência à procura de calma, e entreabriu as pálpebras já com boa dose de orgulho necessário a seu controle (Rawet, 2004, p. 183).

Tem o hábito de entender literalmente as palavras que lhe são dirigidas: conselhos $^{179}$, xingamentos. Restava-lhe, de "uma vida anterior um resíduo de palavras" que "ainda o fazia sentir o peso de certas situações, e ainda lhe provocava a dor que um ódio não desejado não aplacava” (idem, p. 187).

A dolorosa vida anterior a que se refere é, provavelmente, a vida de antes da loucura: quando as palavras não tinham o peso que têm, de corresponderem exatamente a que o interlocutor entende como intenção. Um "resíduo de palavras [...] lhe provocava dor" e causava um "ódio não desejado" que, no entanto, não aplacava a dor. "E as aspirações eram ainda palavras". Essas aspirações são hiperbólicas: "Eternidade, sonho, glória, instantes de cintilação, saltos de crista em crista de ondas de medo e euforia, a imortalidade das estrelas, os abismos da alma [..]" (idem, loc. cit.); "a última convenção de uma harmonia de palavras".

Há outros estranhamentos, o que faz pensar que são ilustrações dessa aspiração "à última convenção de palavras", uma vez que as aspirações são abstratas e os encontros que

\footnotetext{
${ }^{178}$ O título é o mesmo de um poema de Camões.

${ }^{179}$ O conselho ouvido "quando os primeiros sintomas de idiotice apareceram” foi “- Prostitua-se!”. Faz lembrar o lema do velho de "Crônica..." : “o mundo é um bordel e eu sou uma puta” (idem, p. 224).
} 
provocarão reações estranhas (por algum motivo) do andarilho são experiências relatadas: o alfaiate, o "doador da chave do sucesso e da felisidade [sic]" (Rawet, 2004, p. 186), o policial que se confessa homossexual, após o andarilho perceber suas intenções e fazer o mesmo, arriscando-se "a sofrer uma reação mais violenta" (idem, loc. cit.); o "vulto magro enrolado em um capote", que mal consegue falar e que lembra ao andarilho unicamente sua condição marginal e nada mais ${ }^{180}$; o casal que tem sua carteira vasculhada pelo andarilho, que queima uma pequena parte do dinheiro; a velha prostituta, sem nenhum atrativo, que o aborda e a quem oferece o dinheiro roubado como pagamento para um encontro sexual que a descrição física da velha faz parecer incompreensível.

$$
* * *
$$

$\mathrm{O}$ andarilho tinha sua meta, a morte, definida, e suas experiências rememoradas (e antecipadas). Ele começa sua descida em direção à cidade armado com suas experiências:

A rápida rememoração desses episódios [dos "primeiros sintomas de idiotice"] fez com que desistisse de procurar o alto da montanha, substituto para sua antiga necessidade de deserto e solidão. Seu deserto era a multidão. Por isso retomou o caminho da descida, e trazia em seus passos todos os ímpetos necessários para afrontar a cidade: o choro, a prece, o gesto pornográfico, o golpe mortal, e o ódio suficiente para amá-la [a cidade] em suas transições de ínfimo e sonho (idem, p. 184).

Ínfimo/ sonho é outra dualidade que se põe ao lado de objetivo/subjetivo, terra/céu, pulsão de morte/pulsão de vida ${ }^{181}$ - que perpassam o conto inteiro, como será visto adiante.

\footnotetext{
${ }^{180}$ Não há sequer a empatia sugerida pelas reações para com o casal roubado, o policial e a velha prostituta.

${ }^{181}$ Pulsão como necessidade ôntica (relativa ao objeto) transformada em necessidade ontológica, isto é, “em necessidade de pensamentos que dão apoio e orientação” (Türcke, 2011, p. 133, nota 1). Primariamente, a definição de pulsão, segundo o autor, é a seguinte: "Pulsão vista neurologicamente, é fuga de estímulos: ou, como movimentação externa, fuga diante de estímulos, ou, se estiver disfarçada, como movimentação interna que impulsiona os estímulos à fuga e lhes viabiliza saídas de emergência" (idem, p. 149). Türcke traça uma progressão, em crescendo, que parte da conexão cerebral à representação, buscando as origens do espaço mental, onde se dão a memória e a abstração. A noção de pulsão (Trieb, de treiben: “mover, acionar, impelir, tanger; estimular”) implica, necessariamente, movimento (subjetivo); o que está em foco não é o conceito abstrato "pulsão", mas a "vida pulsional
} 
Assim como, em detalhes metonímicos da realidade objetiva, as cédulas de dinheiro que se retorcem "meio valor, meio cinzas" (Rawet, 2004, p. 188) e a ideia de centro/periferia pensada ao observar os pedaços de galho partido em tamanhos iguais que são lançados numa circunferência traçada na areia.

Olha em redor à procura de uma sugestão de auxílio, mas vê apenas na memória um círculo com alguns pedaços de galho lançados, e vê bem um deles, junto à periferia, isolado dos outro. É então que resolve se afastar, tenso ainda pela persistência de um sentimento mal sufocado.

$[\ldots]$

O homem está em mangas de camisa. Observa-os [um casal] por alguns instantes, e arrisca-se a revolver os bolsos do paletó. [...] De posse da carteira [...] Tira duas notas de mil [...] Acende um fósforo e como quem cumpre um ritual incendeia lentamente as duas notas superpostas. $\mathrm{O}$ papel se recusa no início, mas depois aceita a chama e se retorce meio valor, meio cinzas (idem, loc. cit., grifos meu).

Ao lado das dualidades, as enumerações que percorrem o conto dão pistas para sua interpretação. Mas não solucionam imprecisões. Uma delas é indicada em "ínfimo" e "sonho": O conto não dá a entender de que grupo faz parte "ínfimo" ("transições de ínfimo e sonho"), e de que lado fica "sonho": não parece ser possível separar as dualidades em grupos estanques de valores contrários, positivo e negativo. Por exemplo: "sonho" pode ficar ao lado tanto de terra como de céu, em suas várias denotações. As listas possíveis são várias. Outro tipo de "lista", consistindo de enumerações de decisões, partes do corpo, palavras sublimes e outros termos que formam um grupo não classificável e que tanto precedem decisões quanto sucedem confrontos, são as seguintes:

1) "Por isso retomou o caminho da descida [depois de observar a cidade do alto de uma montanha], e trazia em seus passos todos os ímpetos necessários para afrontar a cidade: o choro, a prece, o gesto pornográfico, o golpe mortal, e o ódio suficiente para amá-la [a cidade] em suas transições de ínfimo e sonho" (p. 184, grifo meu).

específica" (idem, p. 25) da qual o pensamento surgiu, depois de um longo e complexo processo de condensação, deslocamento e inversão, como representação. O nome - a palavra - é representação. 
2) Impressões do confronto com o alfaiate: "a gratuidade da linguagem, o choque com tudo aquilo que está um pouco fora de uma pequena faixa de hábitos, a possibilidade de suportar uma ação grotesca, a impossibilidade de suportar o que parece uma atitude ridícula, o lado elementar de paixões a ditar normas impossíveis de serem seguidas sem uma consequente perturbação" (Rawet, 2004, p. 185).

3) Enquanto acompanha o policial: "Sorriu ao perceber o embaraço do outro, e embora não o assustasse tanto a perspectiva de passar um ou mais dias em uma cela com todas as implicações de um registro, embora não fizesse empenho especial no momento naquilo que os outros chamavam de liberdade, resolveu facilitar as coisas para o outro" (p. 186, grifos meus).

4) Aspirações que "ainda eram palavras": "Eternidade, sonho, glória, instantes de cintilação, saltos de crista em crista de ondas de medo e euforia, a imortalidade das estrelas, os abismos da alma, a última convenção de uma harmonia de palavras" (idem, p. 187).

5) Após a aceitar a prostituta: "O homem observa o corpo magro e anguloso, os seios murchos e pendentes, as coxas marcadas por fibras endurecidas, e renuncia a todos os seus modelos de perfeição e ideal ao deitar-se e apelar apenas para o funcionamento de um organismo desligado de suas ilusões" (idem, p. 189).

6) Após ser atacado, quando saía da casa da prostituta: "Pensou em dizer-lhe que nada mais tinha, pensou em gritar, pensou em que não deveria ter dado tudo à mulher e que agora alguma coisa sobraria para este, pensou também em recuar e tentar a fuga. Mas enfrentou-o" (idem, loc. cit.).

Diante dessas constatações em tom de distanciamento pelo narrador ${ }^{182}$, é certo que as dualidade não são complementares - embora pareçam ser, ao considerar-se opostos entre si os termos "ínfimo" e "sonho" (em relação à cidade). Essa oposição entre um adjetivo com valor nominal e um substantivo abstrato engendra chaves interpretativas (paradigmas) que determinam todos os sentidos do conto. A certa altura, o personagem tem um acesso de fúria contra um homem que o ameaça com uma faca: "Só quando o outro o obrigou com os olhos a encarar a mão na altura do ventre é que viu a faca encaixada entre os dedos. [...]. Mas enfrentou-o. Apelou para sua demência, e com um grito lançou-se sobre o homem” (idem, loc. cit.). Ele consegue se livrar do homem, matando-o. Compreende-se que a demência (loucura) é que o leva a reagir dos modos como reage: roubando apenas uma parte do

\footnotetext{
${ }^{182} \mathrm{O}$ tom distante do narrador visa abster-se de emitir juízos sobre o personagem, de forma a preservar sua subjetividade do personagem, como bem observa Reis (2009, passim).
} 
dinheiro, ajudando o policial a expor seu desejo, pagando a uma prostituta nada atraente, investindo contra o leitor de sonhos, reagindo a um assalto com faca. $\mathrm{O}$ que seriam resquícios de pudor, generosidade e coragem são, na verdade, sinais de loucura e desejo de morte (aos outros a si mesmo), relacionado às ocorrências da palavra "ódio". O que está comumente atribuído à retidão moral é manifestação da loucura do andarilho. Loucura essa movida pelo ódio do personagem. Portanto, a loucura do andarilho não é o que toda loucura parece ser.

Nas necessidades instintivas como sexo e comida ${ }^{183}$ e em sua urgência de satisfação está a felicidade, mesmo que ilusória, expressa no erro ortográfico do "cartaz enorme" que o personagem vê numa barraca, nos arredores do morro onde começa o conto: "CONTE-ME SEUS SONHOS E EU LHE DAREI A CHAVE DO SUCESSO DO FUTURO E DA FELISIDADE [sic]" (idem, p. 185). O andarilho narra ao homem (o "quarentão") o único sonho que possuía: "sentado a uma mesa comia pão. O quarentão explodiu numa gargalhada e o homem se ergueu irritado. Explicou-lhe novamente que no sonho se via sentado a uma mesa e comia pão" (idem, p. 186). Tudo acaba em briga, e aparece o policial que viria a prender o velho.

O sonho sugere claramente a satisfação de necessidades orgânicas, naturais. Como “um cão que vaga à toa" (Rawet, 2004, p. 183): “Uma intensa vibração de ódio e medo levara-o a abandonar as ruas agora ao longe, e procurar o topo da montanha pela estreita faixa que coleava a encosta. Como um cão, um cão que vaga à toa” É necessidade nua e crua, desprovida de interesses camuflados, provocando a desconfiança do homem que lê sonhos - e no leitor que vê um cão que vaga ao lado de um homem que come. A simplicidade aparente desses dois impulsos humanos necessários à subsistência mínima e ao prazer seriam, portanto, inerentes à vida humana (pulsão de vida) - para aquém de um discurso convencional grandioso como manifestação das aspirações mais humanas e abstratas como "[e]ternidade, sonho, glória” etc.: para aquém, portanto, da necessidade travestida de grandiosidade inalcançável e convencionalmente sublime, assepticamente sobreumano. Com isso, a maior manifestação de sanidade é a loucura, a de amor é o ódio, a de ideais são as necessidades humanas mais primárias. Sem que, com isso, uma torne-se a outra, já que, como dualidades não-complementares, um termo não carrega consigo seu

\footnotetext{
${ }^{183}$ Essas necessidades são parte do que Freud (apud Türcke, 2010, passim) chama pulsão de vida (isto é, impulsos instintivos de auto-preservação). Sua manifestação, no entanto, nunca é “pura”, ou seja, nunca é despida de contornos culturais.
} 
oposto. Um homem que come pode, sim, parecer-se com um cão que vaga se isso significar que a inversão dos atributos seja natural: é natural que um cão precise comer e um homem precise se movimentar. Portanto, se um homem não tem o que comer, ele estará subumanizado, dentre outras inferências éticas possíveis.

Ao final do conto, quando o andarilho desce o morro, vê "um barranco que lhe deu de súbito a fusão de um mar enegrecido e de um céu estrelado a lua se impôs com o seu clarão de lenda e superstição" (Rawet, 2004, p. 190, grifo meu). O estranhamento do leitor aumenta com o encontro do andarilho com um homem que, pela descrição e pela sugestão do "clarão de lenda e superstição" da lua faz pensar num lobisomem: "a visão de um homem peludo, de longos cabelos, pupilas imensas de medo, e dois dentes apenas cilíndricos implantados nas gengivas duras". Esse era "um reencontro inadiável”, imaginado: "dos olhos fechados finalmente para um reencontro inadiável” (idem, loc. cit.). Reencontro que remete à infância e seus medos noturnos: "E a prece começava com a expressão de noite, que era a expressão que uma criança há muito tempo usara para lhe contar certas coisas" (idem, loc. cit,).

A lembrança dos medos infantis e o reencontro imaginado com o lobisomem, assim como a fusão da escuridão da noite e do distante céu estrelado liga o telúrico ao cósmico e dá concretude às necessidades do andarilho (dualidade terra/céu). Assim, o que assusta por ser um cão com formas humanas, ou vice-versa, pode ser entendido pelo leitor como um mendigo louco, desairoso e desdentado. E essa ponte se dá no/ por meio do sonho que o conto revela ser: "o sonho de um outro, de um outro homem talvez" (idem, loc. cit.).

Essa afirmação empresta, retroativamente, conotação onírica ao conto todo, e faz pensar nas reações do andarilho a elaboração de desejos recônditos, prescindindo-se assim de informações como identidade do andarilho e motivações objetivas. Subjetividade e objetividade confundem-se por meio de uma errância onírica, sugerida em "Crônica de um vagabundo" e explicitada em "Sôbolos...". A meta desse sonhador/andarilho é a memória, uma vez que as potencialidades de sentido do conto explodem no final, quando se diz que o andarilho (e, por extensão, tudo o que se passou) pode ter sido o sonho de um outro homem. O medo infantil do folclórico lobisomem passa a ser ícone dos medos infantis. E, por extensão, dos medos humanos primordiais que, segundo Türcke (2010), foram os sustos que deram origem à palavra como forma de que, ao tentar se apropriar do inominável, ele se torne minimamente suportável. 
"Há muito tempo", diz o narrador, deram-lhe o conselho de prostituir-se, "antes que os cabelos começassem a embranquecer e antes que a barba pouco espessa lhe contornasse a face" (Rawet, 2004, p. 184). A imagem do cão transforma-se num imperativo: “- Prostitua-se!”, passando pelas reações fisiológicas sexuais: "O orgasmo, a ejaculação, e a tranquilidade do corpo imerso na simples condição de existir” (idem, pp. 183-184). Também o reencontro imaginado ao final do conto dá-se acompanhado por um tremor no corpo,e outras reações físicas, manifestações de um "fome de harmonia"que culminam numa prece:

De um rádio longínquo veio esbatido o som de um regional. E todo seu corpo tremeu numa fome de harmonia. Das pulsações de seu cérebro, do ritmo de sua respiração, das contrações do estômago e do ânus, da consciência de todas as suas vísceras banhadas por um sangue antigo, da lua imóvel na sua órbita celerada, dos olhos fechados finalmente para um reencontro inadiável jorrou uma prece improvisada e a visão de um homem peludo, de longos cabelos, pupilas imensas de medo, e dois dentes cilíndricos implantados nas gengivas duras (idem, p. 190).

O corpo mobiliza-se pelo furor, que é detalhadamente rastreado. A lua e o reencontro imaginado são dimensões desse furor. A loucura não está bem definida, sendo também chamada de idiotice e demência, e se caracteriza pela compreensão literal de tudo que lhe é dito, conforme dito antes. É necessário entender essa loucura mal-definida como a face visível de desejos recônditos, sinalizados pelos impulsos instintivos da fome e do sexo (pulsão de vida) e pela morte como lema e meta (pulsão de morte ${ }^{184}$ ). Neste caso, quais são esses desejos?

Obviamente, não é possível uma investigação biográfica do andarilho, caracterizado com poucos traços. Dada a especificidade do conto, que evoca os mecanismos

\footnotetext{
${ }^{184}$ Ambas as pulsões conforme descritas por Christoph Türcke em Filosofia do sonho. Pulsão de morte como cessação dos estímulos externos que desequilibram as representações criadas no campo mental para atender à demanda irrealizável da satisfação plena do desejo. A aspiração a essa realização, no entanto, não deixa de ser real e atuante no mundo. Sua realização só seria possível num espaço utópico e idealizado pelas camadas de sentido que as palavras arrastam consigo desde que passaram da nomeação do "susto" primordial à representação mental da satisfação plena do desejo. Dessa forma, a insatisfação, ou seja, a incompletude é o que move o sujeito no mundo. Cf. Türcke, 2010. Nesse sentido, o encontro com o Outro é o fator desestabilizador desse consumir-se no próprio ego, entropia destrutiva.
} 
de um sonho, a pergunta pode ser reformulada: Como se dá, aqui, a relação entre desejos recônditos e o corpo, local do encontro entre vida e morte, e ponto de convergência dessas que são as duas realidades e pulsões básicas do ser humano, consideráveis duas formas de se ver a dinâmica de suas vontades?

Sabe-se que o andarilho "respondia com todo o corpo às perguntas que exigiam apenas palavras": "O orgasmo, a ejaculação, e a tranquilidade do corpo imerso na simples condição de existir" (Rawet, 2004, pp. 183-184). O corpo e suas explosões de sensibilidade opõem-se às palavras e suas harmonias convencionais: a oposição corpo/palavra tem dimensões cósmicas ao justapor-se, no final do conto, à lua e ao barranco "A meio caminho, [de subir a montanha] quando um barranco lhe deu de súbito a fusão de um mar enegrecido e de um céu estrelado e de um céu estrelado a lua se impôs com seu clarão de lenda e superstição" (idem, p. 190), e mais uma vez subjetividade e objetividade se confundem num contínuo. Mais propriamente, a subjetividade constrói a objetividade, ao mesmo tempo em que esta determina aquela. Isso reforça o caráter onírico do conto.

O conto termina da seguinte forma: "E no canto de uma calçada, junto a um edifício em construção, deitou-se. Precisava dormir. Tinha sono. E só antes de adormecer, já com as pálpebras quase juntas percebeu que ele era o sonho de um outro, de um outro homem talvez" (idem, loc. cit.). A errância onírica do andarilho termina ao lado de um prédio em construção (um prédio não finalizado, portanto) - imagem significativa para um conto permeado de questionamentos e signos que denotam afastamento e obscuridade: a noite, o morro à beira da rua, o caminho tortuoso até a casa de madeira da prostituta.

A "última convenção de uma harmonia de palavras" (idem, p. 187) é a convenção das aspirações humanas: sublimes sempre, mesmo as mais instintivas, que convencionalmente são minimizadas e cobertas pelo manto protetor das convenções sociais (equivocadamente) - nunca como, de fato, necessidades básicas cuja manifestação de alguma forma poderia conspurcar os ideais humanos grandiosos, generalizantes e assepticamente destacados da vida, que o personagem vive e põe à prova.

O andar a esmo desse andarilho louco é indicado logo de início pelo título do conto, que usa um arcaísmo: "Sôbolos [sobre os] rios que vão". Mais uma vez, como nos outros contos analisados, o leitor é participante dos sentidos produzidos pelo conto, a começar pelo título. A interpretação do título do conto e as imagens sugeridas pelo texto incitam o leitor a glosar o título para conseguir compreendê-lo à luz do conto, estendendo, de certa forma, o 
reencontro: sôbolos rios que vão para o mar enegrecido da noite, aos pés do andarilho onírico, a cidade "misto de beleza e nojo" (Rawet, 2004, p. 183) etc.

Além disso, cada palavra tem um peso enorme para o conto todo, o que não se atenua sequer nos momentos de humor, como quando o andarilho recebe "duas bananas ${ }^{185}$ ", ao entrar na feira ("Estendeu a mão diante de uma dela [uma das barracas] e recebeu duas bananas", idem, p. 185). Isso faz com que o narrador tenha uma função central na narrativa ao "escolher" as palavras adequadas. Dessa forma, a subjetividade do andarilho confunde-se com o narrador. A estranheza de seus atos e a imprecisão de suas motivações levam o leitor para dentro dessa errância por meio da palavra e seus sentidos.

${ }^{185}$ Isto é, uma fruta e um gesto rude. 


\section{Conclusão}

A obra de Samuel Rawet tem características peculiares que se mostram com a necessidade de se definir as formas de abordar a figura do andarilho. A definição do lugarcomum rawetiano, nos contos analisados, demanda intensa participação do leitor, que se vê às voltas com questões sobre identidade (brasileira, judaica) e expressão (gênese literária e figuras de linguagem), em especial a metáfora - questões sintetizadas em "Kelevim" e trabalhadas especialmente em "Crônica de um vagabundo". Assim, este trabalho se viu às voltas com a necessidade de deixar claros conceitos como metáfora, errância e suas implicações (Judeu Errante e identidade) em Rawet, baseando-se nos próprios contos selecionados a partir de uma definição geral de lugar-comum rawetiano, como esclarecido anteriormente (cf. cap. 2).

As análises partiram de leituras cerradas dos contos, sobre as quais se ergueram pressupostos para a abordagem dos contos. O confronto desses pressupostos com as expectativas do leitor guiaram e construíram as análises, mimetizando, do prisma possível graças à visão panorâmica de leitura que caracteriza o lugar do leitor frente à obra literária, as errâncias dos andarilhos. Tal mimetização foi a forma naturalmente encontrada para imiscuir-me no texto rawetiano e, coerente com as linhas de força e a dinâmica de sentidos dos contos, perder-se neles.

Assim, este trabalho acabou por encontrar na peculiaridade literária de Samuel Rawet seu foco principal, a partir do conceito de lugar-comum. Diante da dinâmica de renegociações de sentidos que tiveram como eixo os andarilhos, a necessidade de encontrar formas eficientes de se abordar o texto se mostrou premente.

Como consequência, esta tese foi estruturada como um labirinto de tentativas de aproximação ao texto rawetiano, mais do que um conjunto de análises propriamente ditas (com começo, meio e fim). Como um Merzbau ${ }^{186}$, os caminhos errados (em suas várias acepções) também estão presentes à sombra do texto (como Ahasverus, e questões sobre identidade e a noção de literatura judaica), ou visíveis e integrados funcionalmente à discussão (a figura do autor efetivo, biografia). Todas essas formas de abordagem aos contos de andarilhos passam pelo lugar-comum em Rawet, em que os refugos e resíduos, semelhantemente aos Merzbauten de Kurt Schwitters, são tão importantes quanto o objeto, uma vez que são feitos do mesmo material: a palavra.

\footnotetext{
${ }^{186}$ Cf. Anexo 1, Figura 2.
} 
Dos Merzbauten de Schwitters só restam fotos, pois foram destruídos, mas são imitados, tendo assim continuidades virtuais. Eram construções intermináveis e aleatórias, formando grutas que aceitavam objetos distintos, e que poderiam ser encobertas durante o processo de crescimento simultâneo em diversos pontos, do Merzbau.

Como analogia, os contos analisados projetam-se virtualmente, em linhas de força, para fora dos contos, principalmente "Kelevim". Dentre esses "Merzbauten textuais", "Kelevim" liga as linhas de força dos outros contos: trata da figura do andarilho (correspondente, distante da figura do Judeu Errante laicizado), da criação literária, da linguagem por meio da qual se oscila entre conceito e objeto, referência e referente ("Os objetos oscilam entre sólida presença e puro conceito", Rawet, 2004, p. 267).

Em "Kelevim", os opostos (complementares ou não) convivem em tensão permanente, característica marcante nos contos de Rawet. Os fios que costuram internamente os contos são formados pela relação indivíduo-palavra e seus desdobramentos, e pelas reflexões ativas presentes nos contos - ou seja, constroi-se e desconstroi-se, alternada e sucessivamente, em hipóteses explicativas ou caracterizações que logo em seguida são relativizadas ou desmentidas, à medida que se caminha - , seja pela voz do narrador, seja pela voz do personagem.

A linguagem com que o andarilho descreve sua errância torna-se, como expressão subjetiva desse laço frágil que marca a condição do exílio interior, o único referencial espaço-temporal do sujeito desenraizado. Consequências disso são: o narrador que se desdobra em autor projetado para fora do texto e narrador, introjetado no texto de "A reinvenção...”; a figura-síntese do andarilho, que remete à figura do Judeu Errante, em "Crônica..." e indiretamente em "Kelevim".

$\mathrm{O}$ andarilho é, a princípio, aquele que constrói seu mundo à medida que caminha, destruindo-o e reconstruindo-o conforme conquista seu caminho, com o único meio de que dispõe: seu corpo. Sua identidade nunca tem contornos definidos, sendo apenas sinalizada por objetos (a máquina de escrever portátil na mala do vagabundo de "Crônica...") e pelas relações contingentes do personagem com o mundo a sua volta (Tião e o trabalho que impõe limites a sua subjetividade; os andarilhos de "Sôbolos..." e "Crônica...", que se deixam surpreender com estímulos vindos do meio urbano e de seus habitantes, sem que tenham expectativas definidas quanto a suas andanças sem rumo).

Assim, até mesmo o fazer literário - e, por extensão, a aura de intelectualidade auto-suficiente do escritor -, é questionado por meio do questionamento das convenções do 
conto. O enredo é implodido (cf. Santos, 2008, p. 21) e a subjetividade - verdadeiros cacos de subjetividade - confunde-se com a objetividade, tendo suas fronteiras borradas ou emaranhadas ${ }^{187}$, levando adiante a interiorização da narrativa já presente em autores da geração anterior.

Em resumo, a íntima relação entre objetividade e subjetividade em Rawet faz com que seus personagens sejam indivíduos (ou apenas projetos de personagens) intrinsecamente errantes, cujo ápice é o exercício minuciosamente detalhado de empatia feito em "Reinvenção...". Sejam eles narradores solidamente marcados, vagabundos ou projetos de personagens, erram pela palavra. O narrador de "Reinvenção..." se vale da experiência das suas próprias deficiências de expressão de si e do meio, como necessidades vitais, para buscar a melhor forma de contar a história de Tião, em busca da mais acurada forma de expressão. Assim, o projeto para um conto sobre "A situação do operário e a intuição de uma transcendência" (Rawet, 2004, p. 308) não é suficiente para a escrita da história do operário que já tem um nome: Tião. Foi necessário criar o projeto, refletir sobre ele para descartá-lo como estrutura pré-elaborada e perceber "que ele era Tião" (idem, p. 309). A história partiu da depuração do projeto ao longo de seus devaneios pelas ruas do Rio de Janeiro, processo que acabou por desgastar tanto o projeto que ele teve de ser descartado por estar superado. A posição confortável do escritor e seu projeto cede lugar à "poesia da aflição" ("poetry of distress"188) incômoda e cativante que é a história de Tião-Yehuda.

Em "Reinvenção...", o narrador se vale de um paradoxo para iniciar sua história: "resolve contar a história de Tião" no mesmo momento em que toma consciência de "que ele era Tião", numa progressão que vai do operário genérico do projeto de história, no início do conto, à experiência de identificação, pelo exercício literário, com esse operário que passa então a existir. A partir da constatação da impossibilidade de uma representação correta e definitiva, surge a possibilidade, reconhecidamente falha (e por isso mesmo mais

\footnotetext{
${ }^{187}$ A função do autor também entra nesse questionamento, podendo-se falar em "mobilidade das interfaces de autobiografia [do próprio Rawet] e grafia do real, com a concretização de uma mímesis do mundo”, segundo Santos (2004, p. 35). A mímesis de que fala o crítico seria a mímesis literária da condição judaica absolutamente própria do escritor Samuel Rawet, embora possam ser entrevistas características que o aproximem de outros escritores, judeus ou não. Ao falar-se em "mobilidade das interfaces de autobiografia e grafia do real" evita-se tomar Rawet como um "representante do judaísmo genérico", o que seria uma leitura superficial tanto dos traços judaicos ou modernos de sua escrita, como um autobiografismo extremamente limitador.

${ }^{188}$ A expressão é tirada de Miron, D. in Wirth-Nesher, 1994, p. 103.
} 
livre de exigências extraliterárias), da identificação fictícia: Yehuda era Tião. Da mesma forma, se em Contos do imigrante "não há sabedoria a ser transmitida aos ouvintes, sendo inexistente o interesse destes em se constituir como alguma espécie de audiência frente àqueles que narram"189 (Chiarelli, 2007, p. 44), em Os sete sonhos há transmissão da impossibilidade de diálogo, ou seja, de experiências embrionárias abortadas que geram uma outra forma de sabedoria pelo diálogo com outro tipo de audiência: aquela formada pelos leitores. Para tanto, são mobilizados "conselhos, provérbios, ditados e outras formas exemplares de transmissão da sabedoria prática" (idem, p. 55), entendidos aqui como características dos lugares-comuns rawetianos. Nesse sentido, uma nova forma de memória coletiva $^{190}$ - não mais épica, consensual e fundadora, mas prosaica e negociável - surge no texto.

A palavra em seu uso como linguagem convencional, no entanto, paira como um duplo (ou fantasma) sobre a linguagem construída a partir das estruturas daquela: é reconhecendo e explorando as deficiências que essa nova linguagem é, por meio do uso da palavra ${ }^{191}$, continuamente analisada e esmiuçada na forma de contos metalinguísticos ("Kelevim”, "Reinvenção...) e sintetizada na figura do vagabundo/andarilho e suas andanças (“Crônica....; "Sôbolos...”; “Kelevim”; "Reinvenção...”).

\footnotetext{
${ }^{189}$ Vide "O profeta", em Contos... .

${ }^{190}$ Uma forma paródica, porque preserva seu referente.

${ }^{191}$ Isto é, metalinguisticamente.
} 


\section{Referências bibliográficas}

\subsection{Corpus analisado ${ }^{192}$}

RAWET, S. "O profeta". [1956]. In Contos e novelas reunidos. Rio de Janeiro: Civilização brasileira, 2004. Org. André Seffrin.

. “Diálogo". [1956]. In RAWET, S. Contos e novelas reunidos. Rio de Janeiro: Civilização brasileira, 2004. Org. André Seffrin.

"Fé de ofício". [1967]. In RAWET, S. Contos e novelas reunidos. Rio de Janeiro: Civilização brasileira, 2004. Org. André Seffrin.

. "Sôbolos rios que vão". [1967]. In RAWET, S. Contos e novelas reunidos. Rio de Janeiro: Civilização brasileira, 2004. Org. André Seffrin.

. "O logro". [1967]. In RAWET, S. Contos e novelas reunidos. Rio de Janeiro:

Civilização brasileira, 2004. Org. André Seffrin.

"Kelevim". [1967]. In RAWET, S. Contos e novelas reunidos. Rio de Janeiro:

Civilização brasileira, 2004. Org. André Seffrin.

. "Crônica de um vagabundo". [1967]. In RAWET, S. Contos e novelas reunidos. Rio de Janeiro: Civilização brasileira, 2004. Org. André Seffrin.

. "O terreno de uma polegada quadrada". [1969]. In RAWET, S. Contos e novelas reunidos. Rio de Janeiro: Civilização brasileira, 2004. Org. André Seffrin.

"Reinvenção de Lázaro". [1969]. In RAWET, S. Contos e novelas reunidos. Rio de Janeiro: Civilização brasileira, 2004. Org. André Seffrin.

. "A lenda do abacate". [1981]. In RAWET, S. Contos e novelas reunidos. Rio de Janeiro: Civilização brasileira, 2004. Org. André Seffrin.

. “O casamento de Bluma Schwartz". [1981]. In RAWET, S. Contos e novelas reunidos. Rio de Janeiro: Civilização brasileira, 2004. Org. André Seffrin.

“'BRRKZNG: pronúncia - bah!”. [1981]. In RAWET, S. Contos e novelas reunidos. Rio de Janeiro: Civilização brasileira, 2004. Org. André Seffrin.

RAWET, S. "Diário de um candango". [1963]. In Ensaios reunidos. Rio de Janeiro: Civilização brasileira, 2008. Orgs. Rosana K. Bines e José L. Tonus.

\footnotetext{
192 Os contos estão dispostos na ordem em que aparecem no volume.
} 
. “Começo de caminho: o áspero amor (Renard Perez)" [1967]. In Ensaios reunidos. Rio de Janeiro: Civilização brasileira, 2008. Orgs. Rosana K. Bines e José L. Tonus.

. “Chão galego - A dupla viagem de Renard Perez". [1972]. In Ensaios reunidos. Rio de Janeiro: Civilização brasileira, 2008. Orgs. Rosana K. Bines e José L. Tonus.

- "A Hora da Estrela ou as frutas do Frota, ou um ensaio de crítica literária policial. [1979]. Ensaios reunidos. Rio de Janeiro: Civilização brasileira, 2008. Orgs. Rosana K. Bines e José L. Tonus.

. “Irmãos da Noite do irmão da noite Renard Perez" [Inédito, escrito após 1979]. In Ensaios reunidos. Rio de Janeiro: Civilização brasileira, 2008. Orgs. Rosana K. Bines e José L. Tonus.

\subsection{Bibliografia consultada}

ANDRADE, L. A. Almas em fogo: As Histórias do Rabi sob o pensamento de Martin Buber. 128f. Dissertação - Mestrado em teoria e história literária. Campinas: Programa de pós-graduação em teoria e história literária, Depto. de teoria literária, Instituto de estudos da linguagem, Unicamp, 2009.

ANDERSON, B. Comunidades imaginadas. São Paulo: Cia. das letras, 2009. Trad. Denise Bottman.

ANTUNES, G. A escrita errante em Samuel Rawet. 97f. Dissertação - Mestrado em literatura. Brasília: Programa de pós-graduação em literatura, Depto. de teoria literária e literaturas, UnB, 2011.

AUGÉ, M. Não-lugares: Introdução a uma antropologia da supermodernidade. Campinas: Papirus, 2008. Trad. Maria Lúcia Pereira.

AUSTER, P. Oracle night. [livro eletrônico]. London: Faber and Faber, 2012.

AUSUBEL, N. Conhecimento judaico I. Rio de Janeiro: Sefer; A. Koogan editor, 1989.

Trad. Eva S. Jurkiewicz. (Judaica, vol. V).

ÁZARA, M. M. F. Nomadismos: "Crônica de um vagabundo", de Samuel Rawet e Alice nas cidades, de Wim Wenders: errantes urbanos. 89f. Dissertação - Mestrado em letras: teoria literária. Belo Horizonte: Programa de pós-graduação em letras, Depto. de estudos literários, Faculdade de letras, UFMG, 2010. 
BARTHES, R. Mitologias. Rio de Janeiro: Editora Bertrand Brasil,1993. Trad. Léa Novaes. O grau zero da escrita. Seguido de novos ensaios críticos. São Paulo: Martins Fontes, 2004. (Coleção Roland Barthes).

BERRIEL, C. et al. Proposta de criação do U-TOPOS - Centro de Estudos sobre Utopia, Iel, Unicamp, 2008.

BRAGA, T. As lendas christãs [livro digitalizado]. Porto: Casa editora Luga \& Genelioux, 1892.

BROMBERT, V. Em louvor de anti-herois. São Paulo: Ateliê editorial, 2002. Trad. José L. de Lôbo. (Crítica hoje II).

CALVINO, I. As cidades invisíveis [livro eletrônico]. São Paulo: Cia. das letras, 1990. Trad. Diogo Mainardi.

CAMPANElla, T. Cidade do sol. São Paulo: Abril, 1973. Trad. José A. Lôbo. (Os pensadores, vol. XII).

CERTEAU, M. A invenção do cotidiano: Artes de fazer (vol. 1). Petrópolis: Vozes, 1994. Trad. Ephraim F. Alves.

CHIARELLI, S. Vidas em trânsito: As ficções de Samuel Rawet e Milton Hatoum. São Paulo: Annablume, 2007.

COELHO, E. C. Olhares imigrantes: Literatura judaica no Brasil. Dissertação - Mestrado em letras: Estudos literários. 115f. Belo Horizonte: Programa de pós-graduação em letras, Depto. de estudos literários, Faculdade de letras, UFMG, 2008.

CORTÁZAR, J. Valise de cronópio. São Paulo: Perspectiva, 2011. Trad. D. Arrigucci Jr. E J. A. Barbosa. (Debates, 104).

COSTA, F. M. DA. Os subúrbios da criação. São Paulo: Polis, 1979. (Col. Estética 4).

DALCASTAGNÈ, R. Literatura brasileira contemporânea: um território contestado. Rio de Janeiro: Ed. Uerj/Horizonte, 2012.

DERRIDA, J. A escritura e a diferença. São Paulo: Perspectiva, 1995. Trad. Maria Beatriz M. N. da Silva.

ENGELLAUM, P. Samuel Rawet - A alma que sangra. Tese - doutorado em teoria literária. Rio de Janeiro: Programa de pós-graduação em ciência da literatura, Faculdade de letras, UFRJ, 2006.

ERASMO de Roterdã. Elogio da loucura. São Paulo: Abril, 1972. Trad. Paulo M. Oliveira. (Os pensadores, vol. $\mathrm{X}$ ). 
FARACO, S. (org.) Horácio Quiroga: Decálogo do perfeito contista. São Leopoldo: Ed. Unisinos, 1999.

FERREIRA, J. P. “O judeu errante: a materialidade da lenda”. Revista Olhar n. 3, ano 2, pp. 1-7. São Carlos: UFSCar, junho/2000.

FINKELSTEIN, N. G. A indústria do holocausto. Rio de Janeiro: Record, 2001 São Paulo. Trad. Vera Gertel.

FLUSSER, V. Língua e realidade. I. São Paulo: Annablume, 2011a. (Biblioteca flusseriana vol. I).

A história do diabo. 2011b. (Biblioteca flusseriana, vol. II).

Universo das imagens técnicas: O elogio da superficialidade. 2011c. (Biblioteca flusseriana, vol. III). A escrita: Há futuro para a escrita? 2011d. (Biblioteca flusseriana, vol IV). . Bodenlos: Uma autobiografia filosófica. 2011e. (Biblioteca flusseriana vol.V).

GROS, F. Marcher, une philosophie. Paris: Carnetsnord, 2009.

HOHFELDT, A. Conto brasileiro contemporâneo. Porto Alegre: Mercado Aberto, 1988.

JACOBY, R. Imagem imperfeita: Pensamento utópico para uma época antiutópica. Rio de Janeiro: Civilização brasileira, 2007. Trad. Carolina de M. B. Araújo.

KIRSCHBAUM, S.: “Samuel Rawet, ética e literatura”. Vértices n. 4, pp.199-228. São Paulo: Humanitas, 2003,

. "Entre o discurso literário e o discurso filosófico: Samuel Rawet e Emmanuel Lévinas”. Vértices n. 5, pp. 137-144. São Paulo: Humanitas, 2004a .

Ética e literatura na obra de Samuel Rawet. Tese - Doutorado em Letras. 167 f.

São Paulo: Departamento de letras orientais, FFLCH, USP, 2004b. . (org.) Dez ensaios sobre Samuel Rawet. Brasília: LGE, 2007. . "As muitas faces da identidade judaica na obra de Samuel Rawet". Cadernos de língua e literatura hebraica n. 8, pp. 33-50. São Paulo: FFLCH-USP, 2010, . Viagens de um caminhante solitário: Ética e estética na obra de Samuel Rawet. São Paulo: Humanitas/Fapesp, 2011. (Col. Judaica).

KLIDZIO, N. Itinerário urbano na vida e obra de Samuel Rawet. Passo Fundo: Editora UPF/CNPq, 2010.

KRISINSKI, W. Dialéticas da transgressão: O novo e o moderno na literatura do século XX. São Paulo: Perspectiva, 2007. Trad. Ignacio A. Neis, Michel Peterson, Ricardo I. Canko. (Estudos, 242). 
LABARTHE, P. Petits poèmes en prose de Charles Baudelaire. Paris: Gallimard, 2000. (Foliothèque 86).

LAGERKVIST, P. A morte de Ahasverus. Porto Alegre: Globo, 1964. Trad. Milton Amado.

LÉVINAS, E. Entre nós: Ensaios sobre a alteridade. Petrópolis: Vozes, 1997. Trad. Pergentino S. Pivatto.

LILENBAUM, P. C. Judeus escritos no Brasil: Samuel Rawet, Moacyr Scliar e Cíntia Moscovitch. Tese - Doutorado em letras. Rio de Janeiro: Programa de pós-graduação em letras, PUC-RJ, 2009.

LINS DO REGO, J. .Banguê. Rio de Janeiro: Nova Fronteira, 1984a. . Moleque Ricardo. Rio de Janeiro: Nova Fronteira, 1984b. . Doidinho. Rio de Janeiro: José Olympio, 1989a . Usina. Rio de Janeiro: José Olympio, 1989 b. . Menino de engenho. Rio de Janeiro: José Olympio, 2006.

MACHADO DE ASSIS. "Viver". In Várias histórias, 1896. Disponível em: http://machado.mec.gov.br/images/stories/pdf/contos/macn005.pdf . Acesso em: 3/2013. MARIN, L. Utopiques: Jeux d'espaces. Paris: Éditions de Minuit, 1973. (Collection critiques).

MAISTRE, X. de. Viagens ao redor do meu quarto; Expedição noturna ao redor do meu quarto. Porto Alegre: Mercado Aberto, 1998. Trad. Armindo Trevisan.

MARQUES DA SILVA, J. Diário de um candango. Rio de Janeiro: edições "O Cruzeiro", 1963.

MORE, T. Utopia. London: Penguin books, 2009. Trad. Paul Turner.

NAZARIO, L; NASCIMENTO, L. (orgs.). Os fazedores de golems. Belo Horizonte: Fale/UFMG, 2004.

PEREZ, R. Chão galego. Rio de Janeiro: Civ. Brasileira, 1972. Irmãos da noite. Rio de Janeiro: Civ. Brasileira, 1979. (Col. Vera Cruz, lit. brasileira, vol. 276).

RAMOS, R. Graciliano Ramos: Retrato fragmentado. São Paulo: Globo, 2011.

REIS, L. C. M. Deslocamentos e temporalidades. O contato possível em Samuel Rawet 193f. Tese - doutorado em literatura. Brasília: Programa de pós-graduação em literatura, Depto. de teoria literária e literaturas, Instituto de letras, UnB, 2009. 
RESTREPO, L. Herois demais. [livro eletrônico]. São Paulo: Cia. das letras, 2009. Trad. Ernani Ssó.

RICOEUR, P. A metáfora viva. Porto: Rés, s.d. Trad. J. T. Costa e A. M. Magalhães.

RODRIGUES, N. “Onde estão os negros?” In: O óbvio ululante: primeiras confissões e crônicas. São Paulo: Cia. das letras, 2000. Seleção de R. Castro.

ROTH, P. Complexo de Portnoy. São Paulo: Edibolso, 1976. Trad. Cezar Tozzi.

ROUDINESCO, E.; PLON, M. Dicionário de psicanálise [livro eletrônico]. Rio de Janeiro: Zahar, 1998. Trad. V. Ribeiro e L. Magalhães.

SAID, E. W. Orientalismo: O Oriente como invenção do Ocidente. São Paulo: Cia. das letras, 2010. Trad. Rosaura Eichenberg. (Cia. de bolso).

SANTANA JÚNIOR, F. O. "A lenda cristã do mito do judeu errante, sua desconstrução judaica e sua recriação estética na novela de Samuel Rawet”. In: Silel - XIII Simpósio Nacional de Letras e Linguística - III Simpósio Internacional de Letras e Linguística, 2011, Uberlândia. Anais do Silel. Uberlândia: Instituto de Letras e Linguística, 2011, v. 2, pp. 01-17.

SANTOS, F. V. Subjetividades da ficção brasileira contemporânea. Rio de Janeiro: Europa, 2004. (org.) Samuel Rawet. Fortuna crítica em jornais e revistas. Caetés: Rio de Janeiro, 2008.

SARTRE, J. P. A questão judaica. São Paulo: Ática, 1995. (Ponto de vista).

SOCIEDADE BÍBLICA DO BRASIL (SBB). Almeida Revista e Corrigida Online. Disponível em: http://www.sbb.org.br . Acesso em: 3/2013.

TÜRCKE. C. Filosofia do sonho. Ijuí: Editora Unijuí, 2010. Trad. Paulo R. Schneider.

V. A. Kurt Schwitters 1887/1948: O artista MERZ. São Paulo: Kurt und Ernst Schwitters Foundation, 2007.

VIEIRA, N. (org.). Construindo a imagem do judeu. Algumas abordagens teóricas. Rio de Janeiro: Imago, 1994. Trad. A. Lissovsky e E. Lissovsky.

Jewish voices in Brazilian literature: A prophetic discourse of alterity. Gainesville: University Press of Florida, 1995.

"Samuel Rawet na fronteira do real e do irreal: 'Dissemia', sexualidade e a consciência do/no mundo". In Waldman, B.; Amâncio, M (orgs.): NOAH/NOAJ, n. 16/17, pp. 285-298. São Paulo: Humanitas, 2007. 
WALDMAN, B. Entre passos e rastros: Presença judaica na literatura brasileira contemporânea. São Paulo: Perspectiva, Fapesp, Associação Universitária de Cultura Judaica, 2003.

. Linhas de força: Escritos sobre literatura hebraica. São Paulo: Humanitas, 2004. (Col. Judaica).

. 'Zona cinzenta: Entre a História e os espaços subjetivos em 'O lance de dados', de Samuel Rawet”. Ângulo, n. 120, pp. 70-79. São Paulo: Centro Cultural Teresa D’Avila, 2011.

WIRTH-NESHER, H. (org.). What is jewish literature? Philadelphia/Jerusalen: The jewish publication society, 1994.

YERUSHALMI, Y. H. Zakhor: História judaica e memória judaica. Rio de Janeiro: Imago, 1992. Trad. Lina G. Ferreira da Silva. (Bereshit). 


\section{Anexos}

\subsection{Anexo 1}

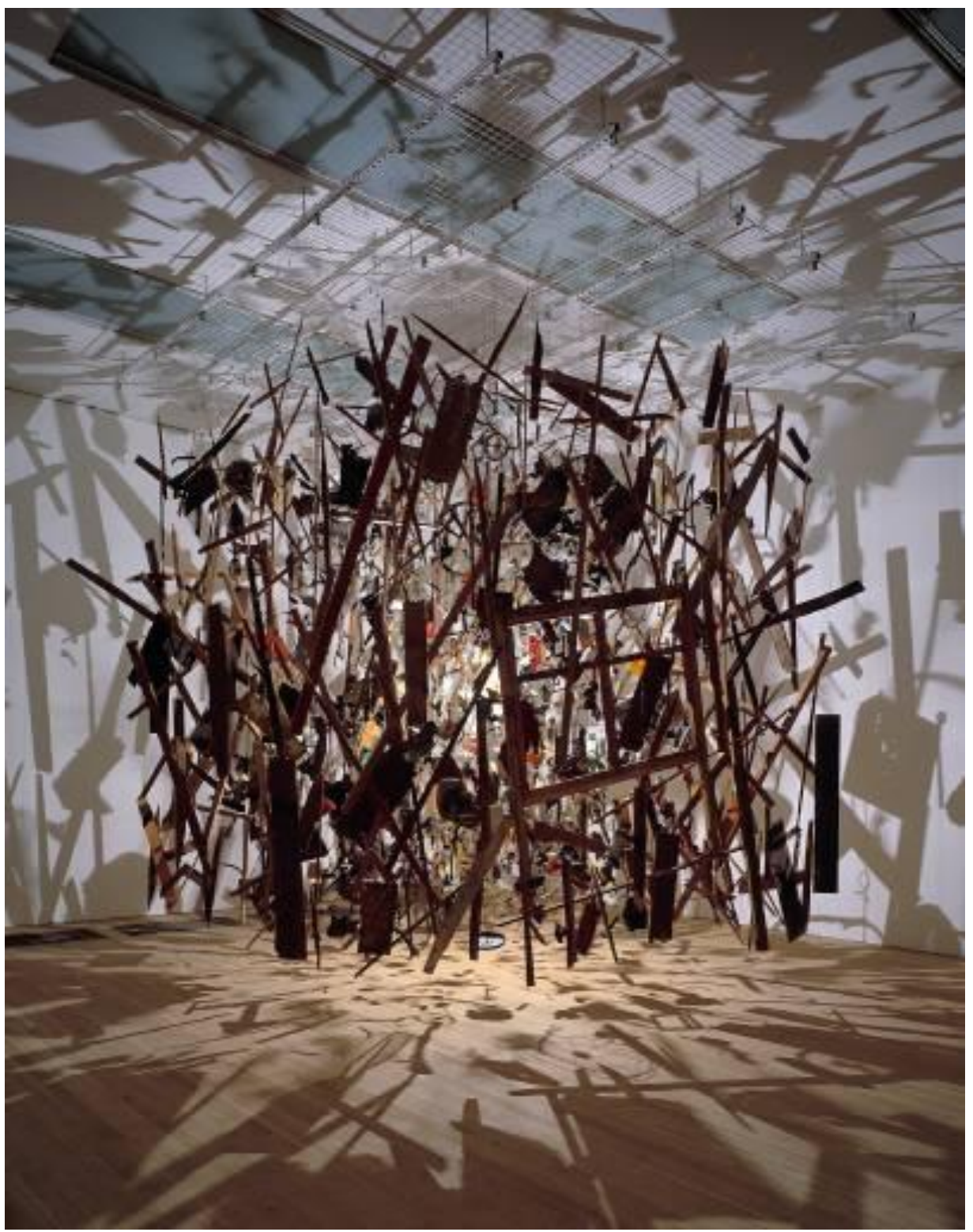

Figura 1. Cornelia Parker. Disponível em: http://www.tate.org.uk/art/artworks/parker-colddark-matter-an-exploded-view-t06949 


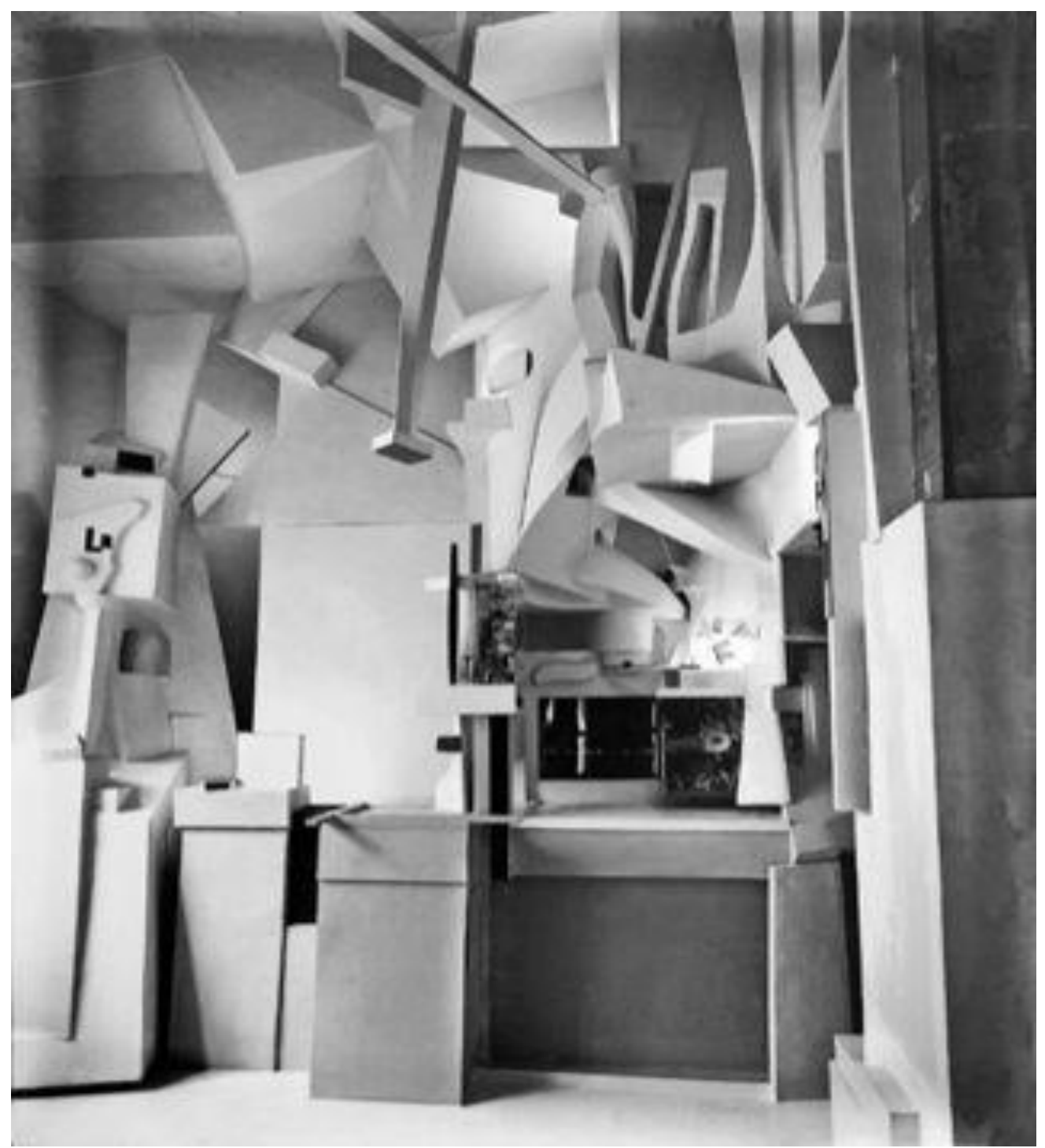

Figura 2. Merzbau de Kurt Schwitters (foto). Disponível em: http://www.sprengelmuseum.com/painting_and_sculpture/spaces/test-spaces.htm?bild_id=71919653. 
14.2 Anexo 2 - Subnúcleos de "Crônica de um vagabundo"

1. Entrada num cinema, filme já começado, a canção brejeira que o satisfaz;

2. O cão à cuja vista "um impulso induziu-o a encetar uma caminhada" (p. 215) e depois do qual [t]odos os incidentes passaram a funcionar como evocadores de seu mundo animal [...]”. Outros cães aparecerão no conto (cf. p. 229);

3. Entrada num bar, onde o personagem tenta vender alguns pertences que estão na maleta. Transação feita, o personagem sai do bar.

4. Abordagem por uma mulher (a prostituta). Sai em direção ao cais.

5. Um letreiro que costeia o morro fá-lo lembrar-se de "espadas flamejantes, mas já sem anjos" (p. 219). Tem início um fluxo de pensamentos sobre a reminiscência (ou talvez "estado permanente de lembrança"; "acontecimentos ainda presentes e que não esgotaram sua energia em potencial") e sobre o ódio (ou talvez "um pequeno incidente marginal, destituído de significado").

6. A visão de janelas que poderiam ser agrupadas em retângulos ordenados geometricamente, denotando regularidade e indiferença: "Era dentro dessa regularidade que caminhava [...] no mundo de linhas apenas" (p. 220).

7. Primeiro encontro com um velho, ao sentar-se num banco. Desenvolve-se uma série de imagens oníricas feitas de desejos, imaginação, lembranças e outros restos mentais.

8. Reencontro com o velho. Sua velhice faz o vagabundo pensar no passado. Vão, vagabundo e velho, para o quarto deste. Seu lema "O mundo é um bordel e eu sou uma puta" faz o vagabundo pensar.

9. Percebe que é noite, ao sair do prédio. Associa noite a temores.

10. Num balcão de bar, um garçom chama a atenção do vagabundo para um velho professor com duas mulheres. O vagabundo segue o grupo.

11. Encontro com o sujeito que lhe pede ajuda para limpar a velha.

12. Abordagem por dois tipos que tentam passar-lhe um golpe. Ele aceita o jogo. Tenta livrar-se do pacote entregue pelos dois.

13. Percebe o velho encontrado anteriormente, num "sussurro, e um esvoaçar de cabelos" (p. 229). Também percebe linhas, formas e ruídos urbanos.

14. Encontra-se com um sujeito do outro lado da rua. Ida a um hotel.

15. Vai até a praia; o percurso é detalhado. Encontra uma mulher, que lhe fala de um "Código da solidão". 
16. Quase-atropelamento por um caminha de feira. Recebe ajuda de um homem, que o leva para sua casa, onde encontra a esposa.

17. Emprego numa loja de roupas. Pedido de demissão.

18. Segundo reencontro com o velho, que lhe conta uma história sobre um homem, a quem se exigem "valores a respeitar, principalmente morais" (p. 239),

19. O vagabundo hospeda-se num outro hotel, Lá, ele sonha com um "homenzinho gordo e alourado" (p. 241). Os fatos anteriores repetem-se, um pouco alterados.

20. Acorda com o barulho no corredor: "flagrante de adultério". Procura dormir novamente, alheando-se propositadamente ao incidente. Sonha outra vez com a briga entre um bicheiro e um policial. Acorda com a chuva, tanto no sonho como na realidade.

21. Sente frio e levanta-se para fechar a janela. Arruma a maleta e sai do hotel.

22. Esperando a chuva cessar, pensa em partir como "um propósito definido, urgente inadiável" (p. 243).

23. Reencontro com o velho, que se confunde com o vagabundo. O velho tira-lhe a maleta e embarca. 